Board of Governors of the Federal Reserve System

International Finance Discussion Papers

Number 904

September 2007

\title{
The Role of China in Asia: Engine, Conduit, or Steamroller?
}

\author{
Jane T. Haltmaier, Shaghil Ahmed, Brahima Coulibaly, Ross Knippenberg \\ Sylvain Leduc, Mario Marazzi, and Beth Anne Wilson
}

NOTE: International Finance Discussion Papers are preliminary materials circulated to stimulate discussion and critical comment. References in publications to International Finance Discussion Papers (other than an acknowledgment that the writer has had access to unpublished material) should be cleared with the author or authors. Recent IFDPs are available on the Web at www.federalreserve.gov/pubs/ifdp/. This paper can be downloaded without charge from Social Science Research Network electronic library at http://www.ssrn.com/. 


\title{
The Role of China in Asia: Engine, Conduit, or Steamroller?
}

\author{
Jane T. Haltmaier, Shaghil Ahmed, Brahima Coulibaly, Ross Knippenberg \\ Sylvain Leduc, Mario Marazzi, and Beth Anne Wilson*
}

September 2007

\begin{abstract}
:
This paper assesses China's role in Asia as an independent engine of growth, as a conduit of demand from the industrial countries, and as a competitor for export markets. We provide both macroeconomic and microeconomic evidence. The macroeconomic analysis focuses on the impact of U.S. and Chinese demand on the output of the Asian economies by estimating growth comovements and VARs. The results suggest an increasing role of China as an independent source of growth. The microeconomic analysis decomposes trade into basic products, parts and components, and finished goods. We find a large role for parts and components trade consistent with China playing an important and increasing role as a conduit. We also estimate some regressions that show that China's increasing presence in export markets has had a negative effect on exports of some products for some other Asian economies, but not for other products, including those of the important electronic high-technology industry.
\end{abstract}

Keywords: China, engine, conduit, trade, integration, production fragmentation, displacement.

JEL classifications: E32, F10, F40

\footnotetext{
${ }^{*}$ Ahmed, Coulibaly, Haltmaier, Leduc, Marazzi, and Wilson are economists in the Division of International Finance of the Federal Reserve System. Knippenberg is a research assistant in the Division of International Finance. Mailing address: Division of International Finance, Board of Governors, Federal Reserve System, Mail Stop 24, Washington D.C. 20551, USA; email: jane.t.haltmaier@frb.gov. Tel.: (202)-452-2374; fax: (202)-736-5638. An earlier version of this paper was presented in April 2007 at an IMF conference on the Global Implications of China's Trade, Investment, and Growth. The authors would like to thank Matthew Bellfy and Scott Weaver for excellent research assistance and Jahangir Aziz, Caroline Freund, Karen Johnson, Michael Leahy, John Schindler, and participants of the IMF workshop for helpful comments. The views expressed in the paper are those of the authors and do not necessarily reflect those of the Board of Governors or the Federal Reserve System.
} 


\section{Contents}

1 Introduction 1

2 China as an Engine of Growth: Does the Rest of Asia Still Need an External Engine? Is it China? $\quad 4$

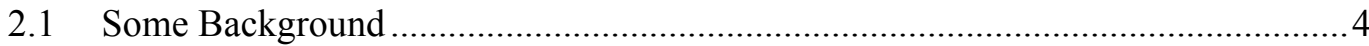

2.1.1 China Compared with Other Asian Economies ........................................ 4

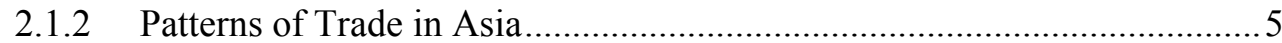

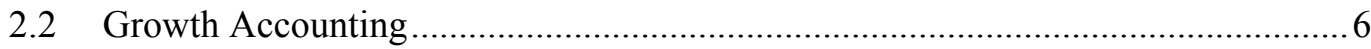

2.3 Aggregate Cross-Country Linkages .................................................................

2.3.1 Growth Comovements .................................................................... 7

2.3.2 Vector Autoregressions (VARs) ........................................................... 8

3 China as a Conduit of Growth: Is China the Endpoint of a Giant Asian Assembly Line? 12

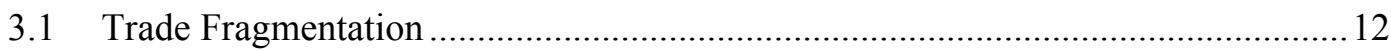

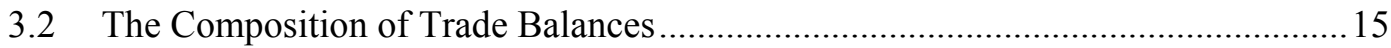

4 China as a Steamroller: How Is the Rest of Asia Adjusting to China's Growing $\begin{array}{ll}\text { Presence? } & 17\end{array}$

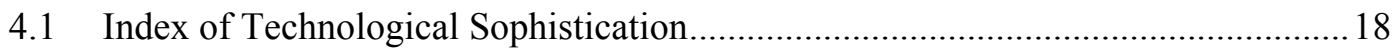

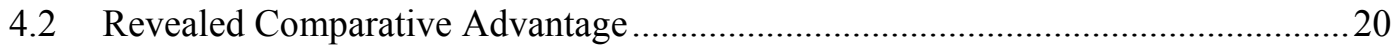

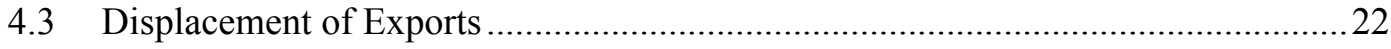

5 Conclusion $\quad 24$

\section{Boxes}

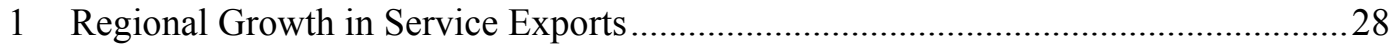

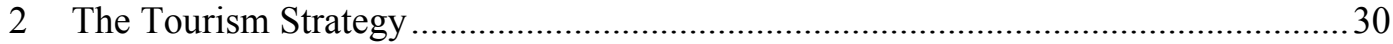

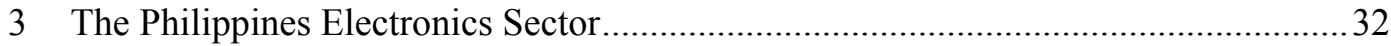

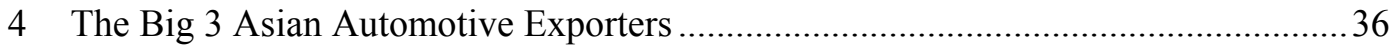

5 Foreign Direct Investment by Other Asian Economies in China ................................39 


\section{Appendix}

\section{Tables}

1 Variance Decompositions based on the estimated VAR ..........................................43

2 Share of Parts and Components in Exports by 1-Digit SITC Code.............................46

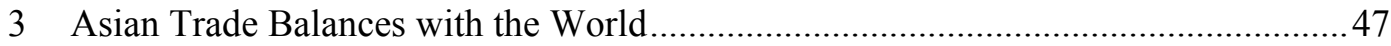

4 Asian Trade Balances with China vs. Rest of the World ..........................................48

5 Percentage of Total Regional Exports to the World by Tech Category .......................49

6 Distribution of Total Exports to the World by Tech Category ….................................50

7 Effect of Competition from China on Total Exports ...................................................51

\section{Charts}

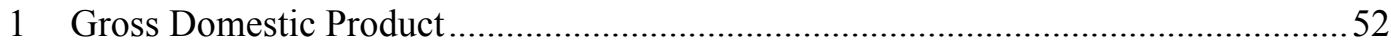

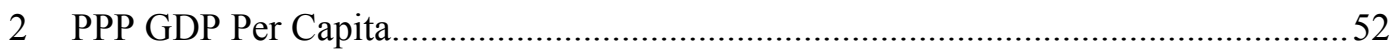

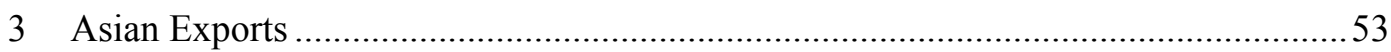

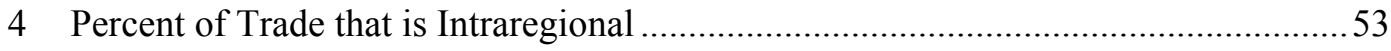

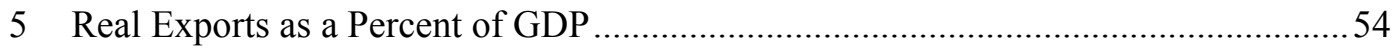

6 Percentage Point Contribution of Real Net Exports to GDP Growth..........................54

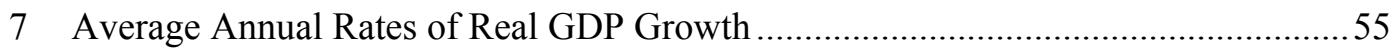

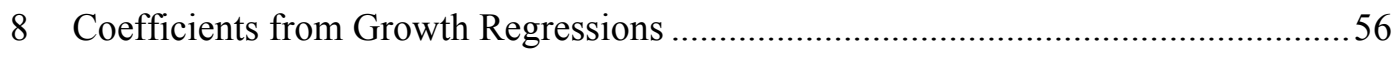

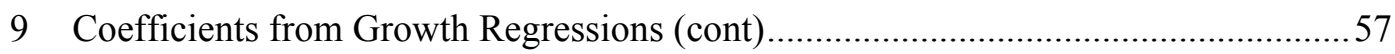

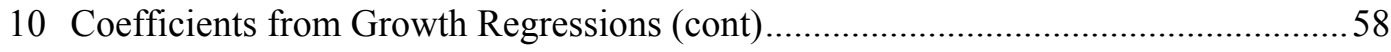

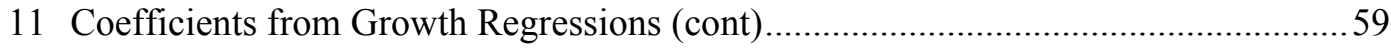

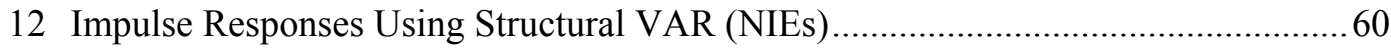

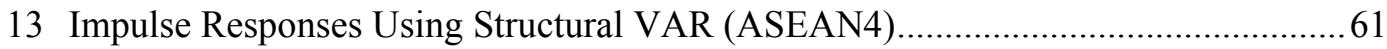

14 Parts and Components as a Percent of Exports of Manufactured Goods: 2005 ..........62

15 Parts and Components as a Percent of Imports of Manufactured Goods: 2005 ..........62

16 Parts and Components as a Percent of Trade in Manufactured Goods: 2005 ............63

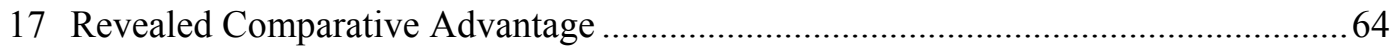

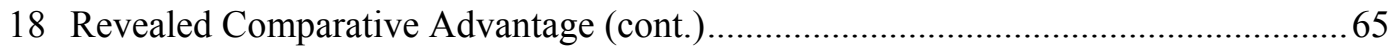




\section{Technical Notes}

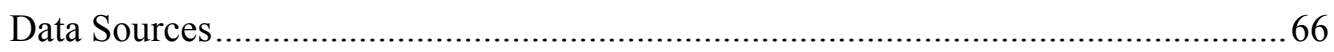

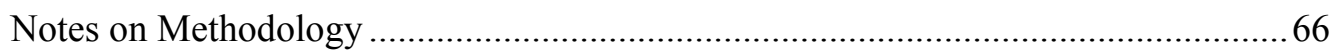

3-Digit Products by Technological Category: (SITC Rev.3) .....................................68

1-Digit Products by SITC: (SITC Rev.3) ................................................................ 72

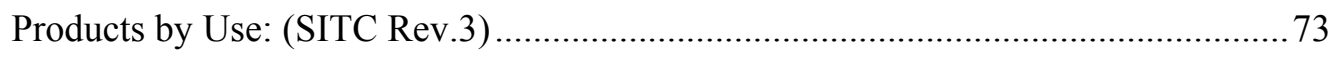




\section{Introduction}

Over the past two decades China has embarked on a process of development that has taken it at breathtaking speed from a poor, largely rural economy to a global economic force. The sheer size of its workforce and the speed of its transformation have posed enormous challenges for many countries around the world, but nowhere more than in its own backyard. The challenge is particularly important in Asia because most of these countries, including Japan, have tended to rely on the same export-led model of growth that China has used so successfully. From the point of view of smaller and in some cases more-developed Asian economies, it would be hard not to see China's low-cost labor force and enormous scope for economies of scale as a fearsome competitive threat. At the same time, however, China offers enormous opportunities as both a partner in production and a huge potential market of more than a billion consumers.

Ignoring China's growing presence in international markets is obviously not a possibility for the other Asian economies. Nevertheless, these countries do have several (not mutually exclusive) options for dealing with the rise of China:

(1) try to rely more on domestic demand and monetary policy to provide full employment and less on exports as either a trigger or a significant source of growth.

(2) try to seek out markets in China, perhaps in upscale consumer goods likely to be of interest to the burgeoning middle class. This strategy may also include increasing efforts to attract Chinese tourists.

(3) try to "piggy-back" on China's extraordinary success as a low-cost exporter by integrating production processes through trade fragmentation.

(4) try to avoid direct competition with China. This could involve looking for "niches" where China is less active and shifting export-oriented industries in those directions. This does not necessarily require any active government effort, as markets should tend to do this on their own. Trying to avoid competition with China in third markets can also involve shifting export-oriented production facilities to China, thus reducing investment at home.

In this paper, we use the available data, both macro and micro, to assess the extent to which any or all of these reactions are taking place. To the extent that these economies are reducing their reliance on exports, as suggested in (1) above, China would be a neutral force for growth in the region, as each economy would use policy to guide its own economy to reach potential output. In a 
simple growth accounting exercise using macro data we find that reliance on external demand as a source of growth has in fact fallen considerably in some of these countries. However, it is primarily the less-advanced economies in which this is the case, while net exports remain a very important source of growth in the more-advanced group, i.e., the Asian newly-industrialized countries (NIEs) and Japan. It is also noteworthy that the increased reliance on domestic demand in the lessdeveloped countries does not appear to have been reflected in lower rates of GDP growth in these countries.

To the extent that countries are able to use China as a market, as in (2), China may be becoming an independent engine of growth for the region. We examined both macroeconomic and microeconomic data to shed some light on this issue. Specifically, we estimated VARs that provide some evidence that China's demand for imports has become an important independent factor influencing growth in several Asian emerging economies. Korea, Singapore, Taiwan, and Thailand were found to be particularly responsive to movements in Chinese import demand. We also estimated rolling regressions that show a recent substantial increase in the comovements of GDP growth of many Asian economies with China, controlling for growth in the United States. In the micro data, we find some evidence that the more advanced economies have begun to sell more finished goods in China, but this is still quite limited.

To the extent that countries are partnering with China in production, as in (3), China is acting as a conduit of growth for the rest of the region, perhaps displacing some demand for finished product exports, but at the same time creating a new source of demand for parts and components produced in other countries. This arrangement of production uses China's relatively low-cost, lowskilled labor force to perform the less-demanding task of putting together the pieces built in other countries. Other papers have found substantial evidence that such "production fragmentation" is in fact taking place. This paper takes a fresh look at this issue using highly disaggregated trade data and finds that the degree may in fact be even larger than previous estimates have indicated. Our estimates differ from the earlier ones mainly because we have significantly extended the decomposition of trade - one of the main contributions of this paper. Interestingly, we also find that production integration with China appears to be far more important for the more advanced countries in the region than for the less-developed countries. It may not be a coincidence that the more advanced economies are also the ones for which external demand remains a very important source of growth. 
To the extent that China is taking market share from other countries, as in (4), China is acting somewhat like a steamroller, driving countries out of some areas of production, a process that may entail painful adjustments in the short run. However, in the longer run the principle of comparative advantage should dominate, and all countries should benefit as each country specializes in the products which it produces relatively most efficiently. We find some evidence that this is in fact taking place. For instance, the trade data show shifts in relative comparative advantage that suggest that some countries are attempting to move production to areas where they face less competition from China. A prime example is increased comparative advantage in auto production by auto giants Korea and Japan. A cautionary note, though, is that recent data suggest that China is on the move in these industries as well, suggesting that these countries may soon need to seek other niches.

Additional evidence of the potential "crowding out" effect of China on other emerging Asian exports is provided by the results of regressions of changes in highly disaggregated categories of exports on a number of variables, including China's share of world exports in each category. We find that increases in China's market shares of low- and mid-technology products have in fact had a significant negative impact on exports from some other East Asian economies. However, we do not find such an effect in the important high-technology category, suggesting that integration may be working more effectively there. Our work in this area represents an extension of the analysis in Ahearne et al (2006), which focused on changes in market shares of exports from various emerging Asian economies to just the United States.

The balance of the paper is organized as follows. Section 2 begins with some background information on the relative size of the Asian economies we have included in our analysis and on how patterns of trade in the region are changing. It then uses macro data to examine the extent to which reactions to China in the region fall into categories (1) and/or (2) above. This includes the growth accounting exercise that documents the importance of net exports to GDP growth in these countries. It then analyzes the cross-country linkages using the VAR model and the rolling regressions. Section 3 primarily examines the role of China as a conduit of industrial growth for the region. We first describe our trade dataset, then look at the structure of exports in the region from various angles and detail the extent of product fragmentation. This section also provides some further insight into China's role as an independent engine of growth, by looking at the extent to which China's imports of finished goods from other countries in the region have changed. Section 
4 looks at China's role as a steamroller, including the changes in comparative advantage and the results of the regressions of changes in trade on the size of China's market share of an industry. We also look at the extent to which production shifting may be having a negative effect on investment in some of the other countries in the region. Section 5 concludes.

Our main conclusion is that China is largely a positive force for economic growth in the rest of the region, particularly for the advanced economies, but that it is still more of a conduit than an engine. This suggests that the region remains vulnerable to economic cycles in industrial countries. There is also some evidence that China is acting as a steamroller in some industries, pushing some of its smaller competitors out of the way. Nevertheless, it should be noted that economic growth in the region remains higher than in most of the rest of the world, including other emerging markets. This suggests that despite the presence of an increasingly powerful player in Asia and the world economy, the other countries are managing to find ways to stay in the game.

\section{China as an Engine of Growth: Does the Rest of Asia Still Need an External Engine? Is it China?}

In this section we first look at some implications of the relative size of the Chinese and other Asian economies and at how patterns of trade among them are changing. We then consider the following questions: How reliant are key emerging Asian economies on external demand and has this reliance changed over time? In other words, to what extent do these countries still need an external engine of growth? We also ask: What is the relative importance of China and the United States as a source of external demand for the rest of emerging Asia and has this relationship changed over time? If external demand remains key to growth in the region, and if China is becoming a stronger engine of that growth, we would expect to see that Chinese economic growth has had a significant independent impact on the other economies in recent years.

\subsection{Some Background}

\subsubsection{China Compared with Other Asian Economies}

As shown in Chart 1, China is the second-largest economy in Asia, behind Japan, in U.S. dollar terms. This was also true in 1990, although barely; at that time the Chinese economy was only about 13 percent the size of Japan's, whereas in 2006 it was 60 percent as large. In contrast, 
as measured by PPP per capita (chart 2), the Chinese standard of living remains only a fraction that of the advanced economies of both the NIEs and Japan. However, China now compares much more favorably with the less-developed Asian economies, as sixteen years of rapid growth between 1990 and 2006 have brought its standard of living well above those of India, Indonesia, and the Philippines, all of which had higher levels of PPP GDP per capita than China in 1990. Nevertheless, China's standard of living is still below that of Thailand, although it is getting close, and it is further below that of Malaysia.

There are at least two important implications of these data. First, China, despite its remarkable economic performance of the past two decades, is still a poor country. This is consistent with its relatively low labor costs. However, it is rapidly catching up and has already surpassed some of its less-developed Asian neighbors. This may suggest that China's competitive edge may begin to erode. There is in fact some evidence that this is already happening, as farm incomes in China have been rising, decreasing the attraction of moving to the city for a poorly-paid factory job. There are reports that manufacturing firms have needed to raise wages and improve benefits to fulfill their labor needs, and there are also reports of firms moving operations to countries such as Vietnam to take advantage of even lower-cost labor. Secondly, the contrast between China's rank in the area in PPP terms with its rank in dollar terms illustrates the vast scale of its economy compared with the others in the area. This suggests that even without rock-bottom wages China stands to be able to exploit economies of scale that may well remain out of reach for the other economies in the region.

\subsubsection{Patterns of Trade in Asia}

As seen in Chart $3^{1}$, goods exports from Asia (defined as Japan plus emerging Asia) nearly quadrupled between 1990 and 2005, increasing from $\$ 725$ billion to $\$ 2826$ billion. (This paper focuses mainly on trade in goods, which is much larger than trade in services and for which considerably more detailed data are available. For a brief discussion of trade in services in the region, see Box 1. Box 2 looks at a specific category of services trade, tourism.) Although in 1990 the value of exports to destinations outside of the region was greater than the value of intra-regional trade, by 2005 they were about the same size, suggestive of greater integration of production across the

\footnotetext{
${ }^{1}$ We have combined exports for China and Hong Kong because of the substantial amount of Chinese trade that passes through Hong Kong. For the other countries, we have added together their exports to China and Hong Kong.
} 
region. Nevertheless, as shown in Chart 4, changes in trade patterns have not been uniform across the region. Although the total proportion of Asian trade that was intra-regional rose from 41 percent in 1990 to 52 percent in 2005, it actually dropped somewhat for China/Hong Kong, as China became more of a force in global trade. In contrast, intra-regional trade rose for all of the other countries in the region. Even for the larger and more diversified Korean and Japanese economies, intra-regional trade now accounts for nearly half of their exports, up considerably from 1990. In sum, these data are suggestive (although not conclusive evidence) of greater production integration within the region, a topic to which we return later.

\subsection{Growth Accounting}

Just how important is trade to the overall economies in the region? As shown in Chart 5, the ratio of real exports to GDP is sizable for most of the emerging Asian countries. It is interesting that China actually falls toward the lower end of the scale at a still-high 40 percent, reflective of the vast size of its economy. The very high ratios for Hong Kong (about 180 percent) and Singapore (nearly 250 percent) are partly due to their role as trade hubs. The ratio is lower for India (20 percent), and Japan (14 percent). For the United States, shown for comparison, the ratio is considerably lower at 11 percent. The chart also illustrates the extent to which the importance of exports has been rising in recent years for all of these countries, in some cases quite substantially.

Chart 6 shows the average contribution of real net exports to GDP growth over two periods, 1995-2000 and 2000-2006. ${ }^{2}$ In the first period, the net export contribution ranged from small amounts in India and Japan to around 4 percentage points in Malaysia and Thailand. In China, the contribution of net exports was 1.8 percentage points. The contributions were also sizable in Hong Kong, Korea, and Indonesia. However, in the second period, a more defined pattern emerges. In particular, the contribution of net exports is large for all of the newly industrialized economies (Hong Kong, Taiwan, Korea, and Singapore), ranging from 1.5 percentage points in Korea to 4.6 percentage points in Singapore. In contrast, the contribution of real net exports to growth is small or negative in the second period for the less-developed emerging Asian economies (ASEAN-4 and India). Nonetheless, as shown in Chart 7, GDP growth rates during this period were quite respectable in all of the latter group of countries, and were in some cases higher than in the earlier

\footnotetext{
${ }^{2}$ The data for China and India are only through 2005, as this is the last date for which they have expenditure by component.
} 
period. Thus, not all of the countries appear to be dependent to the same degree on net exports as drivers of growth. Somewhat paradoxically, it is the less-developed countries in the region that are showing less dependence on net exports, at least in an accounting sense. This of course does not rule out the possibility that exports are an important trigger of growth, with the paucity of the net export contribution a result of concurrent high growth in imports. However, it does suggest that domestic demand is playing an increasingly important role in these countries.

\subsection{Aggregate Cross-Country Linkages}

\subsubsection{Growth Comovements}

If China were becoming more of an engine of growth for Asia, we would expect to see changing patterns of cross-country linkages in economic growth rates at the aggregate level. In particular, keeping fixed the growth rates of traditional engines of growth for the Asian economies, such as the United States, we would expect to see an increased correlation of growth with China.

There is a fair amount of literature on how cross-country linkages in growth have shifted over time. Much of this literature pertains to the experience of industrialized countries - see for example, Doyle and Faust (2005). Some authors, such as Kose, Prasad, and Terrones (2003), have also included the experience of developing countries, including those in Asia, to look at how increased trade integration has affected the synchronization of business cycles across countries. However, that work uses data only through 1999 and is, therefore, not recent enough to take into account the full effects of the emergence of China.

We used rolling regressions to estimate the contemporaneous correlation of each country's real GDP growth with U.S. and/or Chinese real GDP growth. ${ }^{3}$ The regressions were estimated over a ten-year period, starting in 1970:Q1-1980:Q1 and moving forward by one quarter, with the last regression ending in the fourth quarter of 2006. For each country we ran three regressions: one with both U.S. and Chinese GDP growth on the right-hand side, one with just U.S. growth, and one with just Chinese growth. Because of difficulties seasonally adjusting the data for some of these countries, especially China, which does not have an official quarterly real GDP level series, we used four-quarter growth rates in the regressions. Standard errors were calculated using the Newey-West

\footnotetext{
3 Ahearne et al (2006) also run somewhat similar regressions. However, their work focuses on comovements of Chinese and other emerging Asian economies' exports, rather than the growth comovements we consider here. They also do not run rolling regressions, but instead look at a one-time structural break in the comovement in 2001, the year of China's accession to the WTO.
} 
method. These regressions were done for Hong Kong, Taiwan, Japan, Korea, Singapore, Malaysia, India, Indonesia, the Philippines, and Thailand.

The results we report are for the regressions that included both U.S. and Chinese growth. The results for the other regressions are not materially different. The reported results are shown in charts 8-11, which plot the coefficients for China and the United States, along with 95-percent confidence bands. The results suggest that in recent years Chinese growth has become considerably more important for most countries. This pattern is most striking for Thailand, where the coefficient on Chinese growth is insignificant until around 2000, when it rises to about 1.7 and becomes significant, before falling back to 1.3 by the end of the sample. Over the same time period the coefficient on U.S. growth in the Thai equation becomes negative and insignificant, after having been positive and significant earlier in the sample. The other less-developed countries, including India, all also show a substantial increase in the coefficient on Chinese growth in recent years, and it becomes significant in most cases. However, the results for the coefficient on U.S growth differ among countries. For Malaysia and India the coefficient becomes negative and insignificant in the late 1990s. It then becomes positive again for Malaysia, but remains insignificant. For the Philippines and Indonesia, the coefficient becomes positive and significant in the second half of the 1990s, but it then falls off again.

The more developed countries also show an increase in the coefficient on Chinese growth at the end of the sample, although it is not significant for Hong Kong and Korea. The coefficient on U.S. growth also generally increases at the end of the sample, although it is significant only for Singapore and Taiwan.

By and large, these results suggest that Chinese growth has become more important for the region, while U.S. growth has become less important, particularly for the less-developed countries. In contrast, U.S. growth remains quite important for Singapore and Taiwan, and to a lesser extent for Hong Kong, but it appears to matter much less for either Korea or Japan.

\subsubsection{Vector Autoregressions (VARs)}

The changing patterns of growth comovements are interesting and informative and lead us to try to more specifically identify U.S. and Chinese demand shocks for the goods of the other emerging Asian economies. We do so through a VAR model where we assess the relative contributions of shocks to U.S. import demand and shocks to Chinese import demand for growth in various emerging 
Asian economies from 1993:Q2 to 2006:Q4, the period over which China has made great strides in its degree of trade openness. ${ }^{4}$

Specifically, we estimate a three-variable structural VAR for each of several major emerging Asian economies, including the following variables: domestic real GDP growth, growth of U.S. real imports from the country, and growth of Chinese real imports from the country. To obtain U.S. real imports from a given emerging Asian economy, nominal imports in U.S. dollars from that economy are deflated by the U.S. overall import price index. Chinese imports from a particular emerging Asian economy include imports of both mainland China as well as Hong Kong, since it can be difficult to separate direct trade with Hong Kong from indirect trade with mainland China occurring through Hong Kong. Because of a lack of an appropriate import price deflator for China, we use the producer price index (PPI) as a proxy. Chinese nominal imports are deflated by the Chinese PPI and those for Hong Kong by the Hong Kong implicit deflator for imports.

To identify the U.S. demand and Chinese demand shocks a Cholesky decomposition based on the ordering U.S. real imports, Chinese real imports, and domestic growth is used. Note that according to the Cholesky decomposition, a variable is contemporaneously affected by those variables coming before it in the ordering and contemporaneously influences but is not contemporaneously influenced by those variables coming after it in the ordering. This ordering makes some sense because the emerging Asian economies can be considered to be small open economies, which would take as given U.S. and Chinese incomes and the world prices of the goods they export - which would be the main determinants of U.S. and Chinese demand for their goods. Given the small open economy assumption, we also make the system block recursive with even the lagged values of domestic growth not feeding back into the U.S. and Chinese variables.

We estimate the reduced form VAR (with the appropriate choice of lag length based on statistical criteria) and then retrieve the structural VAR using the identification assumptions. We compute, for each country, dynamic responses of domestic growth to positive shocks to growth of U.S. and Chinese imports (impulse responses). These are then cumulated to give the effects over time on the level of domestic output. The responses of the level of domestic output to a one standard-deviation shock to U.S. and Chinese import growth (which, of course, are also shocks to exports to the U.S. and China from the viewpoint of these countries) are shown in chart 12 for the NIEs of Korea,

\footnotetext{
${ }^{4}$ However, the sample size requirement precludes us from examining structural breaks in the importance of these shocks.
} 
Singapore and Taiwan. Their 90 percent confidence bands based on Monte Carlo simulations (5,000 replications) are also shown.

As can be seen from the left hand side panels in the chart, not surprisingly, a one-standard deviation shock to the exports of these countries to the United States has a significant positive effect on domestic output for each of these three economies. ${ }^{5}$ For example, after a lag of one quarter, the effect on Korean real GDP is about 2 percent at an annual rate, on real output in Singapore is about 3 percent, and on real output in Taiwan is about 1 percent. Interestingly, the right hand panels show that a one standard-deviation shock to exports to China has about an equal initial effect, if not slightly bigger, as the U.S. shock on output in Korea, Singapore, and Taiwan. ${ }^{6}$

The effects of the same type of shocks on the ASEAN-4 economies are shown in chart 13 . The effects of U.S. demand shocks on domestic GDP are clearly evident for Indonesia and Malaysia and even for Thailand, although with a lag. However, the Chinese demand shock does not appear to have a statistically significant effect on domestic output in the ASEAN-4, except for Thailand. ${ }^{7}$

How much of domestic growth fluctuations in these seven countries can be explained by the U.S. and Chinese demand shocks? The answer depends not just on the size of the impulse responses when given size shocks occur (shown in charts 12 and 13), but also on how often and, on average, what size shocks hit the economy. The variance decompositions, which measure the percentage of the forecast error variance of domestic output growth at various forecast horizons that is attributable to each of the shocks, provide the answer.

The results for the variance decompositions are reported in table 1. External shocks originating in the United States and China are quite important for these seven emerging Asian economies. Together, the two shocks account for about 20 percent to 50 percent of the forecast error variance of domestic output growth at a 1-4 quarter horizon in the NIEs of Korea, Singapore, and Taiwan. In the ASEAN-4, they account for less, from about 5 to 30 percent.

Looking at the two shocks individually, U.S. shocks account for up to 25 percent of the forecast error variance of growth in Korea and Singapore, but only up to about 12 percent of growth in Taiwan. Chinese shocks also account for about up to 25 percent of domestic growth fluctuations

\footnotetext{
${ }^{5}$ Note that each country has a different empirical VAR model, so the size of a one standard-deviation shock to growth of exports to U.S. differs from country to country. The size of the shock ranged from 10 percentage points of annual growth to 21 percentage points of annual growth.

${ }^{6}$ The size of a one-standard deviation shock to growth of exports to China ranged from 16 percentage points of annual growth to 37 percentage points of annual growth. In each case, the size of the China shock was greater than the U.S. shock and this was especially true of the ASEAN4 countries.

${ }^{7}$ Note that Thailand is the country among the ASEAN-4 with closest geographical proximity to China.
} 
in Korea and Singapore, and account for up to 30 percent of growth fluctuations in Taiwan, significantly more than U.S. shocks. For Indonesia, Malaysia, and the Philippines, Chinese demand shocks are not a major driving force behind domestic growth fluctuations, but U.S. demand shocks are. The case of Thailand is more like the NIEs with both U.S. demand shocks and Chinese demand shocks being important, with the latter more significant than the former.

Two main conclusions can be made from the structural VAR analysis. First, external shocks have been quite important over the past fifteen years or so for domestic output fluctuations in our sample of emerging Asian economies. Second, over the same period, Chinese demand shocks have been at least as important, if not more, as shocks originating in the United States in explaining domestic growth fluctuations in Korea, Singapore, Taiwan, and Thailand. In contrast, Chinese demand has not played a significant part in explaining the growth of Indonesia, Malaysia, and the Philippines.

It might be argued that the shock to exports to China in the above VAR analysis overestimates the extent to which China serves as a direct engine of growth for the rest of emerging Asia because these exports to China might represent derived demand. In other words, to a large extent, China may only import intermediate goods from these other emerging Asian economies in order to satisfy final external demand arising from the United States and other industrial countries.

Although we will consider this issue in much more detail later using micro trade data, we also experimented with an augmented VAR of four variables which adds the variable: real exports from China (including Hong Kong) to the United States. This variable was placed second in the causal ordering in the new VAR - that is, after real exports to the United States from the particular country whose model we are considering and before real exports of that country to China. If the added variable takes over in importance from real exports to China, this would be consistent with the "derived demand" hypothesis.

None of the conclusions reached from the earlier VAR are overturned with the augmented VAR; in particular, economies for which exports to China were important before remain so. But the augmented VAR does give some additional insights. Real exports to the United States from China are significant in explaining domestic economic growth in some of the emerging Asian economies, most notably Singapore, Malaysia, and Thailand. For two of these economies, Malaysia and Thailand, exports to China were not important in the first place. This suggests that the impact of real exports from China to the United States on these countries' output growth in some cases may in 
part be representing such factors as the effects of export-oriented foreign direct investment from these countries to China.

\section{China as a Conduit of Growth: Is China the Endpoint of a Giant Asian Assembly Line?}

The macro evidence presented in the previous section is consistent with an increasing effect of the Chinese economy on output and import fluctuations in emerging Asia, even when controlling for growth in the United States. This is suggestive of a greater role for China as an engine of growth rather than just a conduit for U.S. demand. However, it is not conclusive evidence, as the tighter correlation could also be consistent with greater integration of production through trade fragmentation, particularly if this were reflected in a higher degree of time synchronization within the region than with trading partners in other parts of the world. To look more closely at the extent to which China represents an independent engine of growth rather than acting as a conduit of industrial country demand, we turn now to an analysis of the micro trade data. As one of the main contributions of the paper, we first provide a comprehensive decomposition of exports and imports into three categories: basic goods and construction materials (BP), parts and components (MPC), and finished manufactured goods (MFG). Other papers have done only partial decompositions. Key features and implications of the parts and components trade are then discussed.

\subsection{Trade Fragmentation}

Anecdotal evidence suggests that trade fragmentation or vertical integration has become increasingly important in emerging Asia. In particular, China's low-cost labor force is thought to offer an attractive endpoint in a production chain that may stretch across one or more other economies at varying stages of development. In this process, Asian countries other than China specialize in production of intermediate goods in which they have comparative advantages and export them to China (sometimes through Hong Kong) for assembly and re-export. To the extent that this is the case, exports to China from other countries in the region should be highly concentrated in the parts and components categories. At the same time, Chinese exports should become more concentrated in finished goods. 
Distinguishing parts and components trade from other types of trade needs to be done at the 5-digit product level, as even the 3-digit level does not classify products finely enough. For example, SITC 727 consists of food processing machines and parts. SITC 72711, 72719, and 72721 include different types of food processing machines, an example of finished goods, while SITC 72722 and 72729 include the parts and components for these machines. Unfortunately, not all of the categories can be separated so neatly. The separation is somewhat easier for SITC 7 (machinery and transport equipment) and SITC 8 (miscellaneous manufactured articles), as was done in Athukorala (2003) and Athukorala and Yamashita (2006) than for SITC 5 (chemicals and chemical products) and SITC 6 (manufactured goods). Although Athukorala and Yamashita noted that SITC 5 and SITC 6 also have significant parts and components categories, they did not attempt a separation for them. We have largely followed Athukorala and Yamashita's classification for SITC 7 and 8, although we have made some modifications. For instance, we moved ball bearings, piston engines, and various kinds of pumps from finished goods to parts and components. ${ }^{8}$

With the exercise of some judgment, we have also extended the separation to SITC 5 and 6. In addition, we examined SITC 0-4 and found a few categories that are classifiable as parts and components, i.e. synthetic fibers (this includes all of the 5-digit sub-categories of two 3-digit industries). The rest of the trade in SITC 0-4 is unlikely to play a role in trade fragmentation. We have classified these group as basic products and construction materials. A full description of each category is provided in the appendix.

Not surprisingly, our comprehensive decomposition of trade results in much higher estimates of the importance of trade fragmentation than was found in earlier studies, although direct comparisons are complicated by the fact that different studies not only measure parts and components differently, but also compare them to different aggregates. For instance, Ng and Yeats (1999) measure production fragmentation by trade in parts and components of SITC 7 and 8 using SITC Revision 2. They found that this measure of parts and components constituted 20 percent of total East Asian exports of manufactured goods in industries in SITC 6 through 8 (excluding 68) in 1996. However, this ignores the substantial amounts of parts and components that we have identified for SITC 6. Using the more detailed SITC Revision 3, Athukorala (2003) calculated that parts and components accounted for 28 percent of East Asian manufacturing exports in SITC 7 and 8 in 2003.

\footnotetext{
${ }^{8}$ Conversely, we decided that artificial body parts should more properly be categorized as finished goods.
} 
As shown in table 2, our more comprehensive definition of parts and components indicates that these products accounted for over 40 percent of total Asian exports (the top half of the table) and nearly half of exports of manufactured goods (defined as the sum of parts and components and finished goods, our second and third categories described above, shown in the lower half of the table) in 2005. The reason that our measure is so much larger than in other studies is that SITC 5 and 6 in fact have the largest proportions of parts and components. SITC 8, in contrast includes a very small fraction of parts and components.

For the region as a whole, exports of parts and components constituted 46.5 percent of total exports of manufactured goods in 2005, down a little from 1995. However, the decline was mainly due to an increased weight for China, where parts and components are a smaller share of exports, although even there the share rose over the ten-year period. For the rest of the region, the export share of parts and components was already high at 50 percent in 1995, and it rose a little further, to 51 percent in 2005. This share is a full ten percentage points higher than that for the rest of the world, supporting the idea that trade fragmentation is more important in the Asian region than in other parts of the world.

As illustrated in Chart 14, China is very much an outlier in the region in terms of the percentage of exports that are parts and components. For trade with the entire world (the dark blue bars), this category comprises less than 30 percent of China's exports, but it is about 50 percent of exports for Japan, India, Korea, Malaysia, and Thailand, 60 percent for Taiwan and Singapore, and nearly 70 percent for the Philippines. The importance of trade fragmentation with China is supported by the fact that the percentages of parts and components in exports to China (the light blue bars) are considerably higher than for exports to the rest of the world (the violet bars), with the proportion for exports to China ranging from about 60 percent for Japan, Thailand, and Indonesia to over 80 percent for India and the Philippines.

The picture is considerably different for imports, shown in Chart 15 . The percentage of China's imports of manufactured goods that are parts and components was nearly 70 percent in 2005, a little higher than for most of the other countries in the region, although lower than that for the Philippines. The rates for Japan, which is at a much higher level of development, and India, which, as noted earlier, is generally less integrated with the region, are considerably lower than the rest. The fact that many of these countries import as well as export large amounts of parts and components may suggest that production integration arrangements in the region are not confined 
to trade with China. However, as illustrated in Chart 16, which compares the percentage of parts and components in exports and imports in total trade for each country, the discrepancy for China is far larger than for any of the other countries, supporting the idea that China is more often than not the endpoint of the Asian assembly line.

\subsection{The Composition of Trade Balances}

The importance of trade in intermediate vs. final goods is further illustrated by an examination of trade balances. As shown in the second column of table 3, the Asian region's trade surplus with the world was $\$ 225$ billion in 2005, more than three times its 1995 size. This surplus was fairly widely shared among countries, with only Thailand, the Philippines, and India running trade deficits. Japan alone accounted for about a third of the region's surplus in 2005, although its surplus declined significantly over the ten-year period.

Consistent with China's role as an assembler, its $\$ 94$ billion surplus with the world in 2005 was entirely in manufactured finished goods (MFG), where the surplus ballooned from $\$ 46$ billion in 1995 to over $\$ 300$ billion in 2005. Over the same period, China's trade deficits in the other categories expanded. In contrast, the rest of the region (excluding India, which had a deficit in all three categories) had large surpluses in both MFG and MPC in 2005, along with a large deficit on basic products.

However, trade patterns vary widely by country. The more advanced economies of Japan, Korea, Taiwan, and Singapore all had surpluses in 2005 in both MFG and MPC, along with deficits in BP. In contrast, most of the less-advanced countries had deficits in MPC along with surpluses in MFG. (Indonesia was the only exception with small surpluses in both categories.) This suggests that the more-advanced countries are the primary beneficiaries of China's role as a conduit, while the other countries may in fact be playing an assembler role more similar to that of China, although on a smaller scale.

Table 4, which breaks down the region's trade with China/Hong Kong vs. the rest of the world, provides further evidence that not only is China still primarily a conduit rather than an engine for growth in the region, and affirms that this role is more important for the more advanced economies in the region. Asia outside of China and Hong Kong in the aggregate had a large surplus with China in 2005, double the 1995 level. Nearly all of this surplus was in parts and components, along with a much smaller surplus in basic products, and a small deficit in finished goods. Once again, the 
pattern of trade differs sharply across countries. Nearly all of the region's surplus with China, both overall and in MPC, was accounted for by the more advanced economies. This group also had a small net deficit with China in MFG, although Korea and Taiwan both had small surpluses (which may suggest the beginnings of an increased role of China as an engine of growth). With the exception of India, which had a small deficit with China, the less-advanced group generally had small surpluses, the largest portion of which was in basic products. This group also had a small overall surplus in parts and components, mainly accounted for by Malaysia and the Philippines, and a deficit in finished goods, mainly accounted for by India.

As shown in the lower part of the table, the region's pattern of trade with the rest of the world is quite different from its trading relationship with China. In addition to the fact that the region had a very large deficit with the rest of the world in basic products (only Indonesia and Malaysia had surpluses in this category), it also had a very large surplus in finished goods. Although it also had a surplus with the rest of the world in parts and components, it was much smaller than its surplus with China in this category, consistent with the greater amount of trade fragmentation within the region than without. Once again, there were substantial differences across countries, including significant differences within the more and less-advanced groups. In particular, Japan Korea, and Singapore all had surpluses with the rest of the world in both finished goods and parts and components, along with deficits in basic products. However, Korea's surplus categories were not large enough to offset its basic products deficit, while Taiwan had deficits in all three categories. These two countries are thus dependent on trade with China to generate a surplus. For the lessadvanced economies, only the commodity-exporters Malaysia and Indonesia had surpluses with the rest of the world, although all them except India had surpluses in finished goods, while all but Indonesia had deficits in parts and components. This again suggests that these countries are more like China than they are like the more advanced economies in the region.

In sum, the evidence suggests that China remains largely an importer of inputs into its assembly trade in regard to the rest of Asia, and that it is mainly the more advanced economies that are feeding the Chinese assembly line. The less advanced countries appear to be gaining little net benefit from trade with China, although there are signs that this is changing. For instance, the Philippines showed a small surplus in parts and components trade with China in 2005, up from nearly balanced trade in 1995. This may suggest that the Philippines is moving into a role similar to that played by the advanced countries. (Box 3 explores recent developments in the Philippines 
economy in more detail.) However, other than the small surpluses in finished goods for Korea and Taiwan, there is very little evidence that China has become a source of final demand for the region.

\section{China as a Steamroller: How Is the Rest of Asia Adjusting to China's Growing Presence?}

The evidence shown in the previous section suggests that China has become an important partner in production with the more advanced Asian economies, but that it is providing little net stimulus to the rest of the region. However, as noted in the introduction, ignoring the Chinese giant is hardly an option for its closest neighbors. Like a massive rock dropped into a placid lake, China is clearly sending ripples (if not waves) in all directions, with the largest impact in the immediate region. The purpose of this section is to use our dataset to assess the effect of China on the region by looking at changes in export structure. In particular, we consider three aspects of changes in export structure: changes in technological sophistication, changes in revealed comparative advantage, and by-product displacement of exports as a result of competition from China. We look at export structure in terms of the technological classification introduced by Lall (2000) (as was done in Lee and Plummer (2004)). This taxonomy includes ten categories, which are detailed in the appendix: primary products (PP); agricultural resource-based manufactures (RB1); other resource-based manufactures (RB2); low-technology textile manufactures (LT1); low-technology manufactures of other products (LT2); medium-technology automotive products (MT1); medium-technology process goods (MT2); medium-technology engineering products (MT3); high-technology electronic products (LT1); and other high-technology products (LT2).

The magnitude of China's rise in the region is illustrated table 5, which shows each country's percentage of the region's total exports by technological category. As shown on the far right, China's total merchandise exports increased from 11 percent of the region's exports in 1995 to 27 percent in 2005, as they quintupled in value. In 2005 China accounted for 50 percent of the region's exports of textile products, almost 40 percent of other low-tech manufactures, and almost 30 percent of electronic high-tech. China has come to dominate regional exports even in several categories which comprise only small proportions of its own exports. For instance, China was the largest exporter in the region in dollar terms in 2005 of primary products, which (as shown in table 6 ) accounted for only $4 \frac{1}{2}$ percent of its own exports, as well as of agricultural resource-based 
manufactures ( $3 \frac{1}{2}$ percent of its exports).

The data in table 6 also make clear the extent to which China has moved up the value chain over the past ten years. In 1995, nearly half of China's exports were of low-tech textile and other manufactures, more than 20 percent were of primary products and resource-based manufactures, and 13 percent were of high-tech products. However, by 2005, the proportion of China's exports in the high-tech categories had risen to 33 percent, while the share of low-tech manufactured exports had fallen to 32 percent. Primary and resource-based products accounted for about 13 percent of exports in 2005 .

\subsection{Index of Technological Sophistication}

In order to compare the technological structure of exports across countries and across time, we introduce a simple index of technological sophistication (ITS), shown on the far right of table 6 , that is higher the greater the percentage of each country's exports in the more technologically sophisticated categories. The index is constructed by assigning lower values to the lower-technology categories and higher values to the higher categories. The values assigned to each category are: 1 for primary products (PP), 2 for resource-based manufacturing (RB1 and RB2), 3 for low-tech manufacturing (LT1 and LT2), 4 for medium-tech manufacturing (MT1, MT2, and MT3), and 5 for high-tech manufacturing (HT1 and HT2). The percentage of exports in each category is then multiplied by the appropriate value, and these are summed and divided by 100 . The resulting index ranges from 1 to 5 , with higher values indicating greater technological sophistication. It should be noted that the index is not a measure of the technological sophistication of the economy, but rather of the products that it exports. Although a country needs to have the technological capability to produce higher-tech products, it may or may not specialize in them for export purposes, as many other factors affect comparative advantage.

China's increased exports of more technologically advanced products is reflected in an increase in its ITS from 3.1 in 1990 to 3.7 in 2005. This is still below the 4.0 value of the index for Hong Kong, Taiwan, Japan, and Singapore in 2005 and the 3.9 for Korea. However, the indexes for these countries have generally not changed much over the past ten years, suggesting that China is rapidly catching up. For Japan, the stagnation in the ITS has occurred as its export share has shifted from the electronic high-tech category where Chinese exports have been growing rapidly (consistent with reports that Japan has shifted production facilities for high-tech products to China) into the 
medium-tech automotive category where China is a much less important competitor. However, although exports of automotive products currently comprise the smallest share of China's exports at (less than 2 percent), they also are growing rapidly, with their share of the region's exports rising from $1 \frac{1}{2}$ percent in 1995 to 7 percent in 2005. This suggests that China may become a more important competitor in this area in the future.

Korea also has seen a substantial increase in the share of its exports in the automotive category over the past ten years. This has been largely offset by a decline in the share of the low-technology categories. At the same time, the overall share of high-tech has risen, but the bigger increase has been in the HT2 category (non-electronic high-tech products), where China's share is smaller and growing less rapidly. On net, Korea's ITS has been unchanged over the period.

Taiwan's ITS rose from 3.8 to 4 over the period, along with a sharp increase in the share of its exports in the non-electronic high-tech category, where China is less dominant, from 1 to 6 percent. This may suggest an effort to find a niche separate from China. However, at the same time, the share of Taiwan's exports in the electronic high-tech category has continued to grow rapidly, and was up to almost 38 percent in 2004. Like China, Taiwan is increasingly moving out of low-tech textile manufactures. Singapore's ITS dropped slightly over the period, as the share of its exports that are electronic high-tech products fell 4 percentage points, although it remains high at nearly 50 percent. The share of engineering products also has fallen. Offsetting these declines has been an increase in the share of non-agro resource-based manufactures, which includes Singapore's rapidlygrowing biomedical sector. Singapore's share of regional exports of these products is now slightly larger than China's.

The Philippines' ITS is actually the highest for the region at 4.3, having risen significantly over the ten-year period. This has occurred as the percentage of the Philippines exports of primary products, resource-based manufactures and low-tech products have all plummeted, while electronic high-tech exports have soared. This may suggest an ability to compete with China, although it may also suggest greater vertical specialization, a point to which we return later. The indexes for the other countries are generally lower. Malaysia's ITS was 3.7 in 2005, nearly the same as in 1995, as an increase in the share of primary product exports, which includes oil, partly offset the effect of an increase in the share of electronic high-tech products. Thailand's ITS has risen slightly, from 3.2 in 1995 to 3.4 in 2005, mainly reflecting a move from primary into medium-tech products, including an increase in the share of automotive product exports. Thailand's share of electronic high-tech 
products has risen a little, but it remains relatively low for the region at about 25 percent.

Goods exports of Indonesia and India are less technologically sophisticated than in the rest of the region; India's ITS was 2.7 in 2005, little changed from 1995, with its largest percentage of exports in non-agro resource-based manufacturing. Indonesia's ITS was 2.3, with its largest export share in primary products. The share of low-tech textile manufactures has fallen, possibly reflecting increased competition from China.

In sum, the response of other countries in the region to China's increasingly dominant presence, particularly in electronic high-tech, has varied. Japan, Korea, and Thailand appear to have increasingly shifted toward production of automotive products, while Singapore has increased its presence in the non-agro resource-based manufactures market. (See Box 4 for a more detailed discussion of the region's auto industry.) Both of these are areas where China is less dominant. Conversely, the Philippines has become increasingly specialized in the electronic high-tech category which currently comprises the largest share of China's exports. Taiwan and Malaysia also have increased the share of their exports in the high-tech categories, although Malaysia also exports natural resources. Exports of Indonesia and India have remained at the lower end of the tech scale, although they still face plenty of competition from China in those categories.

\subsection{Revealed Comparative Advantage}

As another way of quantifying the changes in export structure that have taken place in the region over the past decade, we computed indices of revealed comparative advantage (RCA) in production of goods at the 5-digit SITC level for each country. RCA is measured as a product's share in the country's total exports relative to the product's share of total world exports. This comparison is based on the idea that countries reveal their comparative advantages by capturing a greater share of the world market in a product. A value less than unity indicates revealed comparative disadvantage and a value greater than unity indicates a revealed comparative advantage. The results for the 5-digit codes were aggregated by technological category and are shown in Charts 17 and 18.

Not surprisingly, for the region on average, RCA is highest in electronic high-tech manufacturing and low-tech textiles, reflecting China's strengths along with its size. There are some strong similarities among countries in the region, but also some important differences. Nine of the eleven countries had RCAs above one for HT1 in 2005 and seven had RCAs above one for LT1. Five, 
including China, had RCAs above one for both categories. The region's RCA in HT1 rose from 1995 to 2005, while its RCA in LT1 fell slightly over this period, consistent with the increase in technological sophistication noted above.

Although the increase in China's RCA in HT1 over the past ten years raised it above one, which was not the case in 1995, its highest RCA (2.3) is still in LT1, although it fell considerably over the same period. Apart from these two categories, its only other RCA above 1 is in other low-tech manufacturing, and that also fell over the ten-year period.

Both Hong Kong and Taiwan show quite a bit of similarity with China. Their areas of comparative advantage are the same and the relative sizes are similar for Hong Kong (this may reflect the fact that Hong Kong re-exports a large quantity of its imports from China). Taiwan's comparative advantage in electronic high-tech is still considerably higher than China's, although it is not rising as fast. Taiwan also has lost comparative advantage in low-tech manufacturing, although it has gained in medium-tech exports of chemicals and basic products, an area where China does not have comparative advantage.

Japan has lost comparative advantage in electronic high-tech, while increasing its comparative advantage in the medium-tech automotive category (MT1). Korea also has increased its comparative advantage in automotive and shown a smaller increase in electronic high-tech, but lost comparative advantage in the low-tech categories. Singapore and Malaysia also have high RCAs in electronic high-tech, but their other areas of specialization are non-agricultural resource-based manufacturing (Singapore) and primary products and agricultural resource-based manufacturing (Malaysia).The Philippines has shown an enormous increase in its comparative advantage in electronic high-tech, where it now has the highest RCA in the region.

Thailand's areas of comparative advantage are similar to China's, although none of its RCAs are very large. Its highest RCA is in electronic high-tech and is slightly larger than China's but growing much more slowly. Thailand also has an RCA above one in textile manufacturing, but it has fallen sharply over the ten-year period. On the other hand, Thailand has gained comparative advantage in agricultural resource-based manufacturing.

Indonesia's areas of comparative advantage are primary products, resource-based manufacturing, and textiles. These have been relatively little changed over the ten-year period. India, like China, has RCAs above one in both low-tech manufacturing categories, although its RCAs in both are higher than China's. It also has a large comparative advantage in non-agricultural resource- 
based manufacturing, and little presence in the electronic high-tech market.

In sum, an examination of the patterns of revealed comparative advantage suggest that the other countries in the region have responded to China's growing importance, but that the response has been far from uniform. One of the more interesting results is that several of the more advanced economies (Japan, Korea, and Taiwan) have seen increases in their RCAs in one or more mediumtech category, where China is less dominant, while losing comparative advantage in China's high RCA categories of low-tech manufactures and high-tech electronic manufactures. Singapore has seen a similar realignment of comparative advantage away from electronic high-tech to non-agricultural resource-based manufactures. In contrast, Malaysia, the Philippines, and Thailand have all seen increases in their RCAs in the electronic high-tech category, which may be leading to more direct competition with China.

\subsection{Displacement of Exports}

The analysis of the previous subsection implies that China's increasing presence in global markets may have contributed to a realignment of export shares for other countries in the region. In this subsection, we more formally quantify the degree of displacement by country and by product category that has occurred in response to competition from China. We might note that displacement is not necessarily a negative result, as the other countries may have optimally responded either by shifting production resources toward sectors in which they can compete or by improving the quality of the goods they produce. For the global economy, such shifts in should be a net positive, as long as they occur in accordance with the principle of comparative advantage .

We measure degree of competition from China in terms of changes in its export share as follows:

$$
V_{p t}=\frac{X_{c h i n a, p t}}{\sum_{c \in \text { world }} X_{c p t}}
$$

$X_{\text {china,pt }}$ is the value of export of product $p$ by China, $X_{c p t}$ is the value of exports of product $p$ by country $c$. Thus $V_{p t}$ measures the world share of China's export of product $p$ at time $t$ as a proxy for competition from China. In order to estimate the extent to which competition from China displaces exports of other countries in the region, we run the following Ordinary Least Squares (OLS) regression for each country in the region and by each technological category defined earlier: 


$$
\frac{X_{p t+1}-X_{p t}}{X_{p t}}=\alpha_{0}+\sum \alpha_{1 t} \text { year }_{t}+\alpha_{2} \ln \left(X_{p t-1}\right)+\alpha_{3} V_{p t-1}+\epsilon_{p t}
$$

The dependent variable is the growth of each country's total exports for product $p$ at the 5digit SITC level. ${ }^{9}$ We include yearly dummy variables to control for time effects. The parameter $\alpha_{3}$ captures the displacement effect arising from competition from China. To the extent that competition from China is crowding a country out of a product market, the coefficient will be negative and statistically significant.

Tables 7 presents the results. The technological categories examined are: HT1, HT2, MT1, MT2, MT3, LT1 and LT2, as previously defined. An analysis of $V_{p t}$ indicates that China's share has increased across all product categories between 1990 and 2005. When all the sectors are pooled, the estimated coefficient $\left(\alpha_{3}\right)$ is negative and statistically significant for 7 of the 9 countries, indicating that higher competition from China has resulted in lower export growth for these countries. For example, for Japan, a 1 percentage point increase in China's share has reduced Japan's export growth in these sectors by 0.16 percent.

The results vary by product category. Competition from China has generally had little or no effect on export growth of other Asian countries in the HT1 and HT2 categories, consistent with the previous finding that China still has a relatively low RCA in these sectors. In the automotive category (MT1), where China's share rose to 7 percent of total world exports in 2005 from 1 percent in 1995, the regression results suggest that there has been some crowding-out of exports of Japan and South Korea, two important auto producers. For the MT2 and MT3 categories where China's share has roughly tripled between 1990 and 2005, exports have generally shifted away from several countries in the region. The effect is most pronounced for Korea and India.

In the LT1 category where China's revealed comparative advantage is highest, although declining, exports of other countries have generally not experienced noticeable displacements. Quite to the contrary, China appears to have exerted a positive effect on Indonesia and the Philippines. For the LT2 category where competition from China has risen noticeably, export growth for most countries has registered significant displacements. The results are qualitatively similar to those of Ahearne et al (2006), who focused on Asian exports by industry to just the United States. They concluded that an increase in Chinese exports to the United States has crowded out exports to the

\footnotetext{
${ }^{9}$ Export values that are 0 are replaced by 0.001 .
} 
U.S. from other parts of the region in the case of some countries but not others. ${ }^{10}$

In sum, on aggregate, competition from China has risen and this has led to some displacement of exports from other countries in the region. The high-tech sector (HT1 and HT2) seem to have been largely unaffected thus far, although this could change as China increases its presence in this category. The displacement has been more pronounced in the mid-tech categories (MT1, MT2, and MT3), and and has been less noticeable in the low-tech sectors (LT1 and LT2) where China's share was already high in 1990. These findings are consistent with the hypothesis that China has conquered low-tech industries, notably textiles, garments, and footwear, and is currently crowding out other countries in the mid-tech industries on its way up the value-chain. Of course, some countries may have upgraded the quality of their exports in response to competition from China, a subject for future research. (To some extent, the crowding-out of exports may reflect productionshifting from some of the more advanced economies to China, which might also be expected to have an impact on domestic investment. Box 5 looks at this issue.)

\section{Conclusion}

Although many comparisons have been drawn between the rise of China as a global economic power and the earlier emergence of such Asian powerhouses as Japan and Korea, there are some fundamental differences between China and the others. Most importantly, China is huge. With a population of over a billion (one-fifth of the world total), many of whom are not yet in the urban labor force, China has the potential to affect markets both as a producer and consumer that few other countries have ever had. In addition, despite the increasing use of market-based transactions in China, resource allocation is still to a large extent influenced by government policy that looks favorably on export-led growth. As a result, it is easy to see why countries in the same region of the world might view China as a competitive threat in external markets. However, at the same time, China clearly offers enormous opportunities to its neighbors as both a customer and as a partner in production. China also offers the chance for all of these countries to exploit the principle of comparative advantage to achieve gains from trade, thus increasing income and contributing to improved standards of living across the region. And, as a country becomes more prosperous, domestic demand should also become an increasingly important source of economic growth, as more

\footnotetext{
${ }^{10}$ Restricting the products to finished goods only does not materially affect the results.
} 
of the population moves into the middle class.

In this paper, we have examined the reaction of the other countries in the region to the rise of China from both a macro and a micro perspective. Our most important conclusions are:

(1) External demand remains an important source of economic growth for the region, although in recent years it appears to have been more important for the more advanced economies in the region than for the less-developed. Nevertheless, economic growth has been robust across the region.

(2) There is some macro evidence that China has become a more independent source of demandan engine of growth-in recent years. However, the micro data suggest that China is still more of a conduit, importing parts and components from other countries in the region and assembling them into final goods. Moreover, this production fragmentation appears to be more important for the more-advanced than for the less-advanced countries.

(3) As China has moved up the value chain in recent years, increasing its presence in electronic high-tech exports in particular, there have also been shifts in the pattern of production in the other economies in the region. For instance, Japan and Korea have further increased their presence in the medium-tech automotive industry and Singapore has developed its biomedical sector. At the same time, the Philippines has increased its revealed comparative advantage in exports of electronic high-tech products, a large proportion of which are parts and components. However, our analysis of product displacement suggests that Chinas' increasing export share has not reduced export growth for the other countries in the high-tech industries, although it has had a negative effect in the medium-tech and low-tech industries.

Some of the implications we draw from these results are: First, although China's rise as an economic powerhouse is undisputed, at this point it is unlikely that emerging Asia could weather a significant slowdown in the U.S. economy, for example, without being noticeably affected. Second, our results on displacement of exports and changes in product mix of exports suggest that for some countries the rising trade in parts and components may be an endogenous response to competition from China, as these countries try to find areas of complementarity with China rather than compete head-to-head. Third, China's impact on the economies of the region is not uniform.

Finally it should be emphasized that the debate on these issues is still evolving (the present paper included) and is difficult to settle. Additional research is needed. In particular, acquiring a more detailed understanding of the country-specific responses to the rapid emergence of China 
would be a fruitful line of further inquiry. 


\section{References}

[1] Ahearne, Alan G., John G. Fernald, Prakash Loungani, and John W. Schindler (2006). "Flying Geese or Sitting Ducks: China's Impact on the Trading Fortunes of Other Asian Countries," International Finance Discussion Paper Number 886, Board of Governors of the Federal Reserve System, Washington, DC.

[2] Ando, Mitsuyo (2005). "Fragmentation and Vertical Intra-Industry Trade in East Asia," manuscript, Keio University.

[3] Athukorala, Prema-Chandra (2003). "Product Fragmentation and Trade Patterns in East Asia," Australian National University Working Paper No. 2003/21, October.

[4] and Trade Integration: East Asia in a Global Context," North American Journal of Economics and Finance (forthcoming).

[5] Dean, Judith, K.C. Fung and Zhi Wang (2007). "Measuring Vertical Specialization in Chinese Trade," U.S. International Trade Commission, Office of Economics Working Paper No. 200701-A, January.

[6] oyle, Brian M. and Jon Faust (2005). "Breaks in the Variability and Co-Movements of G-7 Economic Growth," Review of Economics and Statistics, November, 87(4), pp.721-740.

[7] Grubel, Herbert G. and Peter J. Lloyd (1975). Intra-Industry Trade: The Theory and Measurement of International Trade in Differentiated Products, New York: Wiley.

[8] Hummels, David \& Ishii, Jun \& Yi, Kei-Mu (2001). "The nature and growth of vertical specialization in world trade," Journal of International Economics, Volume 54, Issue 1, June, pp. 75-96.

[9] International Monetary Fund (2006). "Country and Regional Perspectives," Chapter 2, World Economic Outlook, Washington, DC, September.

[10] Kose, M. Ayhan, Eswar S. Prasad, and Marco E. Terrones (2003). "How Does Globalization Affect the Synchronization of Business Cycles?" American Economic Association, Papers and Proceedings, May.

[11] Lall, S. (2000) "The technological structure and performance of developing country manufactured exports, 1985-98", Oxford Development Studies, Vol. 28, No. 3, 337-69.

[12] Lee, Chung H. and Michael G. Plummer (2004). "Economic Development in China and Its Implications for East Asia," University of Hawaii-Manoa and Johns Hopkins University School of Advanced International Studies-Bologna, Working Paper No. 04-11.

[13] Schott, Peter K., (2002), "Moving Up and Moving Out: US Product Level Exports and Competition from Low Wage Countries," Yale School of Management, mimeo. 


\section{Box 1: Regional Growth in Service Exports}

One additional response of Asian economies to competition from China in the manufacturing sector has been to move toward greater export of services. Although still under 15 percent of total regional exports, service exports from Asia have risen at a sharp $181 / 2$ percent annual rate between 2001 and 2006. Over this period, as a share of total exports, services have fallen a touch for China, but have held steady or edged up, on average, for the rest of the region, suggesting some increasing relative specialization in services outside of China Services Share of Exports

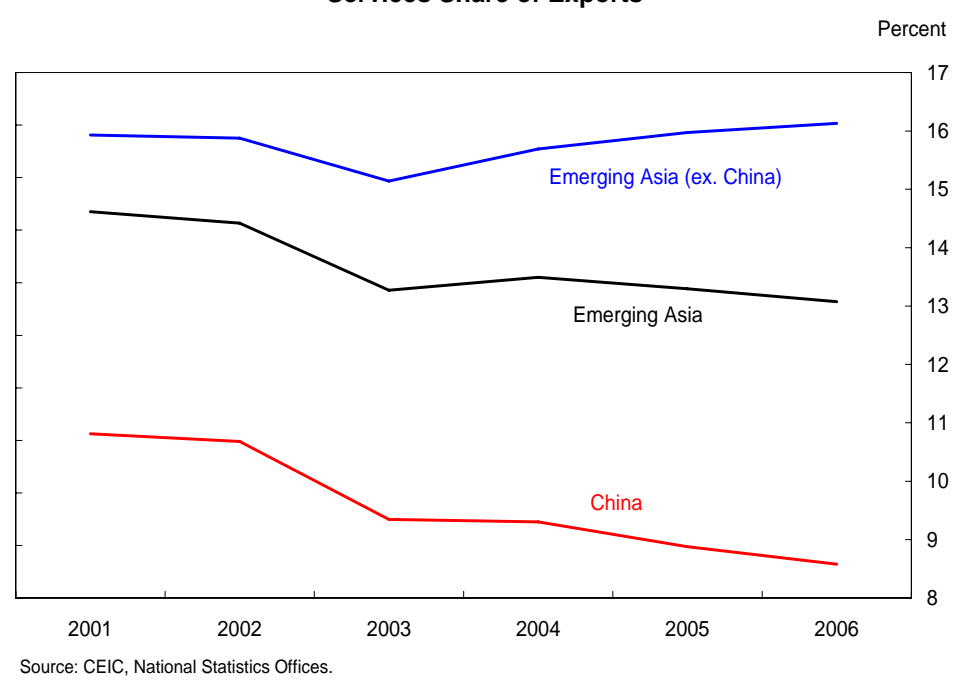
(chart).

The success of India's outsourcing sector provides a key example of specializing in services. Between 2001 and 2006, India’s service exports rose at a 341/2 percent annual rate - almost double the average pace of the region. Moreover, the share of services in India's total exports rose to almost 40 percent in 2006, compared with 13 percent for the region as a whole. The Philippines is another oft-cited example of a country with a rising emphasis on outsourcing and service exports. Exports of business services and computer and information services have risen at an over 30 percent annual pace in the past 5 years and now account for nearly 20 percent of the country’s service exports. Surprisingly, the share of services in the Philippines total exports has actually fallen slightly to 16 percent since 2001, reflecting the country’s even faster pace of manufacturing export growth. 
Although there is some evidence that certain Asian countries are increasingly specializing in service exports, China's service sector is expanding as well. In terms of GDP growth in the service sector, China matches India's pace recently and service exports for China have been growing at 22 percent annual rate since 2001, above the regional average. China has also been a strong competitor in the computer and information services industries, where export growth has risen almost 45 percent annually since 2001, though exports are still roughly 15 percent of the level of India software services exports. The fast pace of China's manufacturing export growth over the past 5 years has led to a shrinking share of services in overall Chinese exports. For the region, however, China's share of services exports has risen sharply (chart). Overall, these figures suggest that service exports from Asia are growing and represent another avenue of growth for the region - both for China and for the other countries.

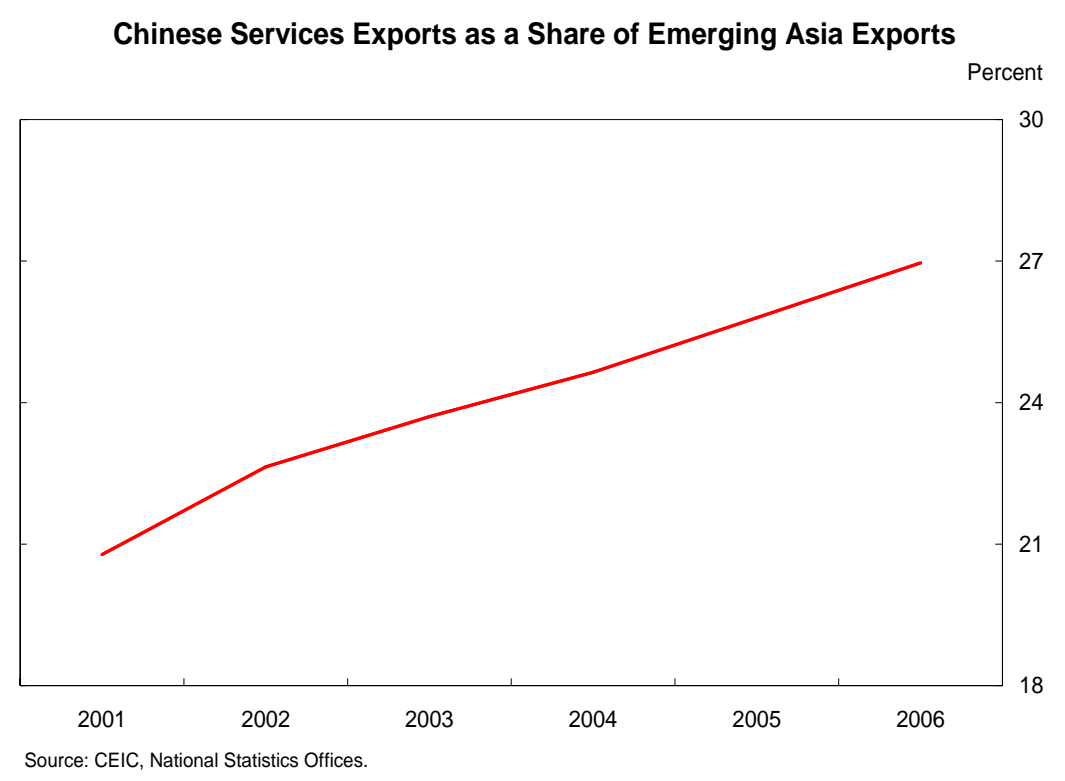




\section{Box 2: The Tourism Strategy}

China's recent explosive growth has created a sizable middle class with cash to spend and hungry for goods they cannot obtain in the mainland. This transformation has changed the very face of the global tourism industry. Chinese tourists are now being welcomed (and indeed actively attracted) to far-away destinations never imagined possible previously. ${ }^{1}$

One country that took early advantage of the market for Chinese tourism is Hong Kong. In 2004, China and Hong Kong signed the Closer Economic Partnership Agreement, which among other things allowed a greater number of Chinese tourists to visit Hong Kong. The results have been stunning. The following year, visitor arrivals to Hong Kong from China were nearly twice the resident population of Hong Kong, accounting for over half of all visitors arriving.

However, this phenomenon is not unique to Hong Kong. The share of Chinese visitors arriving in almost every Asian country has steadily risen since at least 1995. The exceptions are the

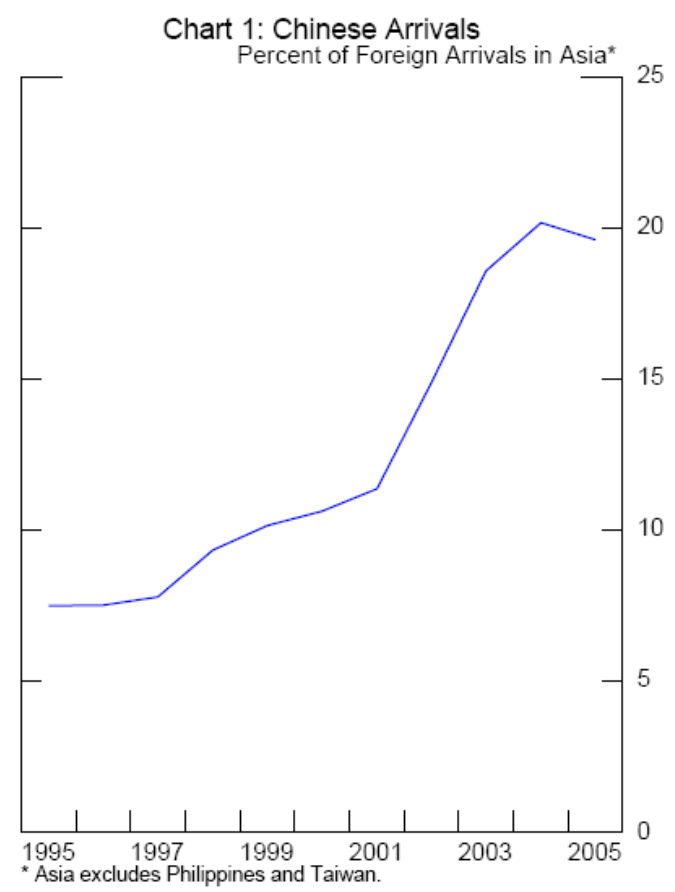
relatively less-expensive destinations of Malaysia and Thailand. The share of Chinese visitors to all other Asian countries rose from about 7 percent in 1995 to about 20 percent in $2005 .^{2}$

However, China still maintains a positive net visitor arrival with almost every country in the region. For example, in 2005, China registered 3 million more visitor arrivals from Japan than Japan registered from China. ${ }^{3}$

\footnotetext{
${ }^{1}$ See "Germany's campaign to attract Chinese tourists", "Japan, a Net Exporter of Tourists, Working Hard to Attract Chinese Tourist", "Arabic nations attract Chinese tourists," "Drive to attract Chinese golfers," "Hawaii to attract Chinese tourists."

${ }^{2}$ Data for the Philippines is not available before 2001, but data since then confirm the rising trend of Chinese visitors. Taiwan does not report the number of tourist arrivals from China, partly reflecting the political tensions between the two countries.
} 


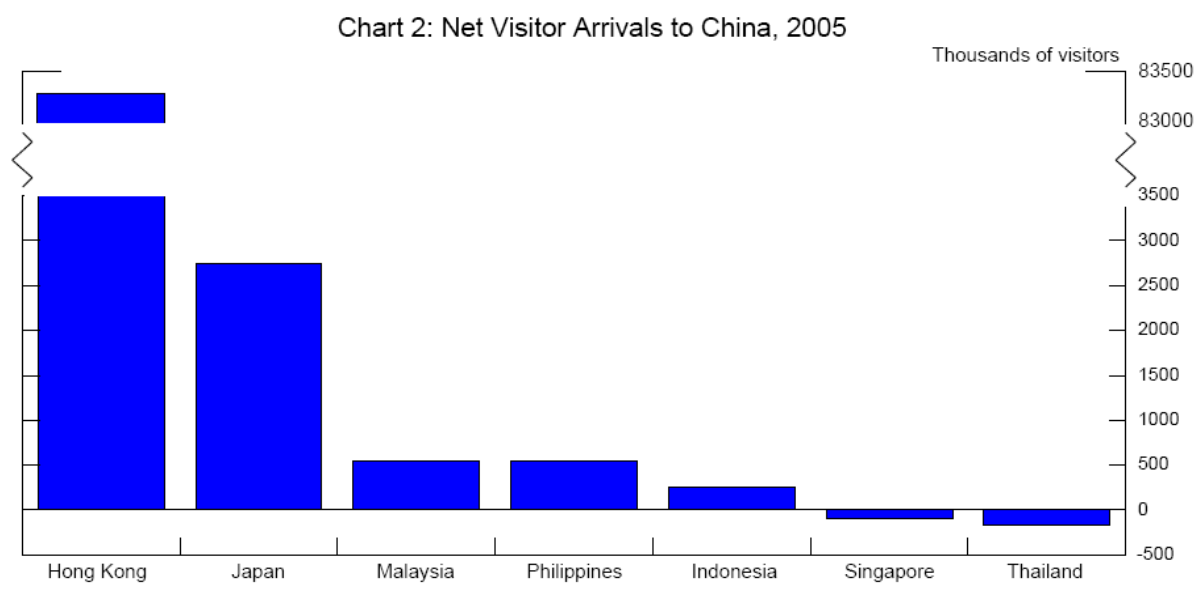

Data on the departure destinations of residents in each country (not shown) are sketchy. But, they confirm that among countries in the region, Hong Kong is the favorite destination of Chinese travelers: over 40 percent visited Hong Kong in 2005. They also confirm an increase in the extent of intra-regional tourism trade. In other words, a greater proportion of residents from the region are visiting other countries in the region. For some countries, such as Hong Kong, Korea, and Thailand, visits to China are largely responsible for this increase.

Whether it is as a destination or an origination country, the economic opening in China is changing Asian tourism in important ways.

\section{References}

“Germany's campaign to attract Chinese tourists," Expatica.com, August 2004. http://www.expatica.com/actual/article.asp?subchannel_id=214\&story id=10373

"Japan, a Net Exporter of Tourists, Working Hard to Attract Chinese Tourist," The Yomiuri Shimbun, Aug. 6, 2005. http://www.hotel-online.com/News/PR2005 3rd/Aug05 JapanChina.html

“Arabic nations attract Chinese tourists," People's Daily Online, January 1, 2006. http://english.people.com.cn/200601/01/eng20060101 232179.html

"Drive to attract Chinese golfers," The Scotsman, March 21, 2006. http://thescotsman.scotsman.com/index.cfm?id=440342006

"Hawaii to attract Chinese tourists," Shandong Business Net, April 6, 2006. http://www.shandongbusiness.gov.cn/english/php/show.php?id=3219

\footnotetext{
${ }^{3}$ This data must be analyzed with caution for several reasons. First, it does not distinguish between travel for business versus travel for pleasure. Second, it also fails to distinguish arrivals who are in transit to another country.
} 


\section{Box 3: The Philippines Electronics Sector}

Exports of high-tech products make up nearly 70 percent of the Philippines' total exports, the highest in emerging Asia. However, high-tech goods have not always been the dominant export product category. In what follows, we review the development of the high-tech sector in the Philippines and the unique role played by the globalization and fragmentation of the hightech supply chain.

In the early 1990 s, the share of electronics in Philippine's total exports was not as high. It rose considerably from 24 percent of exports in 1994 to 50 percent in 1996, and has hovered at nearly 70 percent since $1998 .{ }^{1}$ During

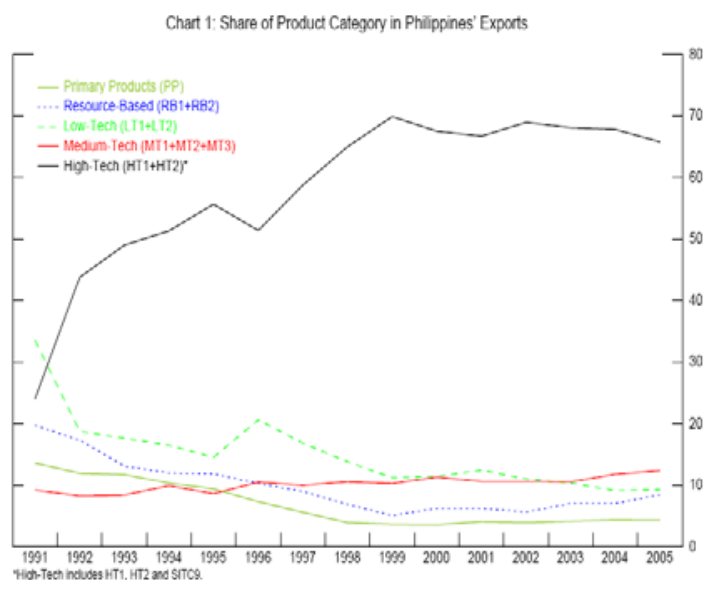
that period, exports of low technology products (LT), resource based products (RB) and primary products (PP) declined.

As the share of electronics in total exports rose, the share of imports of electronics rose in tandem. In 1991, the imports of high-tech products (the HT category) accounted for 22 percent of total imports. Its share had risen to 35 percent by 1996, and to over 45 percent since 1998.

The explanation for these features of the Philippine electronic sector is rooted in the

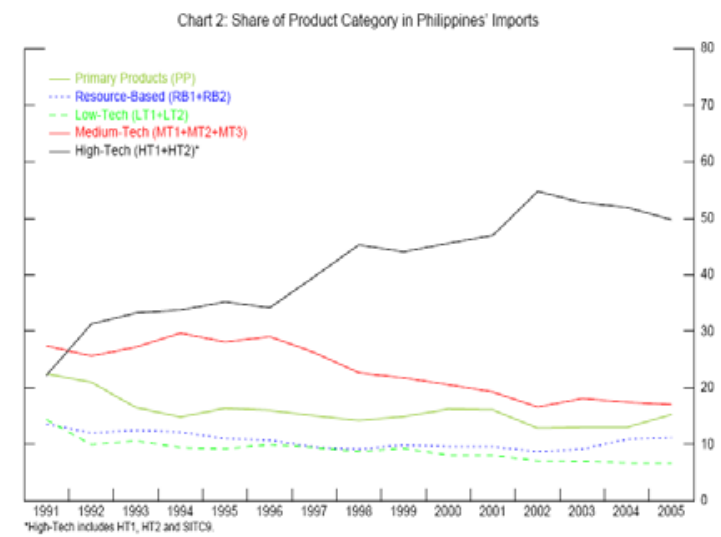
history of the development of the global electronics industry, mainly by U.S. and Japanese firms. In the mid-1980s, U.S. firms had expanded production to emerging Asia in order to reduce production costs through relatively cheap labor. They expanded first to Singapore, and later to Thailand and Malaysia. The rapid development of the Philippines electronic sector was the result of policies by Japanese firms in order to remain competitive vis-à-vis U.S. firms in the global production of electronics. For example, Sunward Technology, a U.S. firm, began operations in the Philippines in March 1988. In May of the same year, Sunward Technology was followed by

\footnotetext{
${ }^{1}$ Electronics consists primarily of the HT1 and HT2 categories. With exercise of some judgment, we also include a category labeled "other".
} 
Tsukiden Electronics Industries, a subsidiary of the Japanese Tsukiden group. The momentum was interrupted by political instability in the Philippines, including a December 1989 military coup, and by a well-publicized kidnapping of a Japanese executive and a recession that lasted until 1993 (Tecson 1999).

The return of political stability and an improved economic environment after 1993 marked the beginning of a new wave of investment in the electronics sector. In 1994, Hitachi, Fujitsu and Toshiba began expanding production capacity in the Philippines. The entry of these Japanese multinationals was accompanied by the relocation of Japanese supplier firms between 1994 and 1996, including Nidec Philippines Corporation (1995), Luzon Electronics Technology, Tsukuba Philippine, San Technology, Mette, Precision Technology etc.

\section{Why the Philippines?}

Japanese and U.S. firms expanded production to Asia to reduce production costs. The high concentration of investment by Japanese firms in the Philippines in particular was motivated by the following reasons:

First, the Philippines' geographical location offers several advantages. It provides easy access to different countries of East and Southeast Asia which serve as sources of parts and components of electronics products. It is closer to Japan than Singapore, Malaysia, and Thailand, which allows a better and faster interaction between headquarters and the subsidiaries in the Philippines. This close proximity between the Research and Development centers in Japan and subsidiaries and suppliers in the Philippines helped reduce the product cycle. Second, the Philippines has a relatively abundant supply of engineers, and graduates from technical schools. The relatively high supply lowered labor costs for skilled workers compared to other countries in the region. For example, as of 1997, the wages of a graduate from a technical school in Indonesia were 1.4 times higher than that of a Philippine graduate. The corresponding factor was 2.5 for Thailand, 3.1 for Malaysia, and 6.9 for Singapore (see Table below). Third, many Philippine workers are fluent in English. This facilitated communication between Japanese and U.S. managers and their subsidiaries or contractors in the Philippines. It also reduced the cost of training workers. It was estimated that a Japanese firm would have to provide at least 90 hours of language training in Thai to its Japanese engineers and managers assigned to Thailand in order for them to have the minimum communication capabilities. 
Relative Wages Levels in ASEAN-5

\begin{tabular}{lccc}
\hline Country & $\begin{array}{c}\text { Factory } \\
\text { Workers }\end{array}$ & $\begin{array}{c}\text { Junior High School } \\
\text { Graduates }\end{array}$ & $\begin{array}{c}\text { Technical College } \\
\text { Graduates }\end{array}$ \\
\hline Philippines & 1.0 & 1.0 & 1.0 \\
Indonesia & 0.63 & 0.54 & 1.36 \\
Thailand & 1.23 & 1.29 & 2.46 \\
Malaysia & 1.28 & 1.36 & 3.12 \\
Singapore & 4.10 & 4.70 & 6.91 \\
\hline
\end{tabular}

Source: Tecson (1999) Information Storage Industry Center.

The outsourcing of production to the Philippines accounts for the rapid development of the high-tech sector in the country's exports. In the fragmentation of the production process, parts and components are shipped from the headquarters of multinational firms located mostly in Japan or the United States, where the products are designed, to the Philippines. Plants in the Philippines assemble, test, and export the final product to markets in the United States, Japan and elsewhere. This feature of the production process accounts for the high share of electronics in Philippines trade, notably with Chart 3: U.S. and Japan Combined Share of High-Tech* Trade

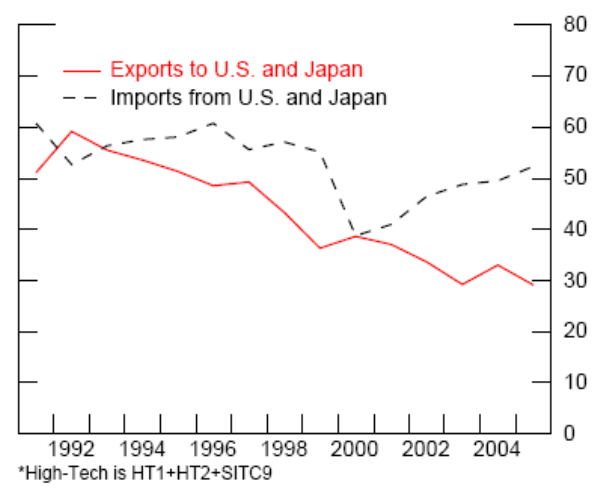
the United States and Japan- its main trading partners. It is no surprise that about 50 percent of the Philippines imports of high-tech (HT) products originated in Japan and the US, and about 50 percent of HT exports were destined to the US and Japan, at least until 1997. Since 1997, the share of exports to the US and Japan has been declining steadily. This decline is mostly due to a fall in the share of exports to the US as the share of exports to Japan held steady (see Chart 3).

On the other hand, the share of the Philippine's high-tech trade with China, though small, Chart 4: China's Share of High-Tech* Trade

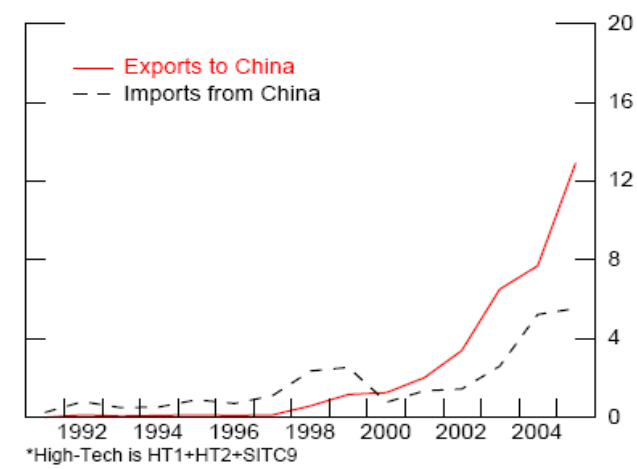
has been increasing rapidly, especially on the export side. The share of Philippines' HT exports going to China has risen from 1.3 percent in 2000 to 13 percent in 2005, and the share of exports has surpassed the share of imports. 
The relatively high share of high-tech products in exports of the Philippines is partially offset by high imports. Electronics exports have made up about 30 percent of GDP since 1998, while imports have averaged 25 percent. In 2005 exports of HT stood at 27.5 percent of GDP and imports at 25.0 percent, resulting in a trade balance of 2.5 percent of GDP for electronics. However, the trade balance in electronics does not capture all of the benefits of the electronic sector for the economy. These include employment creation and consequent domestic expenditures, technology spillovers, creation of domestic firms that are sub contractors or Chart 5: High-Tech* Trade as a Percent of GDP

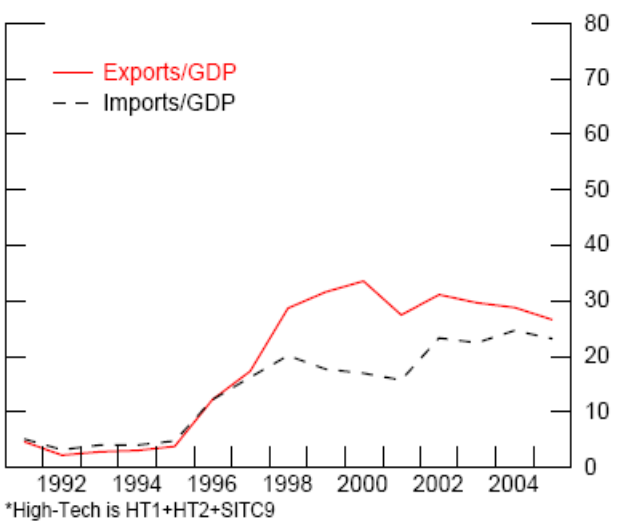
direct beneficiaries of the presence location of the multinationals in the country.

\section{References:}

Tecson, Gwendolyn R. (1999) “The Hard Disk Drive Industry in the Philippines” Information Storage Industry Center, Report 99-01, University of California, San Diego. 


\section{Box 4: The Big 3 Asian Automotive Exporters}

Japan continues to be the top exporter of automotive products in Asia. ${ }^{1}$ For over 10 years, about a quarter of Japanese exports of goods have been in automotive products. ${ }^{2}$ However, as a share of global automotive exports, Japan's share has actually fallen from 19 percent in 1995 to 12 percent in 2005. This decline has occurred in both finished automotive products and automotive parts and components. These developments have in part reflected a shift of Japanese firms' production capacity toward foreign consumer markets abroad, replacing some Japanese exports with domestic production within the destination market country. Also known as horizontal FDI, this strategy poses numerous advantages for Japanese firms over the previous produceat-home process. Initially, the strategy allowed Japanese firms to avoid U.S. quotas on finished motor vehicles. Today, some of the benefits include lower shipping costs, faster time to market, and better customer feedback. The data also support this hypothesis in other ways. For instance, since 1990, an increasing proportion of Japan's

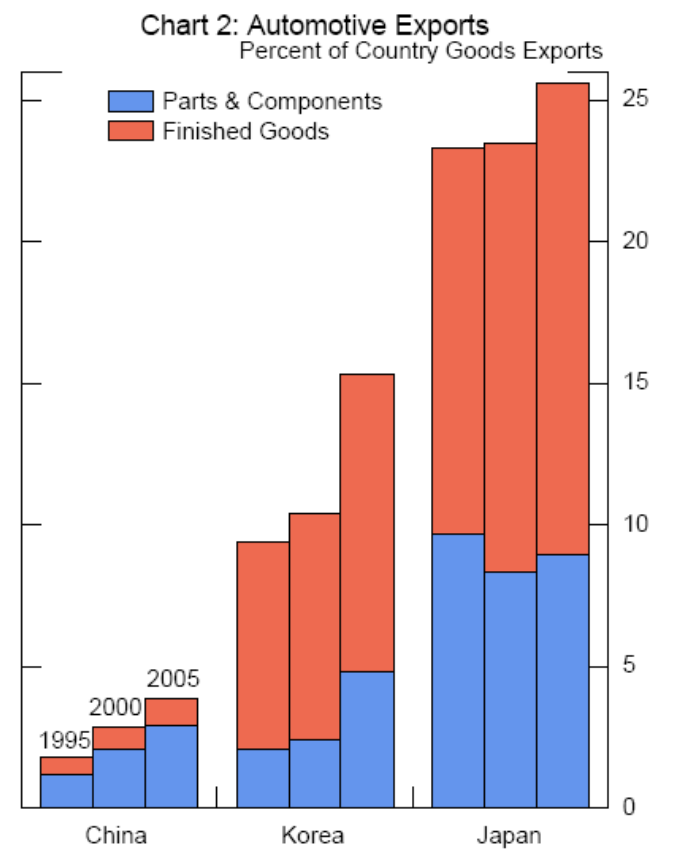
automotive exports are parts and components, presumably to be used in the assembly of finished automotive products in Japanese factories abroad.

\footnotetext{
${ }^{1}$ Indeed, Toyota Corporation is now well on its way to becoming the largest automaker in the world. In the first quarter of 2007, Toyota surpassed General Motors in worldwide vehicle sales. See "Toyota ends GM's reign as leader in global sales," International Herald Tribune, April 24, 2007.

${ }^{2}$ In this box, we do not use the technological definition of automotive products (MT1) described earlier in the paper, because this definition excludes important automotive parts and components.
} 
However, the fact that other countries (including some in Asia) have made important inroads in the automotive industry may also partly explain the reduction in Japan's share of global automotive exports. One such country is Korea, whose automotive exports have risen significantly over the past decade. In the late 1990s, Korean automakers, such as Kia Motors, went global, supplying their cars to a broad set of countries. Today, Korean motor vehicles are considered similar in quality to Japanese automobiles in some cases. As a result, it is no surprise that the share of Korean exports accounted for by automotive products has been on the rise, reaching 15 percent in 2005 . Unlike Japan, Korea's share of global automotive exports has risen significantly. In the automotive parts and components sector, Korea's share of the global market more than doubled in a decade, reaching almost 2 percent in 2005. In the automotive finished goods sector, Korea's share was even larger at 6 percent in 2005.

The new kid on the block in the Asian automotive industry is of course China. In 2005, just 4 percent of Chinese goods exports were in automotive products. Nevertheless, this is still a substantial increase from about 1 percent in early the 1990s. Unlike Japan and Korea, where finished automotive products account for a large fraction of automotive exports, China has focused its incursion in the automotive industry in parts and components. Indeed, in 2005, Chinese exports of automotive parts and components accounted for almost 3 percent of the global market, substantially

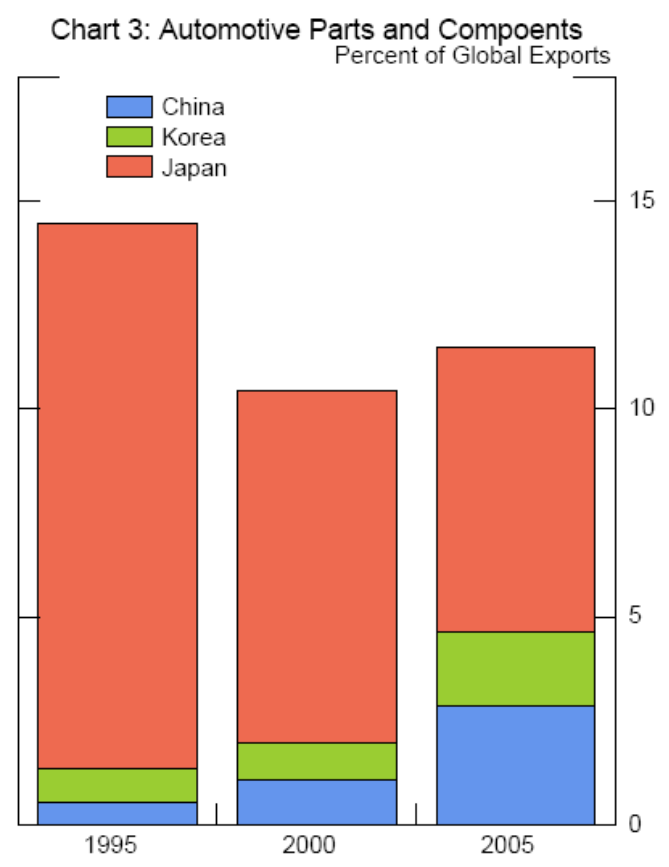
higher than Korea's share. Although China also has a large motor vehicle industry, its output is largely destined for the domestic market. One problem that Chinese exporters of finished motor vehicles face is serious skepticism about the quality of their product. Even though several Chinese automakers have stated their intention to export their cars, their ability to do so may remain limited until these quality issues are resolved. However, these issues are not insurmountable and the time may come when automotive safety governmental agencies in the industrialized countries certify Chinese cars as ready for 
their roads. For the time being, China continues to account for a miniscule portion of the global market for finished automobiles; just 1 percent in 2005.

However, the automotive industry is changing quickly in other ways. In particular, many industry analysts expect automobiles to become increasingly electronically sophisticated. Upgrades include flat panel screens showing video to improved electronic safety features. Some countries in the region are poised to take advantage of this these developments, leaving the more labor intensive automotive parts to low-cost China. For instance, Taiwan is actively trying to leverage its comparative advantage in electronics to get onto the automotive electronics bandwagon. ${ }^{3}$ For instance, the Taiwanese government has backed two groups actively engaged in auto electronics R\&D (Hua-chuang Automobile Information Technical Center and the Automotive Research and Testing Center) and subsidized numerous R\&D projects with the aim of developing niche products for Taiwanese automotive parts

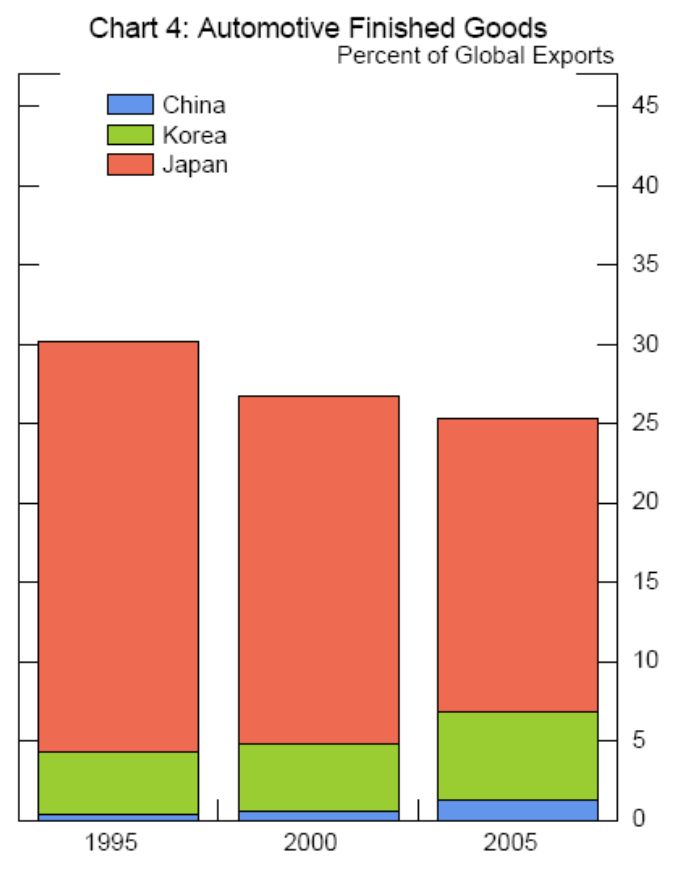
producers, including automotive multimedia entertainment systems, automotive navigation systems, tire pressure monitoring systems, automotive PCs, LED lights, solar windows, and an automotive smart chip that will use radio-frequency identification and bio-identification technology to enhance the anti-theft functions and data management systems of automobiles.

In the face of rising Chinese automotive production, the trend toward the integration of electronic technologies into the automotive sector has been a welcome development for other Asian countries that would like to keep or gain a foothold in the automotive industry.

\footnotetext{
${ }^{3}$ See "Auto PCs Spark New Business Opportunities", Taiwan Economic News 3/22/07 and "Taiwan Eyes Lucrative Auto-electronics Business," Taiwan Economic News 3/19/2007.
} 


\section{Box 5: Foreign Direct Investment by Other Asian Economies in China}

As shown in Chart 1, foreign direct investment in China from the more advanced countries in the Asian region is sizable, and rose particularly sharply in the 2003-2005 period for Japan and Korea. ${ }^{1} \quad$ This is consistent with other evidence that these countries have shifted production to China to take advantage of its lower labor costs. FDI from Hong Kong into China is considerably larger than for the other countries, and is shown on a separate scale on the right of the chart. Although this investment undoubtedly reflects some production shifting, it also includes FDI from countries outside the region that flows into China from corporate affiliates in Hong Kong.

What impact does such production-shifting have on the home economies? If corporations make investments abroad that they might otherwise have made at home, it may have the effect of depressing domestic investment, at least temporarily. As shown in Chart 2, the size of FDI into China from these countries as a portion of their domestic investment varies widely, from less than 1 percent for Japan to 8-10 percent for Singapore and 50 percent for Hong Kong (again shown on a separate scale). Since 2000, the average amount of FDI has been 49 percent of domestic investment for Hong Kong, 81/2 percent for Singapore, 5 percent for Taiwan, 2 percent for Korea, and $1 / 2$ percent for Japan. However, the percentage has generally declined in the past few years, suggesting that the current wave of production-shifting may have peaked.

Chart 3 provides mixed evidence as to whether FDI to China has crowded out domestic investment in these economies in the past few years. It appears that this may have been the case in Taiwan between 2001 and 2004 and perhaps over the last several years for Japan. The other cases are less clear.

Simple regressions of domestic investment on FDI into China suggest a similar conclusion (table 1). Domestic investment in both Taiwan and Japan show a negative correlation with FDI, while investment in Korea, Singapore, and Korea shows a positive correlation. However, when a lagged dependent variable is included the results are not significant for either Japan or Korea. The coefficients are significant for Taiwan, where it appears that a \$1 increase in Taiwanese FDI into China is associated with a $\$ 10$ reduction in domestic investment, and for Singapore, where a $\$ 1$ increase in Singaporean FDI into China is associated with a \$4 increase in domestic

\footnotetext{
${ }^{1}$ Data are from China's national statistics. FDI attributed to Hong Kong is even, but includes a substantial amount of FDI that originates in other countries, and so is not shown.
} 
investment. For Hong Kong, a \$1 increase in FDI into China is associated with a \$2 increase in domestic investment.

Although the results for Singapore and Hong Kong may appear to be contrary to expectations, they may reflect the fact from corporations from outside the area sometimes establish headquarters in the more advanced economies that are then used as a springboard for investment into China. In this situation, FDI into China and domestic investment are complements rather than substitutes.

\begin{tabular}{|l|c|c|c|c|}
\hline \multicolumn{5}{|c|}{ Effect of FDI on Domestic Investment } \\
\hline & FDI & $\begin{array}{c}\text { Lagged Dom. } \\
\text { Inv. }\end{array}$ & Adj. R & DW \\
\hline Taiwan & $-10.38^{*}$ & -.16 & & \\
& $(3.30)$ & $(.27)$ & .48 & 1.77 \\
\hline Japan & -24.50 & $.63^{*}$ & & \\
& $(-32.65)$ & $(.21)$ & .53 & 1.56 \\
\hline Korea & 7.32 & .64 & & 1.51 \\
\hline Singapore & $(6.46)$ & $(.31)$ & .39 & 1.96 \\
\hline Hong Kong & $\left(1.33^{*}\right.$ & $.69^{*}$ & & \\
& $(1.73)$ & $(.20)$ & .60 & 1.99 \\
\hline
\end{tabular}

Standard errors in parenthesis

${ }^{*}$ significant at the $5 \%$ level 
Chart 1: Foreign Direct Investment in China by Other Asian Economies

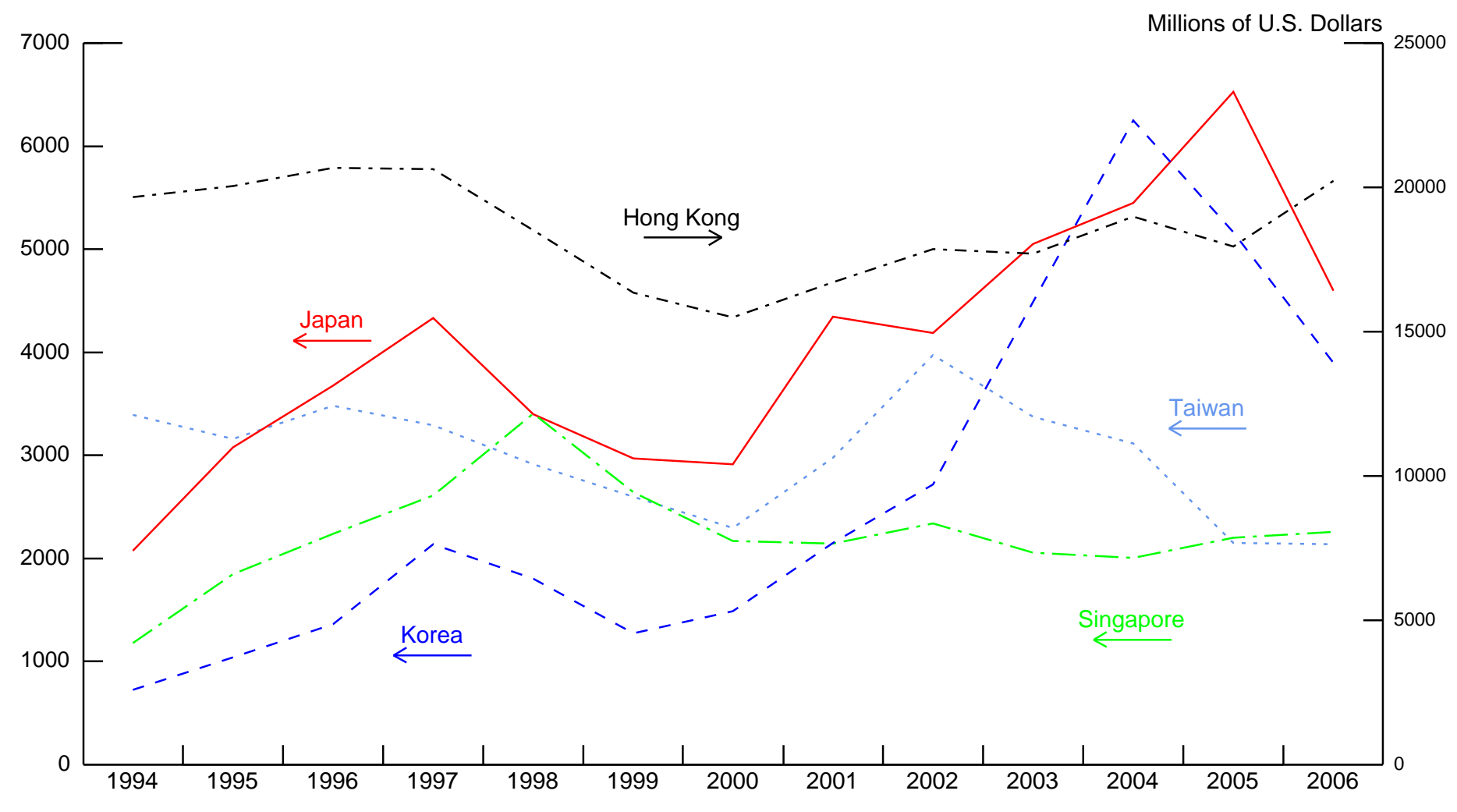

Chart 2: Foreign Direct Investment in China by Other Asian Economies

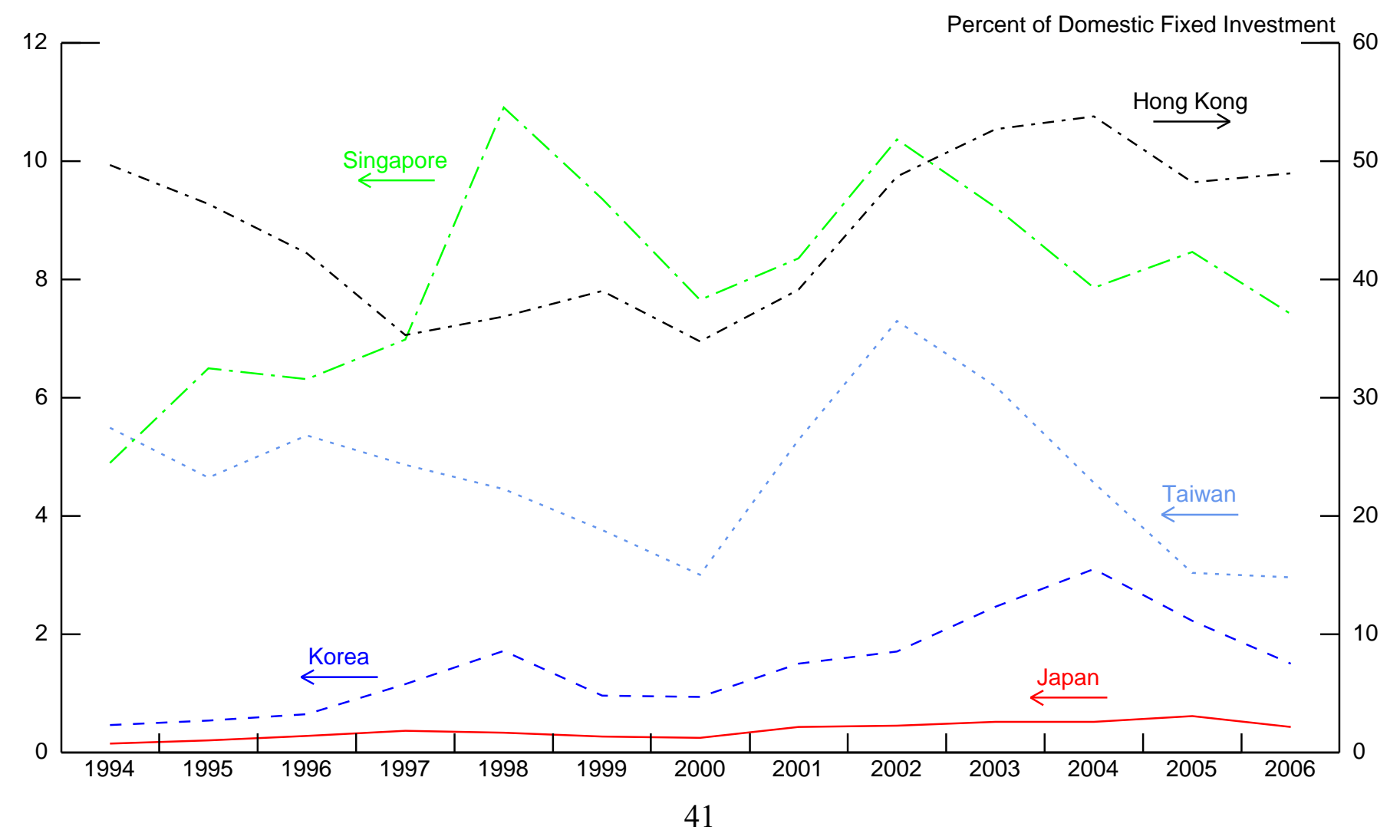




\section{Chart 3: FDI into China vs. Domestic Investment}

Taiwan

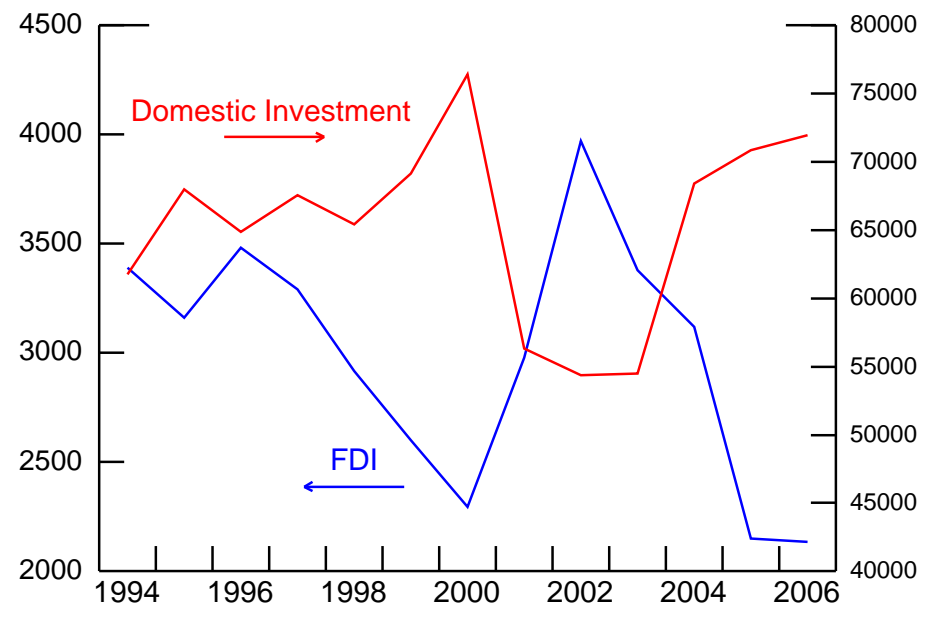

South Korea

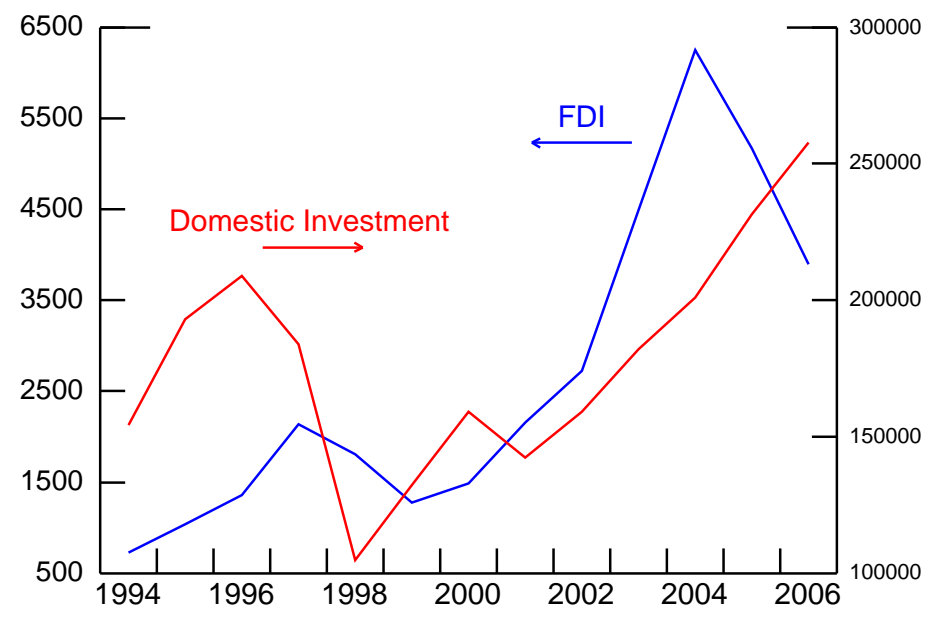

Hong Kong

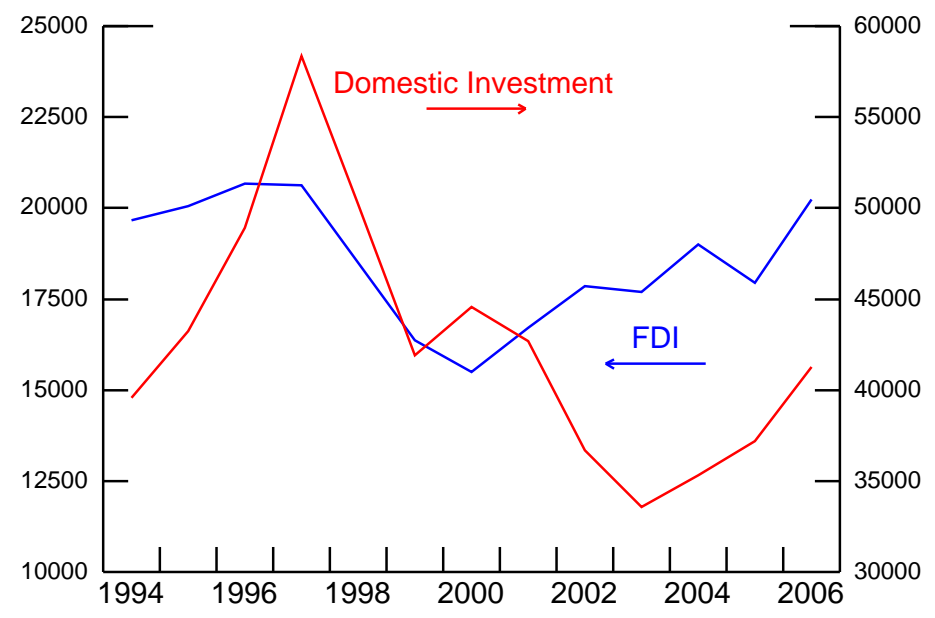

Japan

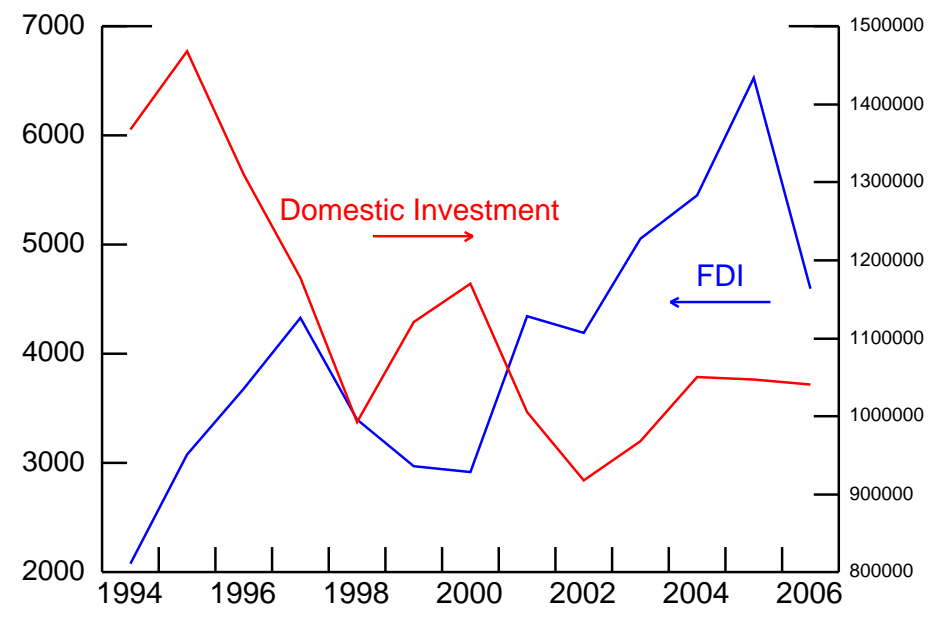

Singapore

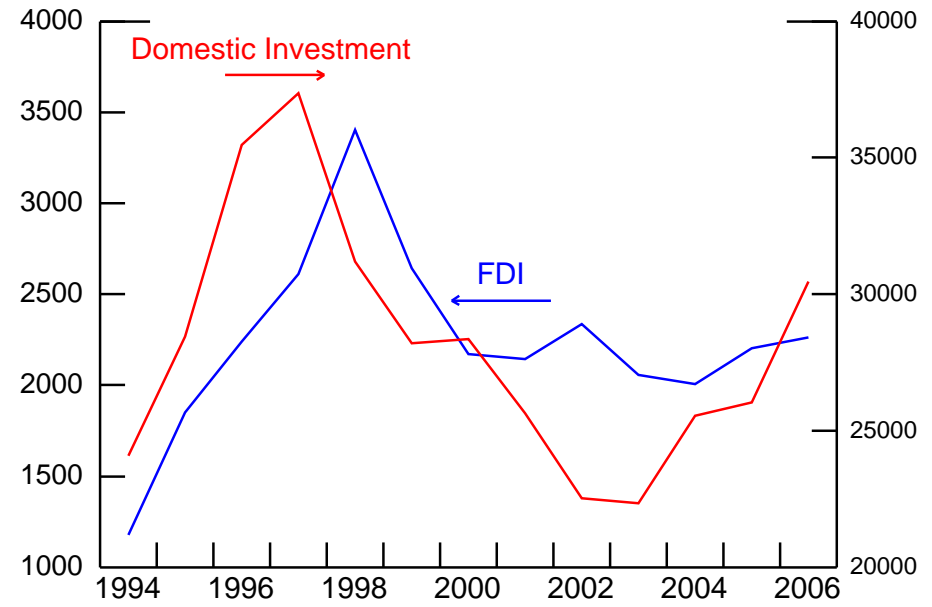


Table 1:

Variance Decompositions based on the estimated VAR

\begin{tabular}{|c|c|c|c|}
\hline \multirow{2}{*}{$\begin{array}{c}\mathrm{k} \\
\text { (quarters) }\end{array}$} & \multicolumn{3}{|c|}{$\begin{array}{l}\text { KOREA: Percent of the k-step ahead forecast error variance of } \\
\text { domestic output growth explained by: }\end{array}$} \\
\hline & $\begin{array}{l}\text { Exports to } \\
\text { U.S. Shock }\end{array}$ & $\begin{array}{l}\text { Exports to } \\
\text { China Shock }\end{array}$ & $\begin{array}{l}\text { Other } \\
\text { Shocks }\end{array}$ \\
\hline 1 & 10.8 & $17.0^{\star}$ & $72.1^{\star \star}$ \\
\hline 2 & $13.3^{*}$ & $20.6^{*}$ & $66.1^{\star \star}$ \\
\hline 3 & $25.5^{\star \star}$ & $18.3^{*}$ & $56.2^{\star \star}$ \\
\hline 4 & 26.0 ** & $24.2^{*}$ & $49.8^{\star *}$ \\
\hline \multicolumn{4}{|c|}{$\begin{array}{l}\text { NOTES: Results based on a 3-variable VAR consisting of growth of exports to U.S., } \\
\text { growth of exports to China and HK, and domestic growth; sample period 1993:2 to } \\
\text { 2006:4, and } 5 \text { lags. A '*' and "***" indicate statistical significance based on 90 percent } \\
\text { and } 95 \text { percent confidence bands, respectively, computed from Monte Carlo simulations } \\
\text { (5000 replications). }\end{array}$} \\
\hline
\end{tabular}

\begin{tabular}{|c|c|c|c|}
\hline \multirow{2}{*}{$\begin{array}{c}\mathrm{k} \\
\text { (quarters) }\end{array}$} & \multicolumn{3}{|c|}{$\begin{array}{l}\text { SINGAPORE: Percentage of the k-step ahead forecast error } \\
\text { variance of domestic output growth explained by: }\end{array}$} \\
\hline & $\begin{array}{l}\text { Exports to } \\
\text { U.S. Shock }\end{array}$ & $\begin{array}{l}\text { Exports to } \\
\text { China Shock }\end{array}$ & $\begin{array}{l}\text { Other } \\
\text { Shocks }\end{array}$ \\
\hline 1 & 2.6 & $19.2^{\star \star}$ & $78.2^{* *}$ \\
\hline 2 & $20.1^{\star \star}$ & $17.5^{\star}$ & $62.3^{\star \star}$ \\
\hline 3 & $21.3^{\star \star}$ & $20.6^{\star *}$ & $58.1^{\star *}$ \\
\hline 4 & $24.4^{\star \star}$ & $21.2^{\star *}$ & $54.4^{\star \star}$ \\
\hline \multicolumn{4}{|c|}{$\begin{array}{l}\text { NOTES: Results based on a 3-variable VAR consisting of growth of exports to U.S., } \\
\text { growth of exports to China and HK, and domestic growth; sample period 1993:2 to } \\
2006: 4 \text {, and } 7 \text { lags. A '*' and "**" indicate statistical significance based on } 90 \text { percent } \\
\text { and } 95 \text { percent confidence bands, respectively, computed from Monte Carlo simulations } \\
\text { (5000 replications). }\end{array}$} \\
\hline
\end{tabular}

\begin{tabular}{|c|c|c|c|}
\hline \multirow{2}{*}{$\begin{array}{c}\mathrm{k} \\
\text { (quarters) }\end{array}$} & \multicolumn{3}{|c|}{$\begin{array}{c}\text { TAIWAN: Percentage of the k-step ahead forecast error variance } \\
\text { of domestic output growth explained by: }\end{array}$} \\
\hline & $\begin{array}{l}\text { Exports to } \\
\text { U.S. Shock }\end{array}$ & $\begin{array}{c}\text { Exports to } \\
\text { China Shock }\end{array}$ & $\begin{array}{c}\text { Other } \\
\text { Shocks }\end{array}$ \\
\hline 1 & 6.3 & $24.3^{* *}$ & $69.4^{\star \star}$ \\
\hline 2 & 10.2 & $26.2^{\star \star}$ & $63.6^{* *}$ \\
\hline 3 & 11.1 & $29.9^{\star \star \star}$ & $59.0^{\star *}$ \\
\hline 4 & $12.3^{*}$ & $31.3^{\star *}$ & $56.4^{* *}$ \\
\hline \multicolumn{4}{|c|}{$\begin{array}{l}\text { NOTES: Results based on a 3-variable VAR consisting of growth of exports to U.S., } \\
\text { growth of exports to China and HK, and domestic growth; sample period 1993:2 to } \\
\text { 2006:4, and } 4 \text { lags. A “*' and "***" indicate statistical significance based on } 90 \text { percent } \\
\text { and } 95 \text { percent confidence bands, respectively, computed from Monte Carlo simulations } \\
\text { (5000 replications). }\end{array}$} \\
\hline
\end{tabular}


Table 1: (continued)

Variance Decompositions based on the estimated VAR

\begin{tabular}{|c|c|c|c|}
\hline \multirow{2}{*}{$\begin{array}{c}\mathrm{k} \\
\text { (quarters) }\end{array}$} & \multicolumn{3}{|c|}{$\begin{array}{l}\text { INDONESIA: Percentage of the k-step ahead forecast error } \\
\text { variance of domestic output growth explained by: }\end{array}$} \\
\hline & $\begin{array}{l}\text { Exports to } \\
\text { U.S. Shock }\end{array}$ & $\begin{array}{l}\text { Exports to } \\
\text { China Shock }\end{array}$ & $\begin{array}{l}\text { Other } \\
\text { Shocks }\end{array}$ \\
\hline 1 & 8.9 & 1.8 & $89.3^{\star *}$ \\
\hline 2 & 10.5 & 3.4 & $86.1^{\star \star}$ \\
\hline 3 & $12.9^{\star \star}$ & 5.8 & $81.3^{\star \star}$ \\
\hline 4 & $14.1^{\star \star}$ & 7.6 & $78.3^{\star *}$ \\
\hline \multicolumn{4}{|c|}{$\begin{array}{l}\text { NOTES: Results based on a 3-variable VAR consisting of growth of exports to U.S., } \\
\text { growth of exports to China and HK, and domestic growth; sample period 1993:2 to } \\
\text { 2006:4, and } 4 \text { lags. A '*' and “**” indicate statistical significance based on } 90 \text { percent } \\
\text { and } 95 \text { percent confidence bands, respectively, computed from Monte Carlo simulations } \\
\text { (5000 replications). }\end{array}$} \\
\hline
\end{tabular}

\begin{tabular}{|c|c|c|c|}
\hline \multirow{2}{*}{$\begin{array}{c}\mathrm{k} \\
\text { (quarters) }\end{array}$} & \multicolumn{3}{|c|}{$\begin{array}{l}\text { MALAYSIA: Percentage of the k-step ahead forecast error } \\
\text { variance of domestic output growth explained by: }\end{array}$} \\
\hline & $\begin{array}{l}\text { Exports to } \\
\text { U.S. Shock }\end{array}$ & $\begin{array}{l}\text { Exports to } \\
\text { China Shock }\end{array}$ & $\begin{array}{l}\text { Other } \\
\text { Shocks }\end{array}$ \\
\hline 1 & 8.5 & 2.0 & $89.6^{\star \star}$ \\
\hline 2 & $14.4^{*}$ & 3.4 & $82.1^{\star \star}$ \\
\hline 3 & $20.3^{\star \star}$ & 5.7 & $74.0^{* \star}$ \\
\hline 4 & $20.4^{\star \star}$ & 8.9 & $70.6^{\star \star}$ \\
\hline \multicolumn{4}{|c|}{$\begin{array}{l}\text { NOTES: Results based on a 3-variable VAR consisting of growth of exports to U.S., } \\
\text { growth of exports to China and HK, and domestic growth; sample period } 1993: 2 \text { to } \\
\text { 2006:4, and } 7 \text { lags. A '*' and "***" indicate statistical significance based on } 90 \text { percent } \\
\text { and } 95 \text { percent confidence bands, respectively, computed from Monte Carlo simulations } \\
\text { (5000 replications). }\end{array}$} \\
\hline
\end{tabular}

\begin{tabular}{|c|c|c|c|}
\hline \multirow{2}{*}{$\begin{array}{c}\mathrm{k} \\
\text { (quarters) }\end{array}$} & \multicolumn{3}{|c|}{$\begin{array}{l}\text { PHILIPPINES: Percentage of the k-step ahead forecast error } \\
\text { variance of domestic output growth explained by: }\end{array}$} \\
\hline & $\begin{array}{l}\text { Exports to } \\
\text { U.S. Shock }\end{array}$ & $\begin{array}{l}\text { Exports to } \\
\text { China Shock }\end{array}$ & $\begin{array}{l}\text { Other } \\
\text { Shocks }\end{array}$ \\
\hline 1 & 3.4 & 2.2 & $94.4^{\star \star}$ \\
\hline 2 & 5.9 & 4.3 & $89.8^{\star \star}$ \\
\hline 3 & 8.2 & 6.7 & $85.1^{\star *}$ \\
\hline 4 & $14.9^{*}$ & 8.8 & $76.3^{* \star}$ \\
\hline \multicolumn{4}{|c|}{$\begin{array}{l}\text { NOTES: Results based on a 3-variable VAR consisting of growth of exports to U.S., } \\
\text { growth of exports to China and HK, and domestic growth; sample period 1993:2 to } \\
\text { 2006:4, and } 8 \text { lags. A '*' and “**” indicate statistical significance based on } 90 \text { percent } \\
\text { and } 95 \text { percent confidence bands, respectively, computed from Monte Carlo simulations } \\
\text { (5000 replications). }\end{array}$} \\
\hline
\end{tabular}


Table 1: (continued)

Variance Decompositions based on the estimated VAR

\begin{tabular}{|c|c|c|c|}
\hline \multirow{2}{*}{$\begin{array}{c}\mathrm{k} \\
\text { (quarters) }\end{array}$} & \multicolumn{3}{|c|}{$\begin{array}{l}\text { THAILAND: Percentage of the k-step ahead forecast error } \\
\text { variance of domestic output growth explained by: }\end{array}$} \\
\hline & $\begin{array}{l}\text { Exports to } \\
\text { U.S. Shock }\end{array}$ & $\begin{array}{c}\text { Exports to } \\
\text { China Shock }\end{array}$ & $\begin{array}{l}\text { Other } \\
\text { Shocks }\end{array}$ \\
\hline 1 & 2.0 & 8.9 & $89.1^{\text {** }}$ \\
\hline 2 & 4.7 & $14.2^{*}$ & $81.1^{\text {** }}$ \\
\hline 3 & 11.8 & $16.5^{\star \star}$ & $71.7^{\star \star}$ \\
\hline 4 & $13.3^{*}$ & $17.3^{\star *}$ & $69.4^{* *}$ \\
\hline \multicolumn{4}{|c|}{$\begin{array}{l}\text { NOTES: Results based on a 3-variable VAR consisting of growth of exports to U.S., } \\
\text { growth of exports to China and HK, and domestic growth, sample period 1993:2 to } \\
\text { 2006:3, and } 3 \text { lags. A '*' and "***" indicate statistical significance based on } 90 \text { percent } \\
\text { and } 95 \text { percent confidence bands, respectively, computed from Monte Carlo simulations } \\
\text { (5000 replications). }\end{array}$} \\
\hline
\end{tabular}




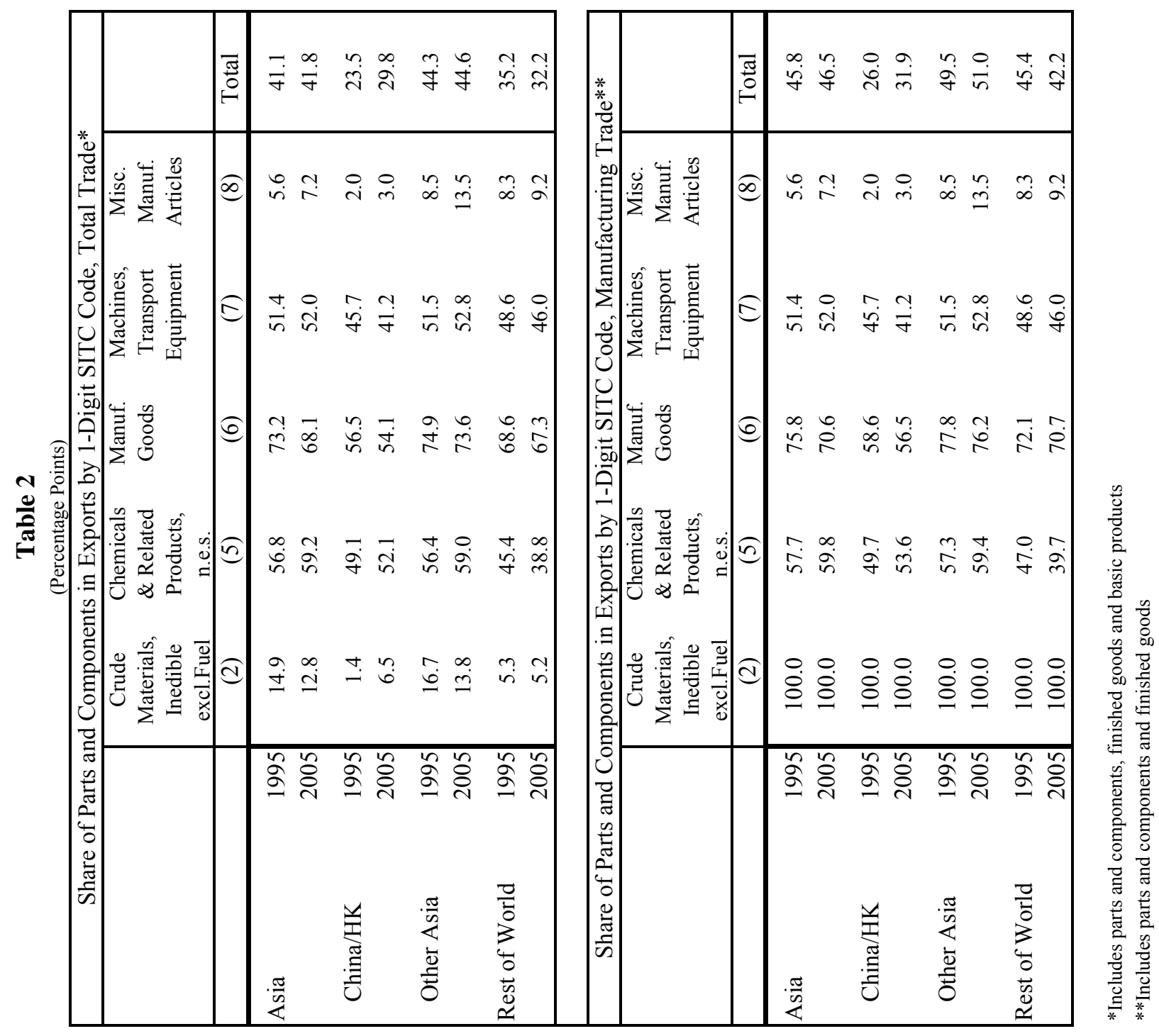




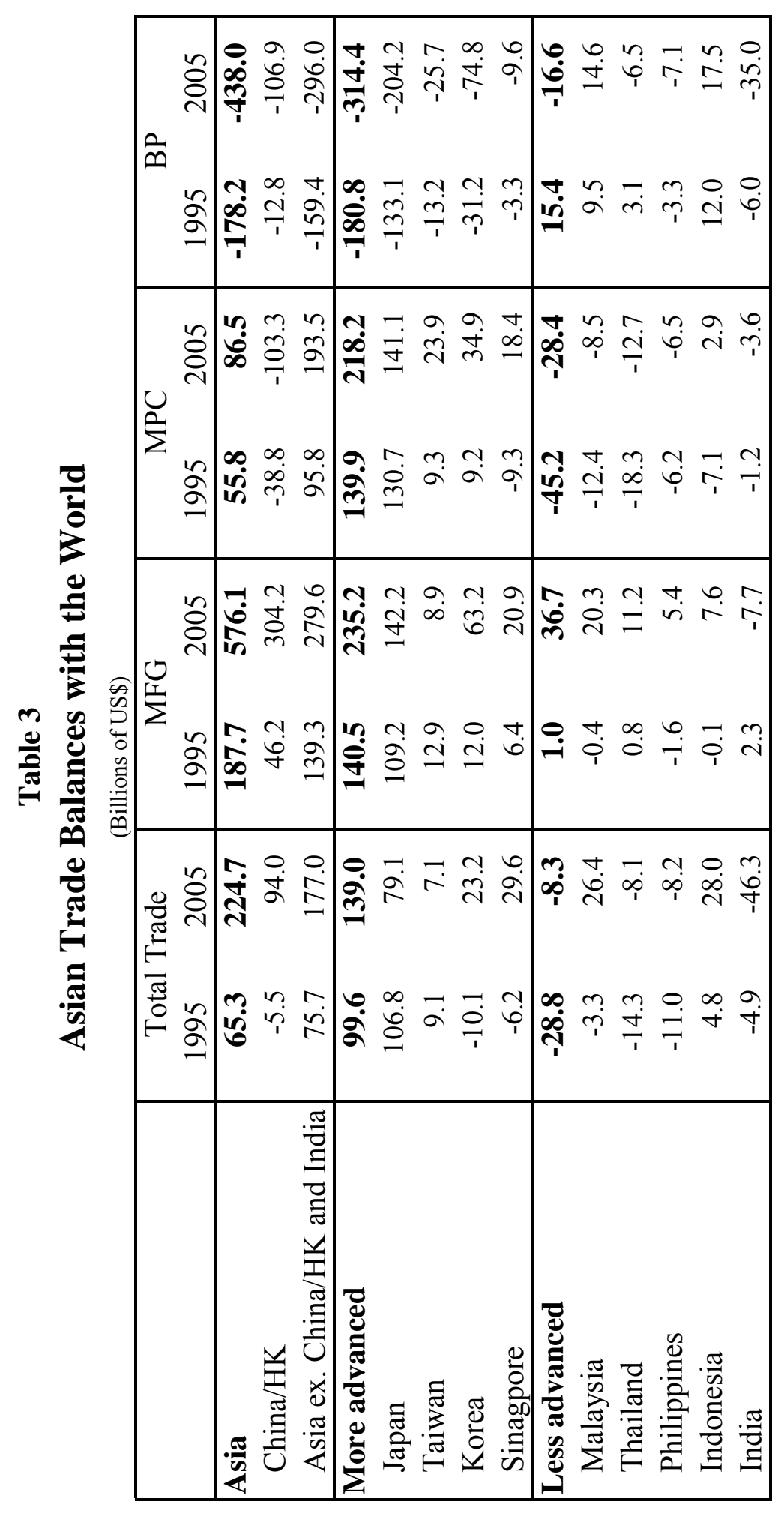


Table 4

Asian Trade Balances with China vs. Rest of the World

(Billions of US\$)

\begin{tabular}{|c|c|c|c|c|c|c|c|c|}
\hline & \multicolumn{8}{|c|}{ China/HK } \\
\hline & \multicolumn{2}{|c|}{ Total Trade } & \multicolumn{2}{|c|}{ MFG } & \multicolumn{2}{|c|}{ MPC } & \multicolumn{2}{|c|}{$\mathrm{BP}$} \\
\hline & 1995 & 2005 & 1995 & 2005 & 1995 & 2005 & 1995 & 2005 \\
\hline Asia ex. China & 54.9 & 110.9 & 10.7 & -10.9 & 46.9 & 116.6 & -2.7 & 5.2 \\
\hline Asia ex. China/HK and India & 54.0 & 112.7 & 10.8 & -6.0 & 45.8 & 117.3 & -2.7 & 1.4 \\
\hline More advanced & 49.1 & 104.3 & 10.6 & -2.9 & 44.8 & 113.5 & -6.3 & -6.2 \\
\hline Japan & 11.0 & 6.0 & -0.4 & -20.7 & 18.8 & 36.0 & -7.4 & -9.3 \\
\hline Taiwan & 21.8 & 45.0 & 6.1 & 12.0 & 16.0 & 33.5 & -0.3 & -0.5 \\
\hline Korea & 11.6 & 36.8 & 3.1 & 6.1 & 9.1 & 32.6 & -0.7 & -2.0 \\
\hline Sinagpore & 4.7 & 16.6 & 1.8 & -0.4 & 0.8 & 11.4 & 2.2 & 5.6 \\
\hline Less advanced & 5.8 & 6.6 & 0.1 & -8.0 & 2.4 & 3.1 & 3.6 & 11.5 \\
\hline Malaysia & 2.5 & 1.5 & 0.5 & -2.0 & 0.9 & 1.6 & 1.1 & 1.9 \\
\hline Thailand & 1.7 & 2.6 & 0.2 & -0.2 & 0.0 & 0.2 & 1.5 & 2.6 \\
\hline Philippines & -1.0 & 2.3 & -0.5 & 0.0 & -0.5 & 2.3 & 0.0 & -0.1 \\
\hline Indonesia & 1.6 & 2.0 & 0.0 & -0.8 & 0.9 & -0.4 & 0.9 & 3.3 \\
\hline \multirow[t]{4}{*}{ India } & 1.0 & -1.9 & -0.1 & -5.0 & 1.1 & -0.7 & 0.0 & 3.8 \\
\hline & \multicolumn{8}{|c|}{ Rest of the World } \\
\hline & \multicolumn{2}{|c|}{ Total Trade } & \multicolumn{2}{|c|}{$\mathrm{MFG}$} & \multicolumn{2}{|c|}{$\mathrm{MPC}$} & \multicolumn{2}{|c|}{$\mathrm{BP}$} \\
\hline & 1995 & 2005 & 1995 & 2005 & 1995 & 2005 & 1995 & 2005 \\
\hline Asia ex. China & 15.9 & 19.8 & 130.8 & 282.8 & 47.8 & 73.3 & -162.7 & -336.3 \\
\hline Asia ex. China/HK and India & 21.8 & 64.3 & 128.4 & 285.6 & 50.0 & 76.2 & -156.7 & -297.5 \\
\hline More advanced & 50.5 & 34.7 & 129.9 & 238.1 & 95.1 & 104.7 & -174.5 & -308.2 \\
\hline Japan & 95.9 & 73.1 & 109.6 & 162.9 & 111.9 & 105.1 & -125.6 & -194.9 \\
\hline Taiwan & -12.8 & -37.9 & 6.8 & -3.1 & -6.7 & -9.6 & -12.8 & -25.2 \\
\hline Korea & -21.6 & -13.6 & 8.9 & 57.0 & 0.0 & 2.2 & -30.6 & -72.8 \\
\hline Sinagpore & -11.0 & 13.0 & 4.6 & 21.3 & -10.1 & 7.0 & -5.5 & -15.2 \\
\hline Less advanced & -34.6 & -14.8 & 0.9 & 44.7 & -47.3 & -31.5 & 11.8 & -28.1 \\
\hline Malaysia & -5.8 & 24.9 & -0.9 & 22.3 & -13.3 & -10.1 & 8.4 & 12.6 \\
\hline Thailand & -16.1 & -10.7 & 0.6 & 11.4 & -18.3 & -12.9 & 1.6 & -9.1 \\
\hline Philippines & -10.0 & -10.5 & -1.1 & 5.4 & -5.7 & -8.8 & -3.3 & -7.1 \\
\hline Indonesia & 3.2 & 25.9 & -0.1 & 8.4 & -7.8 & 3.3 & 11.1 & 14.2 \\
\hline India & -5.8 & -44.5 & 2.4 & -2.8 & -2.2 & -3.0 & -6.0 & -38.8 \\
\hline
\end{tabular}




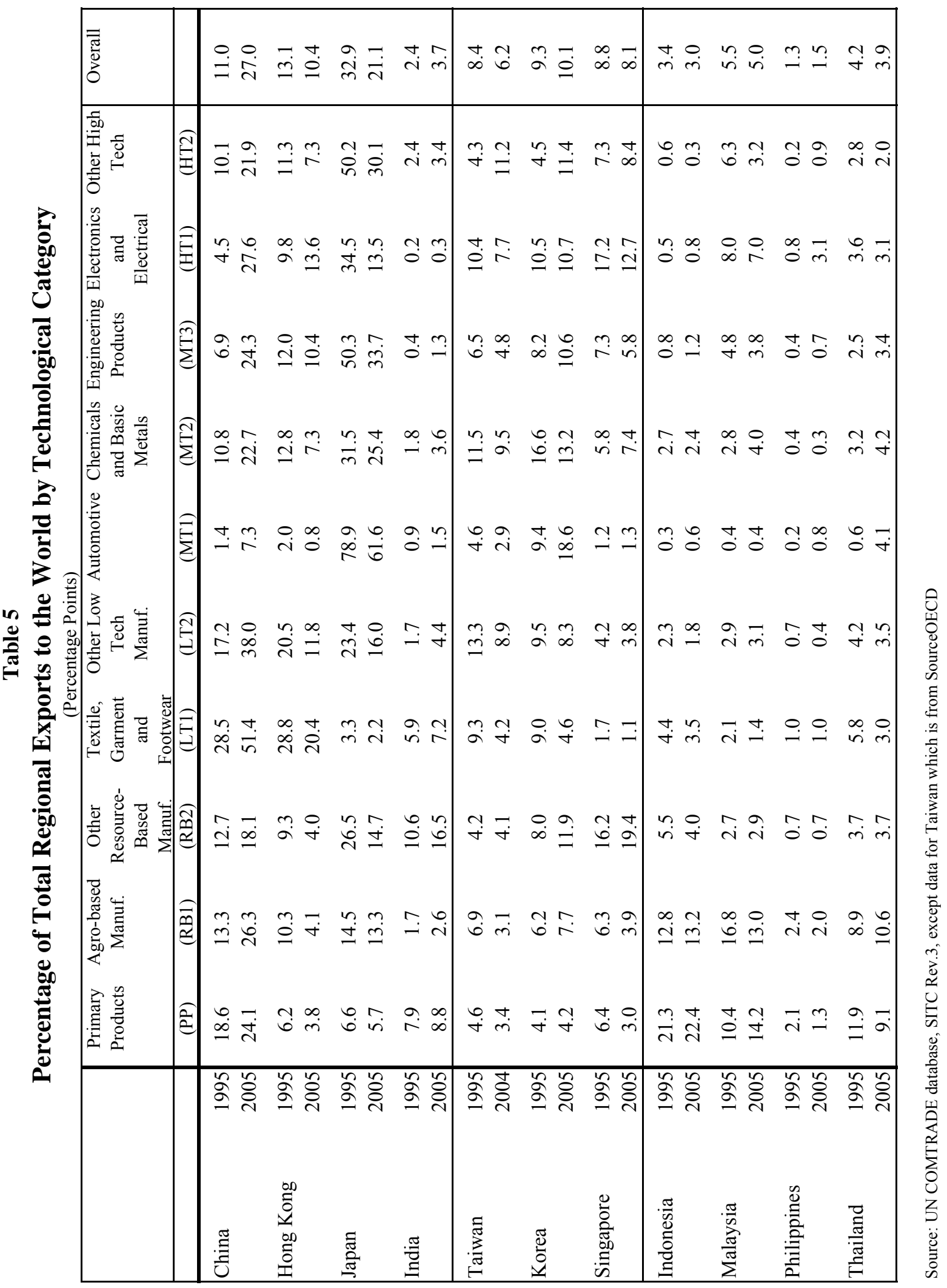




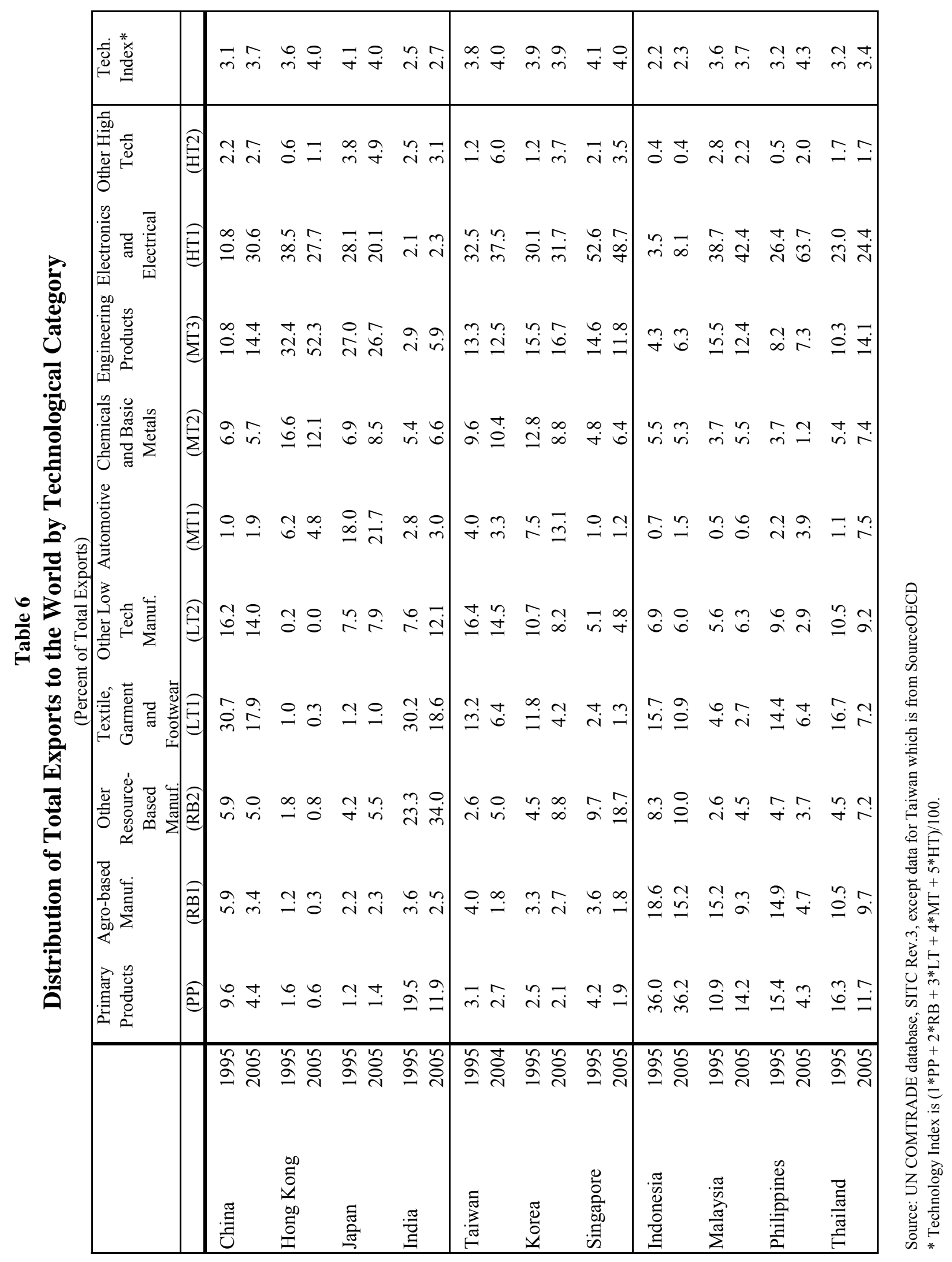


Table 7

\section{Effect of Competition from China on Total Exports}

\begin{tabular}{|c|c|c|c|c|c|c|c|c|c|}
\hline \multicolumn{10}{|c|}{ (Percent) } \\
\hline \multicolumn{3}{|c|}{ Estimation of $\alpha_{3}$ in: } & \multicolumn{7}{|c|}{$\frac{\chi_{p t+1}-\chi_{p t}}{\chi_{p t}}=\alpha_{0}+\sum \alpha_{1 t}$ year ${ }_{t}+\alpha_{2} \ln \left(\chi_{p t-1}\right)+\alpha_{3} V_{p t-1}+\varepsilon_{p t}$} \\
\hline & India & Indon. & Japan & Malay. & Philip. & S. Korea & Singap. & Taiwan & Thail. \\
\hline All tech. products & -0.02 & $0.14 * *$ & $-0.16^{* *}$ & $-0.18^{* *}$ & $0.21 * *$ & $-0.26 * *$ & $-0.14^{* *}$ & $-0.24 * *$ & -0.01 \\
\hline High-tech 1 (HT1) & -0.10 & 0.20 & $-0.38^{* *}$ & 0.12 & -0.04 & -0.22 & -0.03 & 0.01 & $-0.12 * *$ \\
\hline High-tech 2 (HT2) & -0.46 & 0.12 & -0.11 & $-0.57 * *$ & $1.04 * *$ & -0.05 & 0.01 & -0.12 & -0.42 \\
\hline Mid-tech 1 (MT1) & 0.06 & 0.56 & $-0.68^{* *}$ & -0.20 & -0.04 & $-1.62 * *$ & -0.47 & 0.22 & 0.01 \\
\hline Mid-tech 2 (MT2) & $-0.33^{*}$ & -0.25 & -0.12 & -0.34 & -0.01 & $-0.46^{* *}$ & -0.28 & $-0.34 * *$ & -0.09 \\
\hline Mid-tech 3 (MT3) & $-0.28 * *$ & -0.24 & $-0.30^{* *}$ & -0.04 & -0.26 & $-0.35 * *$ & $-0.16^{* *}$ & $-0.31 * *$ & 0.15 \\
\hline Low-tech 1 (LT1) & 0.04 & $0.16^{*}$ & $-0.07 * *$ & 0.04 & $0.27 * *$ & $-0.14 * *$ & 0.01 & $-0.12^{* *}$ & -0.04 \\
\hline Low-tech 2 (LT2) & $-0.15^{* *}$ & 0.07 & $-0.10^{* *}$ & $-0.25 * *$ & 0.08 & $-0.22 * *$ & $-0.13^{* *}$ & $-0.22 * *$ & -0.01 \\
\hline
\end{tabular}

$\frac{\chi_{p t+1}-\chi_{p t}}{\chi_{p t}}$ : export growth of commodity $p$ at the 5-digit SITC Rev.3 level at time $t$.

$V_{p t}$ : China's export as a share of regional exports.

Sample is annual data from 1990 through 2005.

*, ** indicates significance at the 10 and 5 percent levels, respectively.

Estimates of $\alpha_{2}$ were all negative and statistically significant.

Estimations include yearly dummy variables. Adjusted $-\mathrm{R}^{2}$ generally varied between 0.03 and 0.20 . 
Gross Domestic Product

\section{Chart 1}

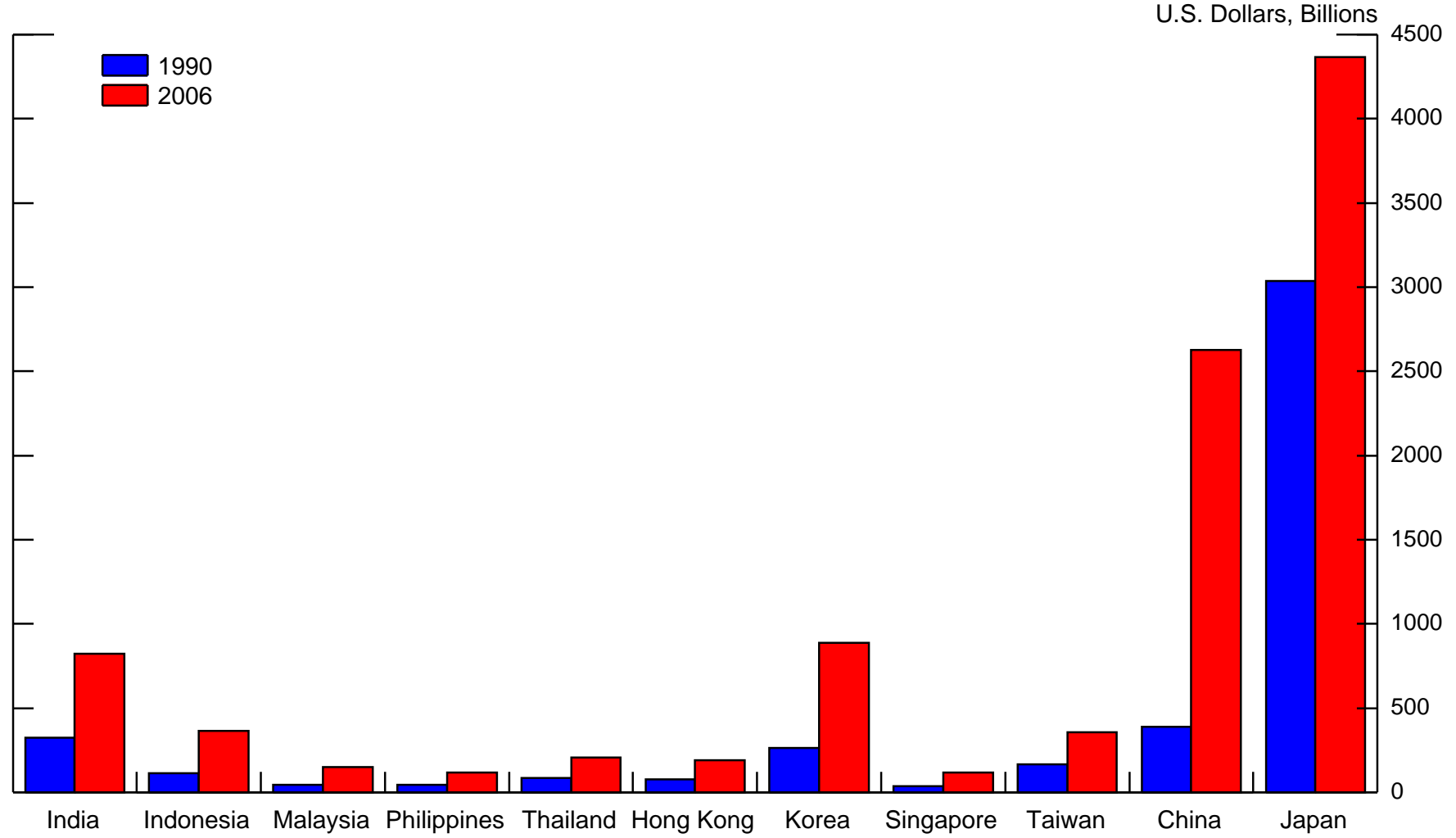

PPP GDP Per Capita

\section{Chart 2}




\section{Chart 3}

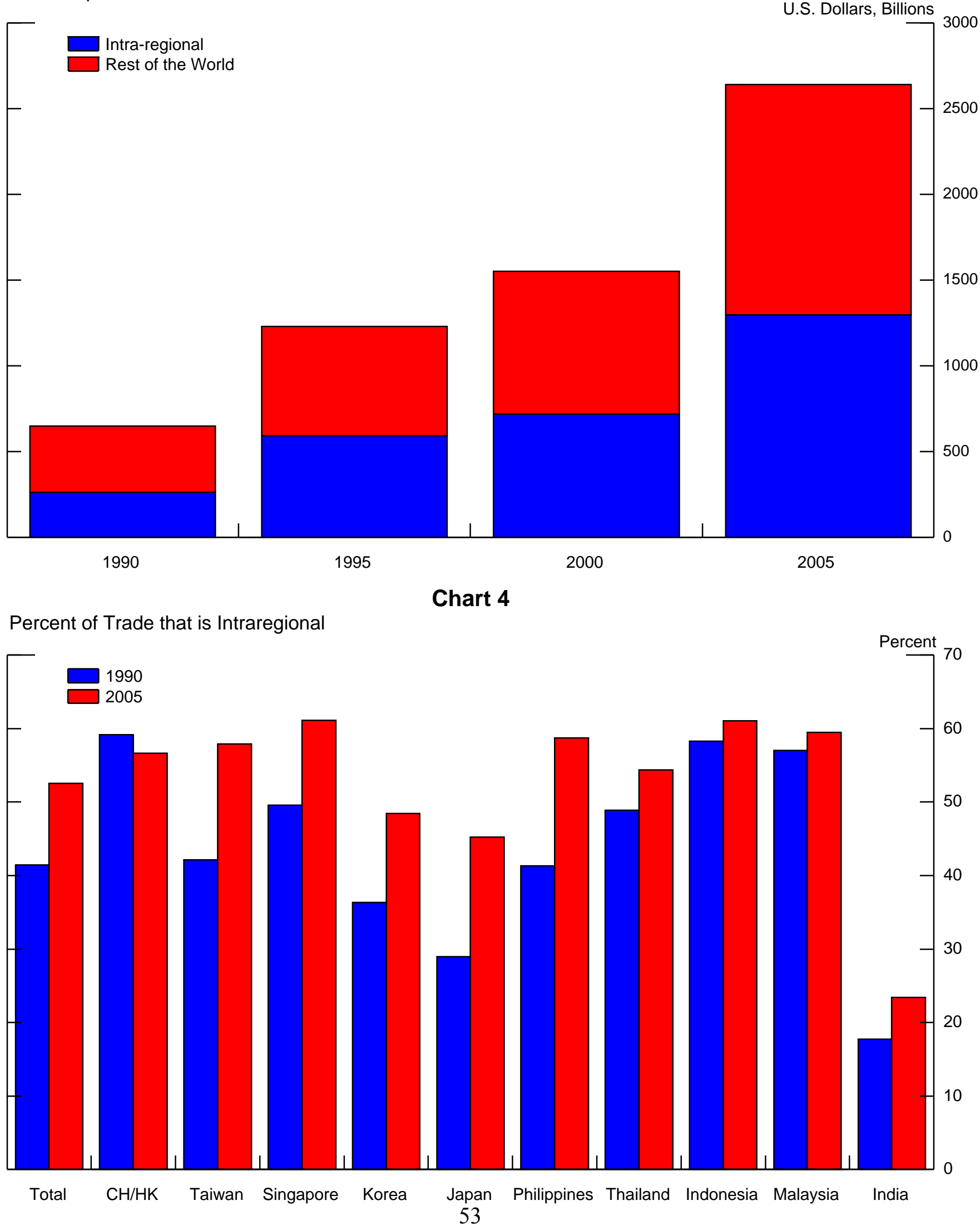


Real Exports as a Percent of GDP

\section{Chart 5}

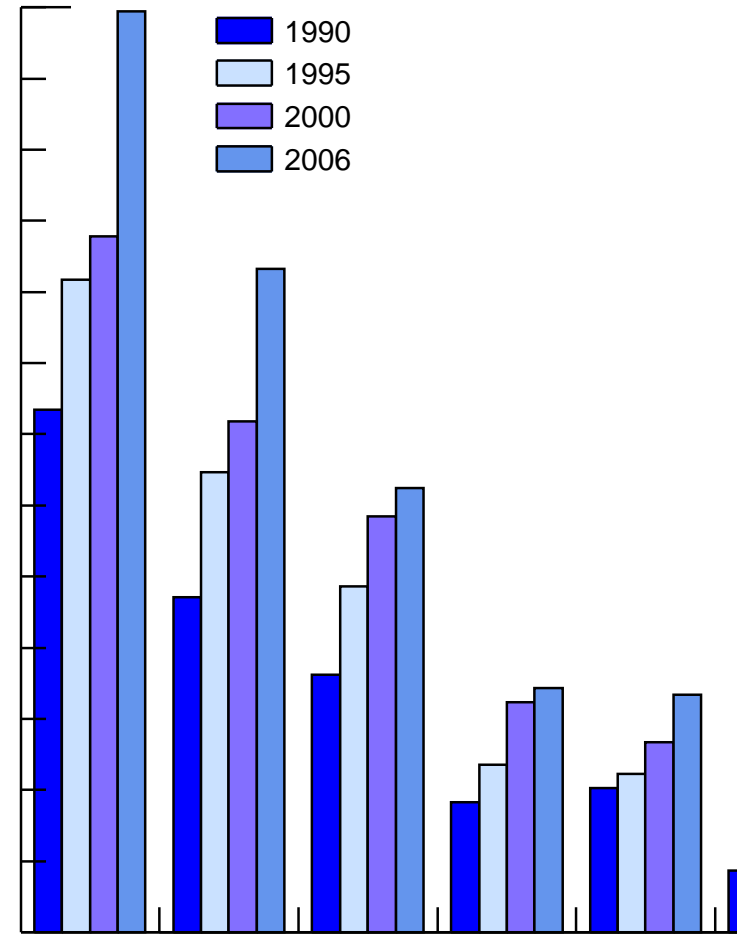

SingaporeHong Kong Malaysia Thailand Taiwan * U.S. Dollars

Percentage Point Contribution of Real Net Exports to GDP Growth

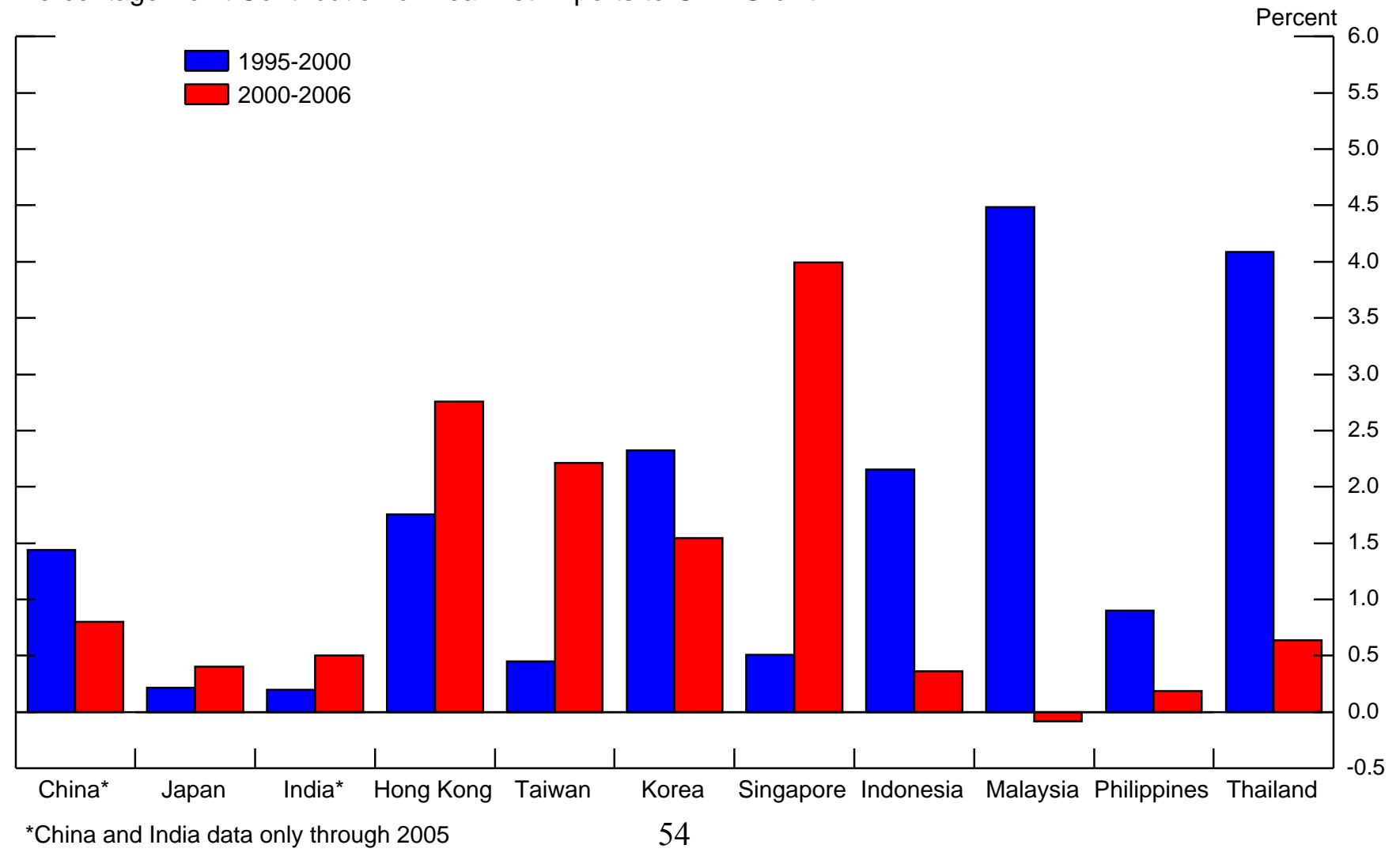




\section{Chart 7}

Average Annual Rates of Real GDP Growth

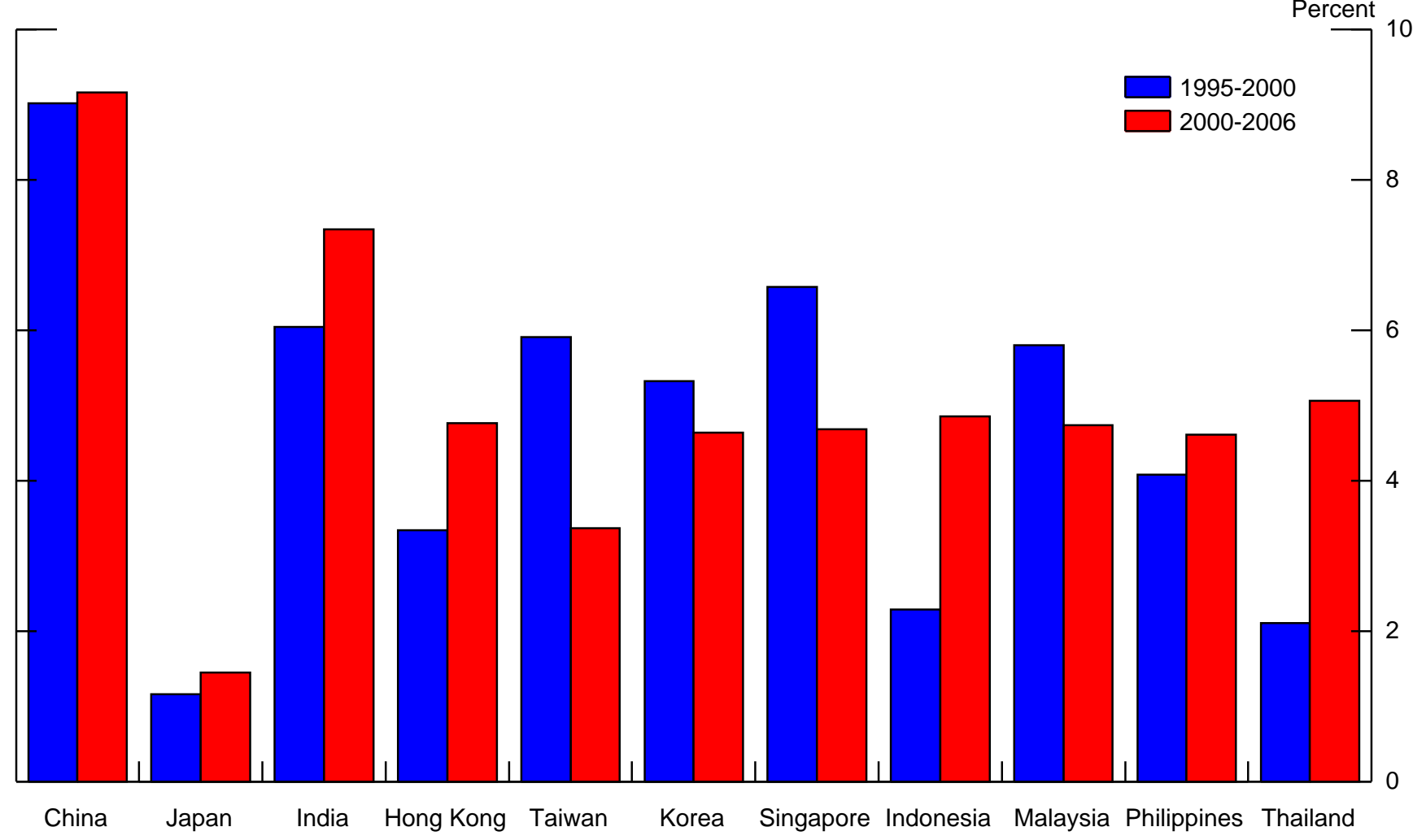


Chart 8

\section{Coefficients from Growth Regressions*}

Thailand

China

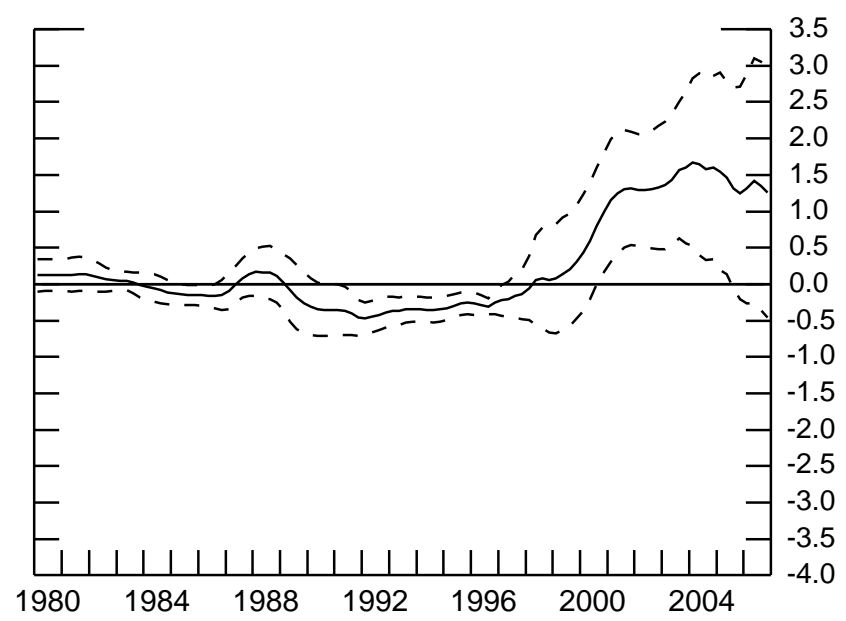

United States

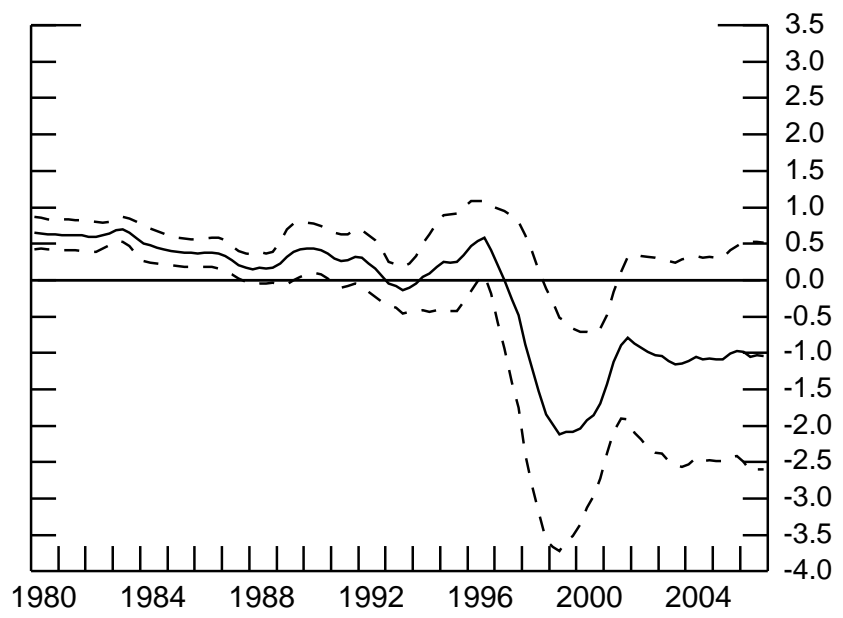

China

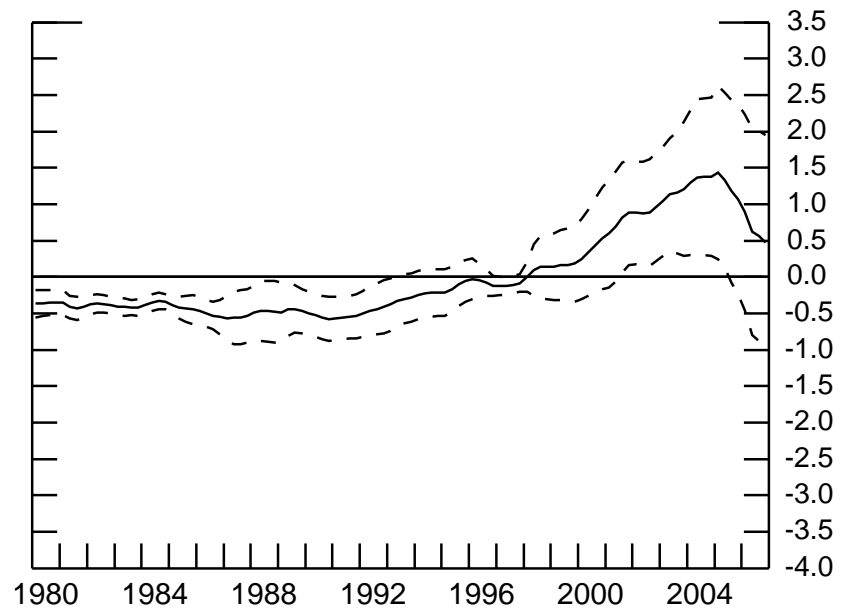

\section{Malaysia}

United States

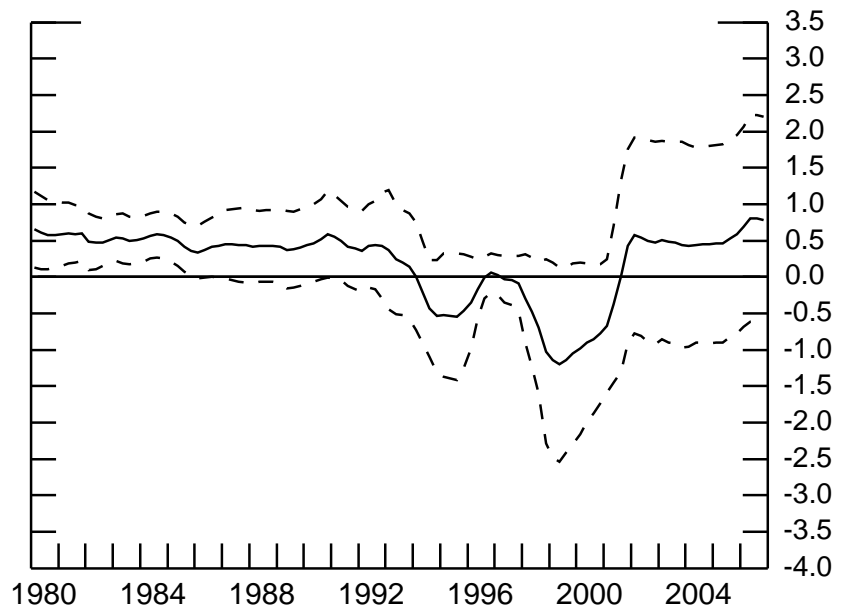

\section{India}

\section{China}

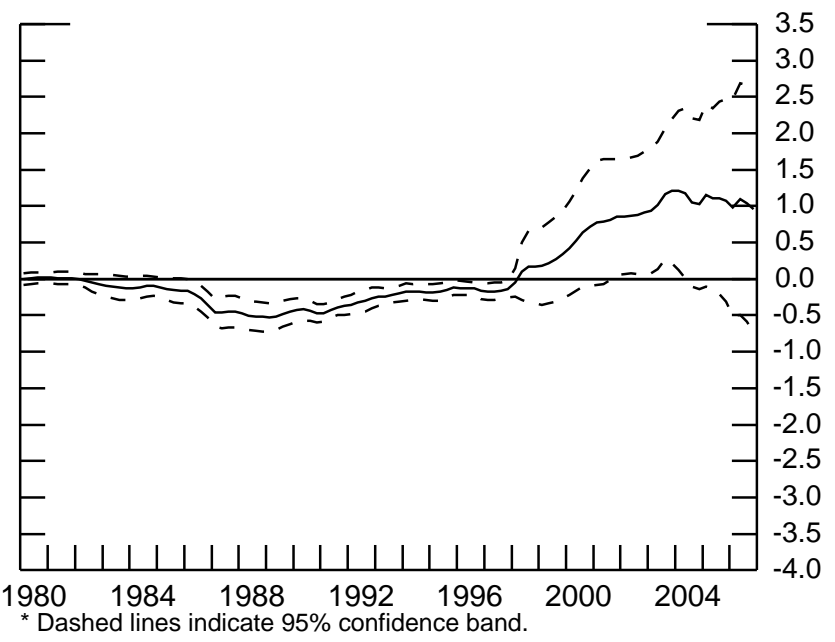

United States

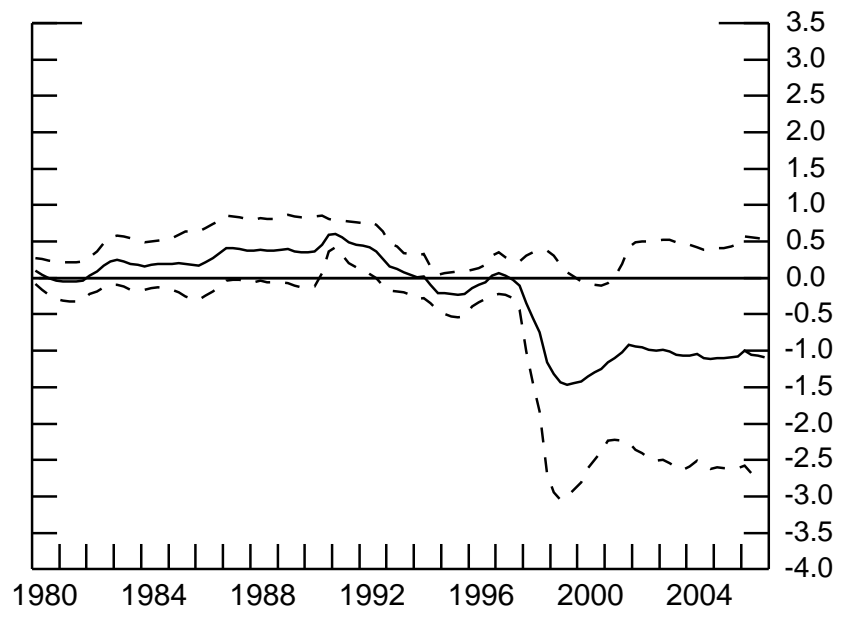


Chart 9

\section{Coefficients from Growth Regressions (cont'd)*}

\section{Philippines}

China

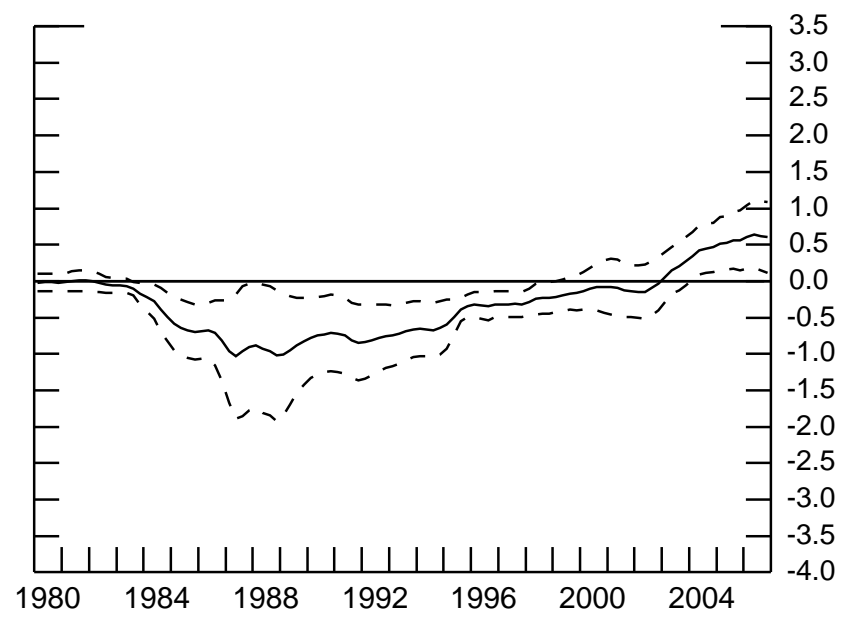

United States

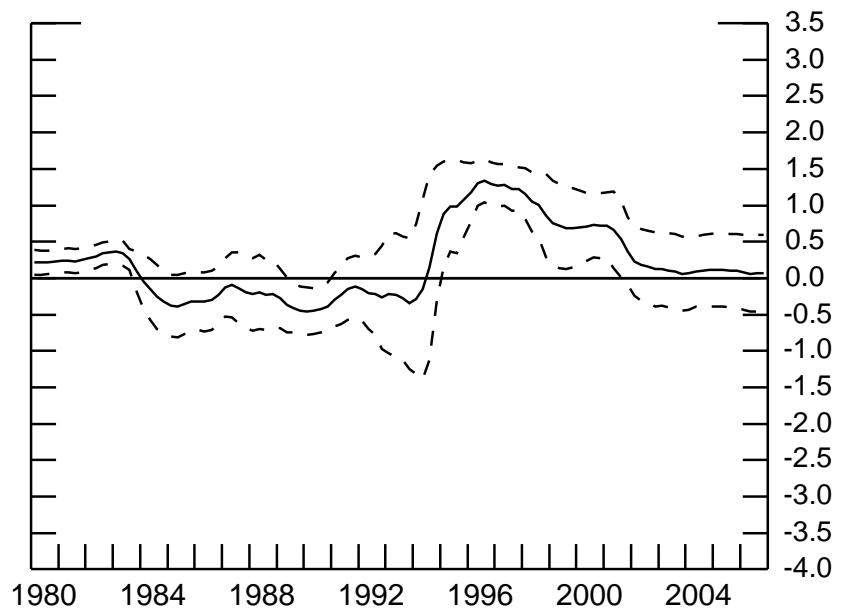

China

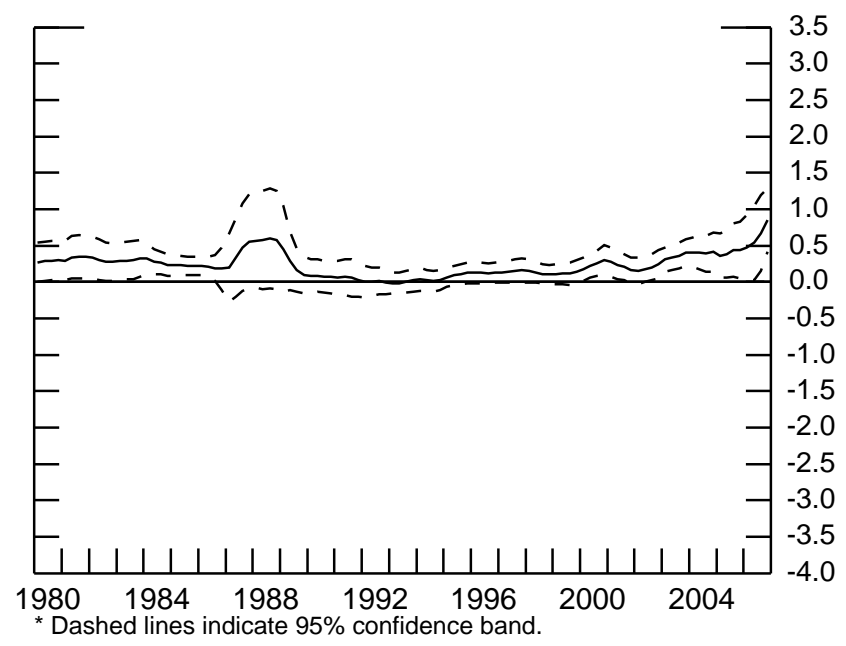

Indonesia

United States

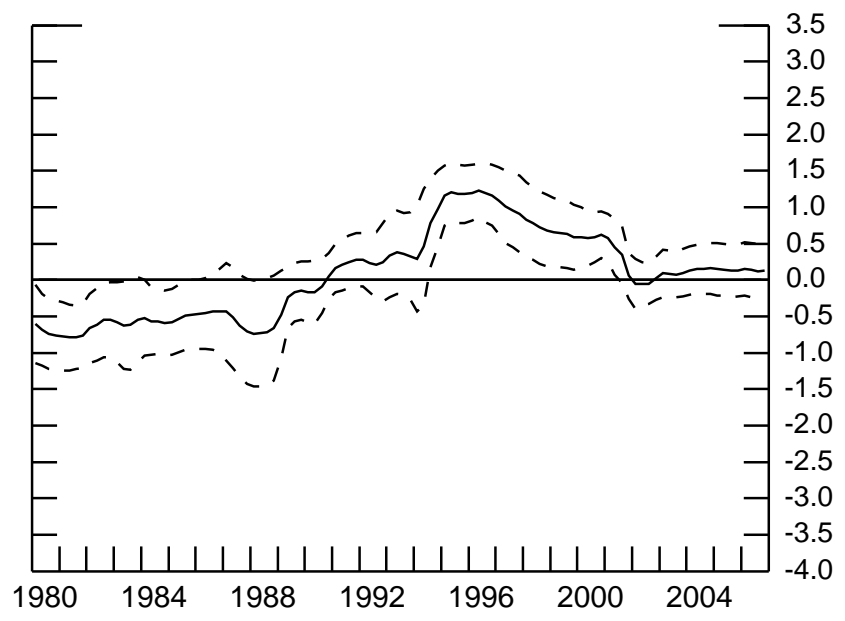


Chart 10

\section{Coefficients from Growth Regressions (cont'd)*}

China

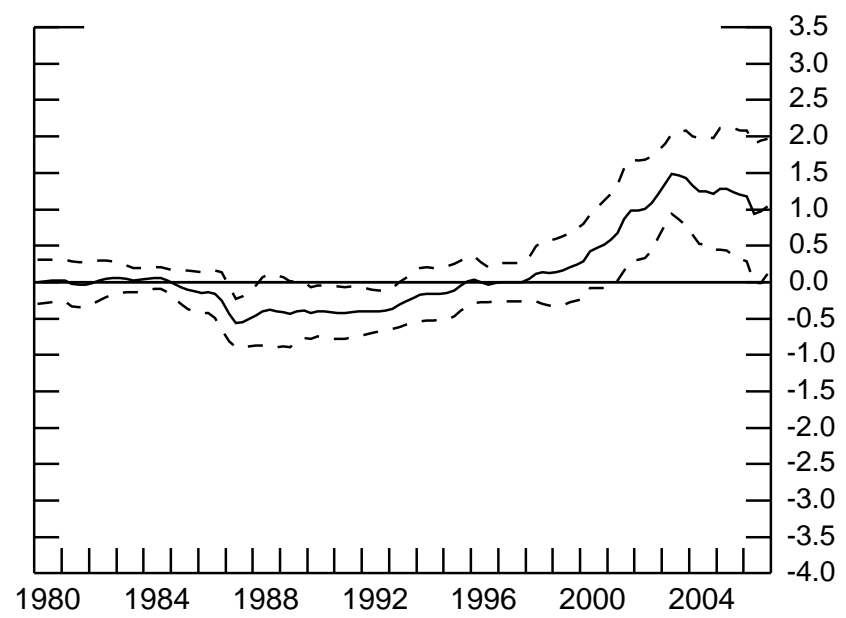

Singapore

United States

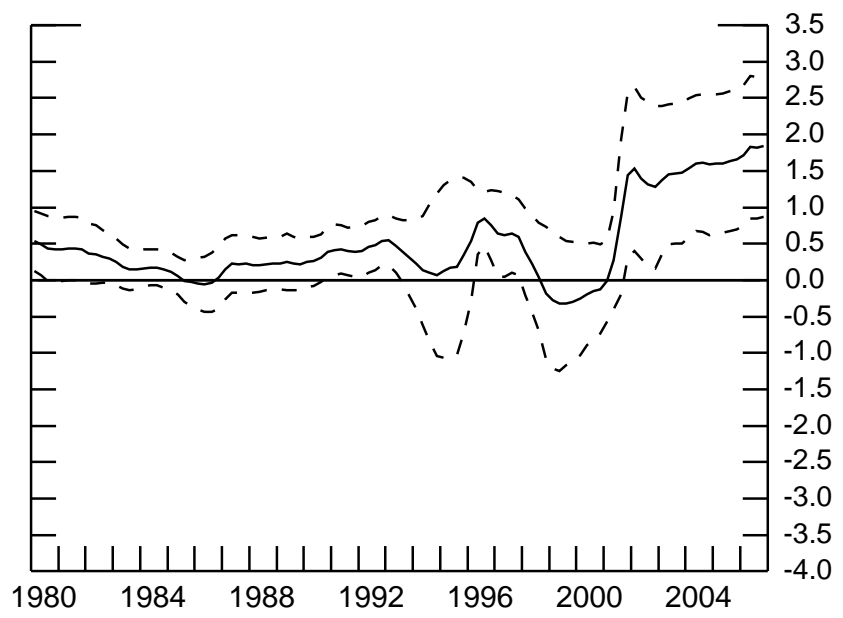

Taiwan

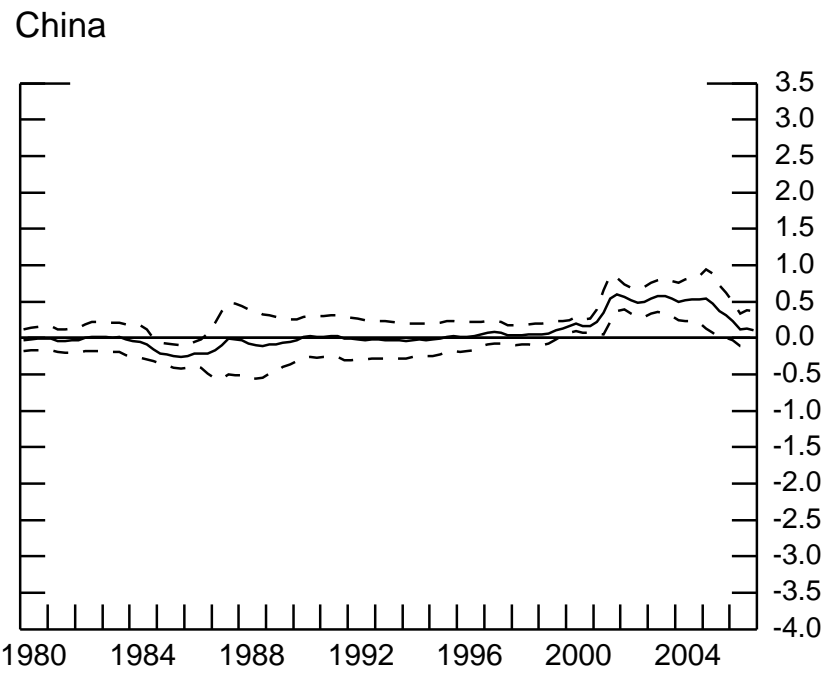

United States

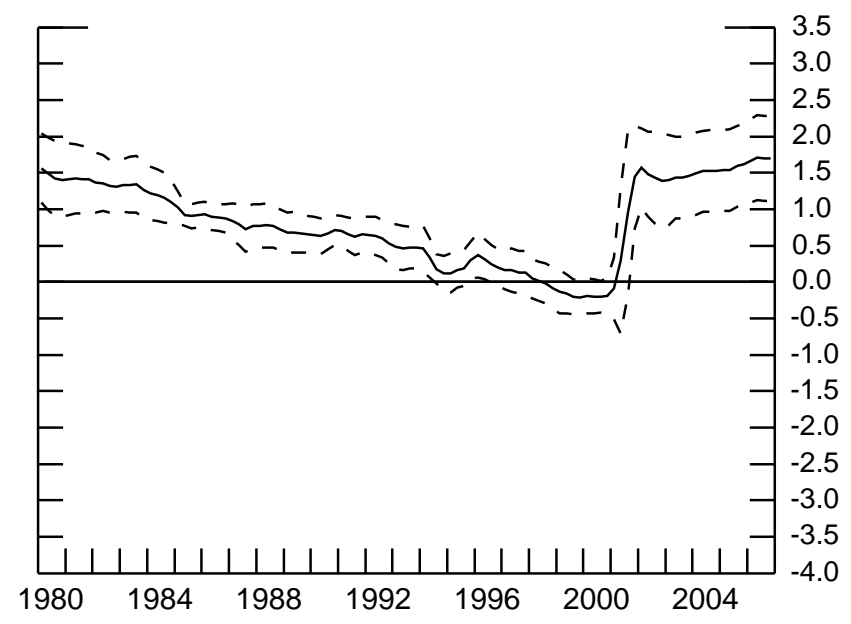

China

\section{Hong Kong}

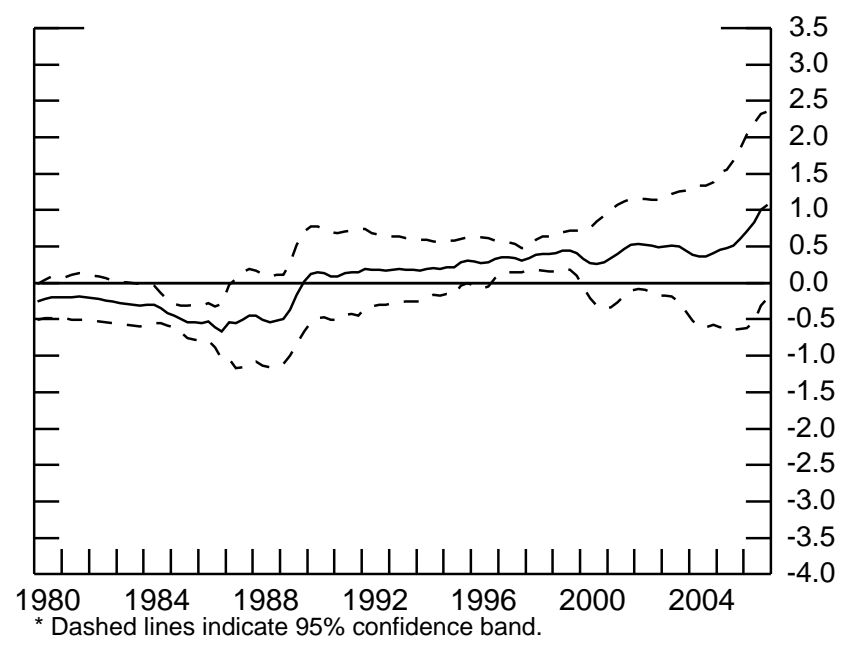

United States

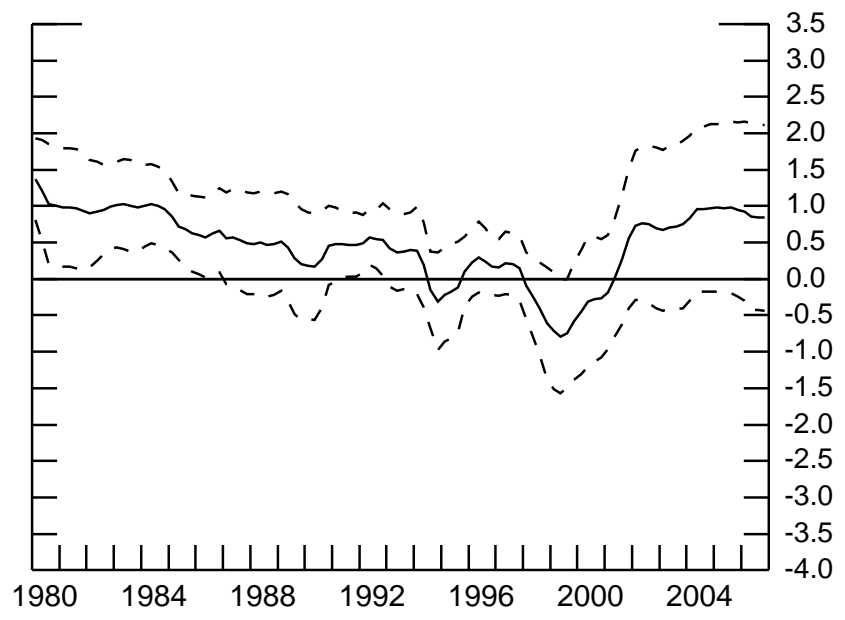


Chart 11

\title{
Coefficients from Growth Regressions (cont'd) ${ }^{\star}$
}

China

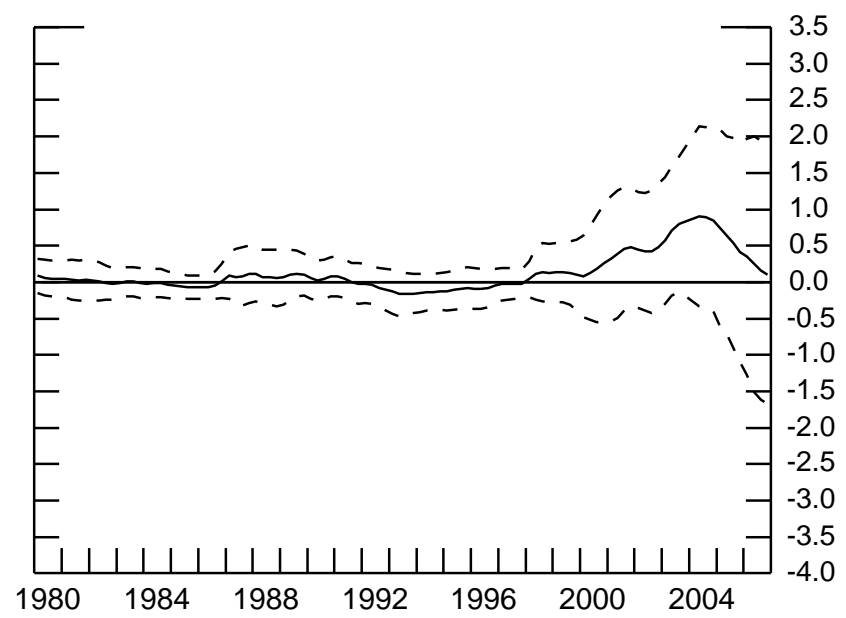

Korea

\author{
United States
}

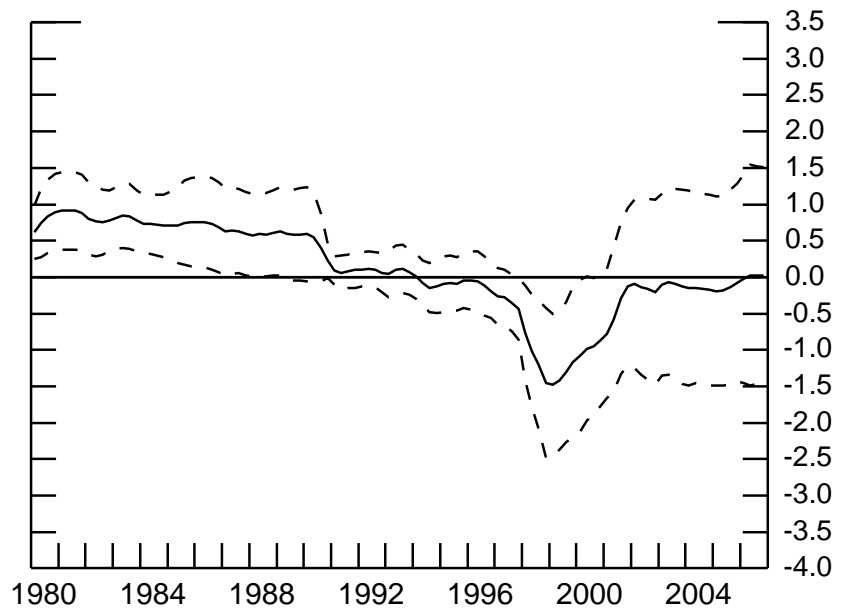

\section{Japan}

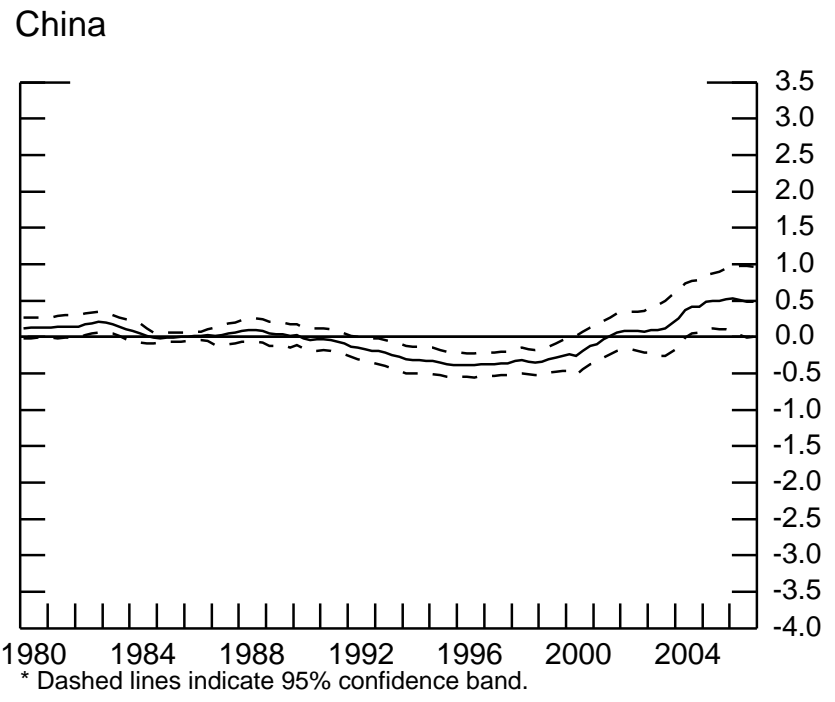

United States

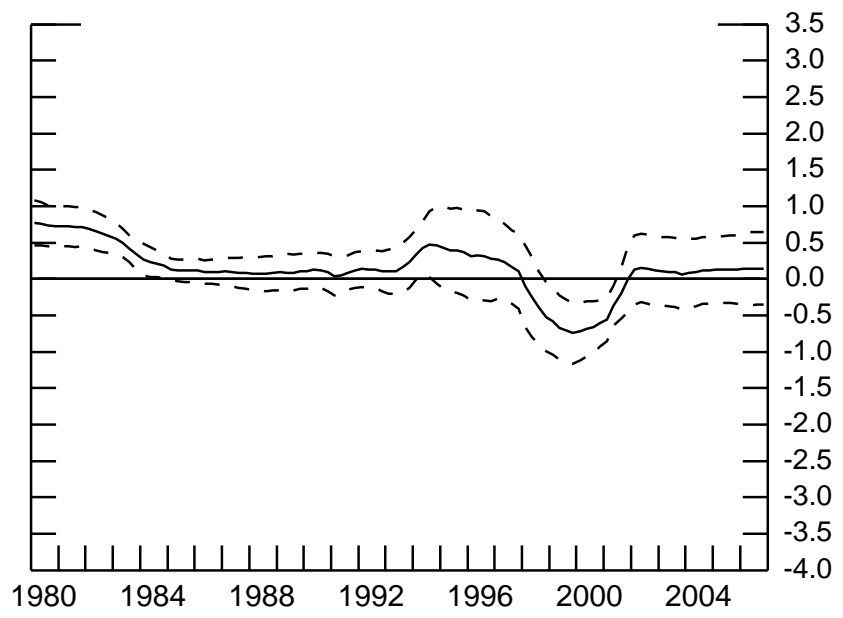




\section{Chart 12: Impulse Responses using structural VAR (NIEs)}
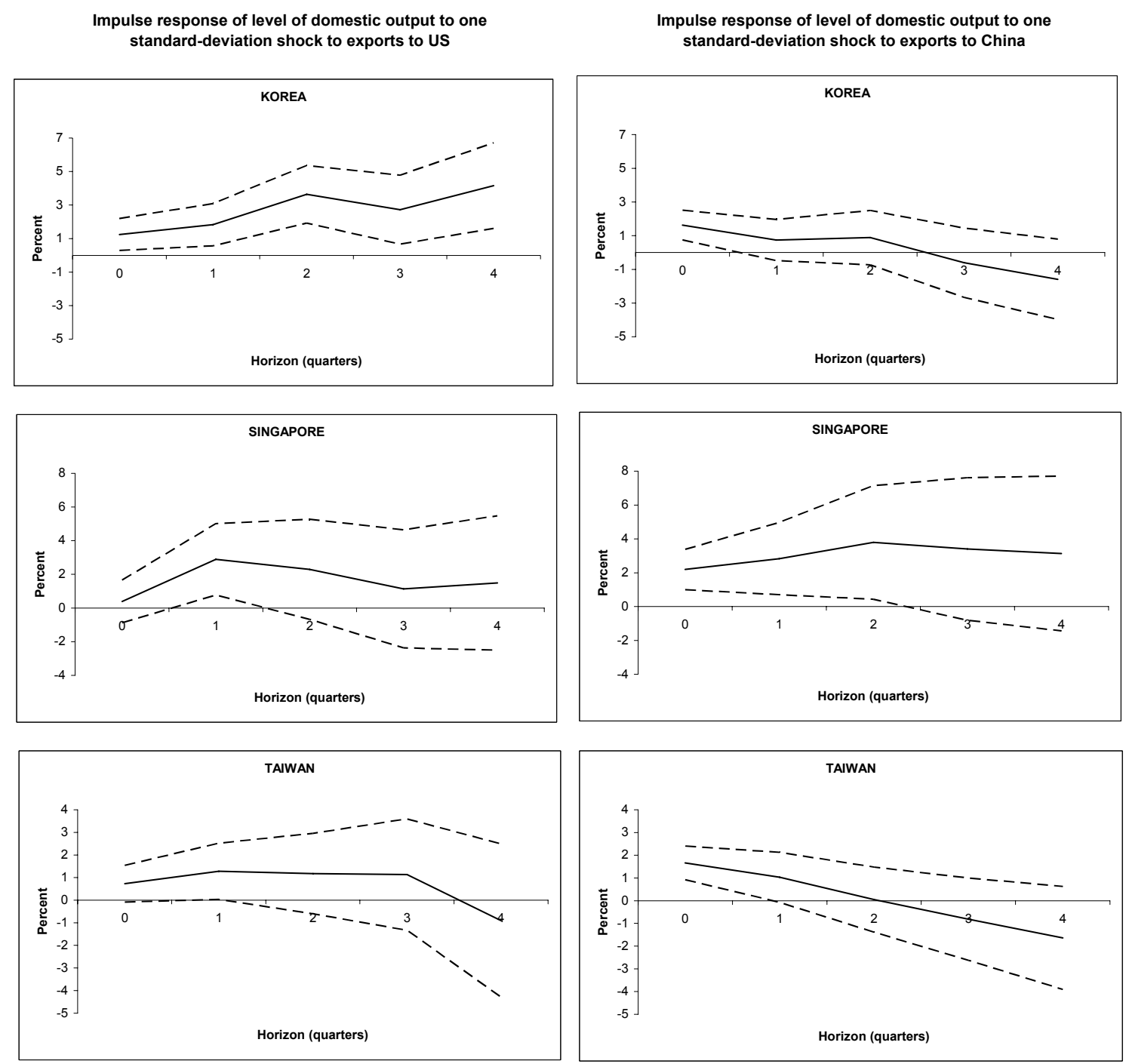


\section{Chart 13: Impulse Responses using structural VAR (ASEAN4)}
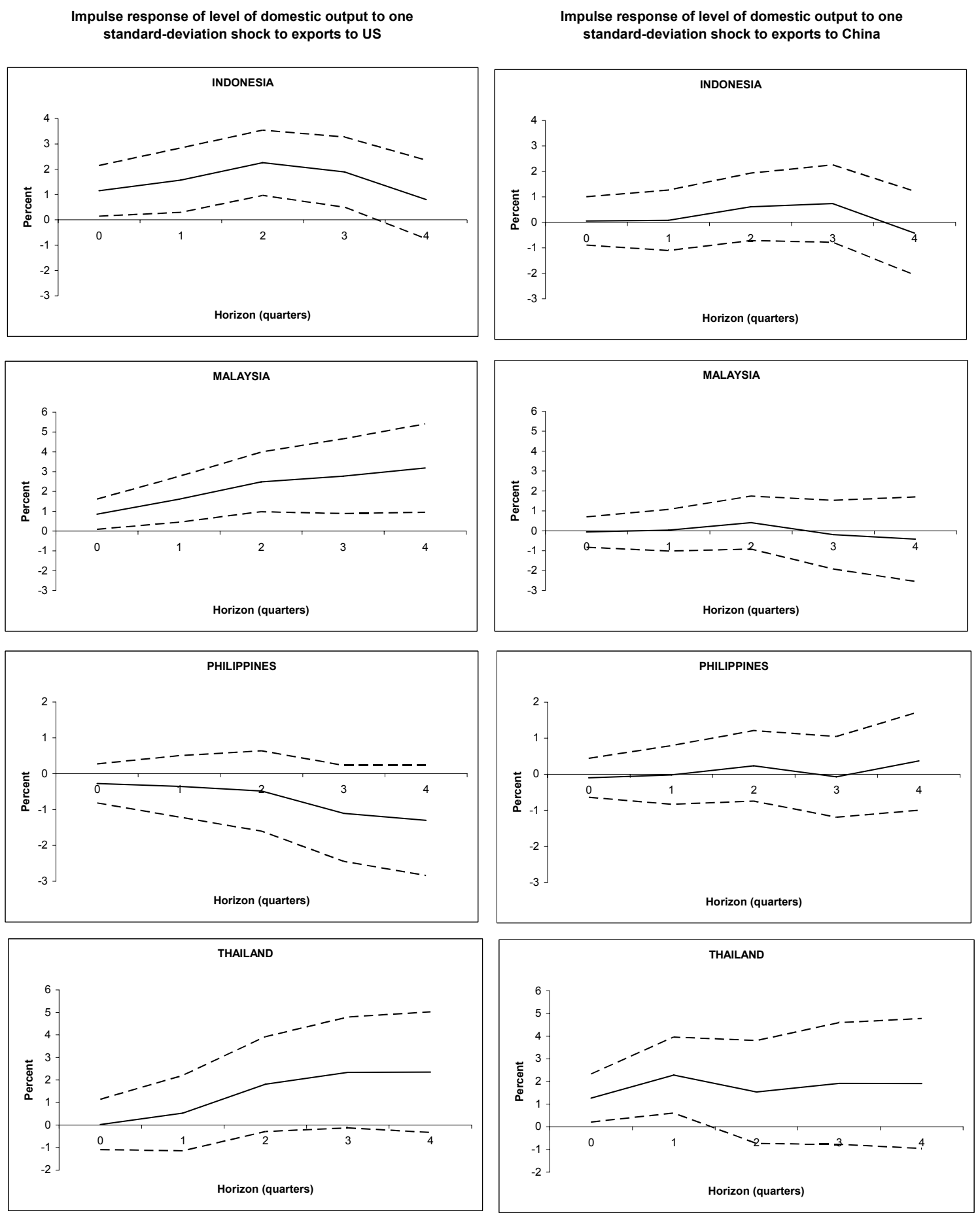
Chart 14

Parts and Components as a Percent of Exports of Manufactured Goods: 2005

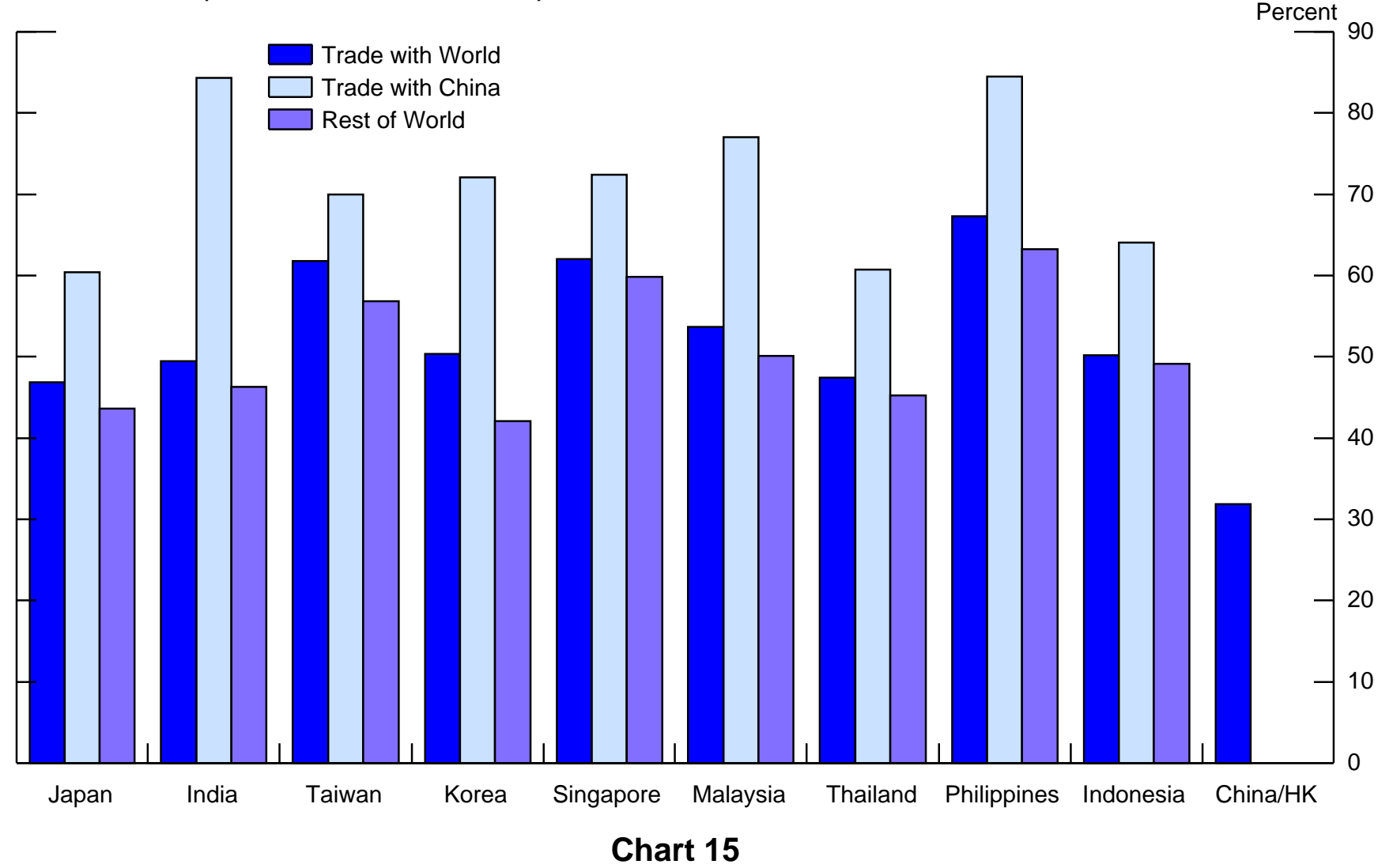

Parts and Components as a Percent of Imports of Manufactured Goods: 2005

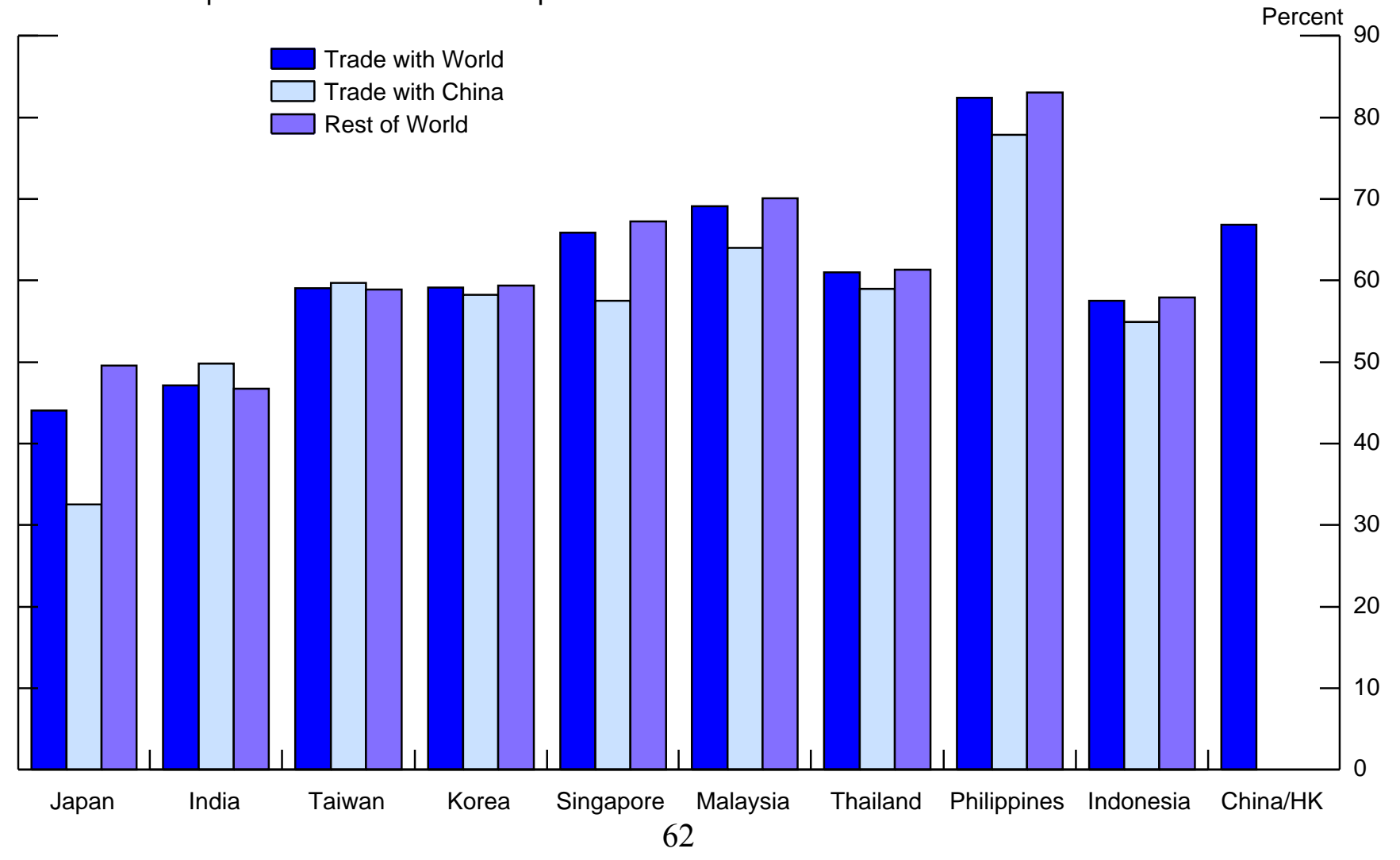




\section{Chart 16}

Parts and Components as a Percent of Trade in Manufactured Goods: 2005

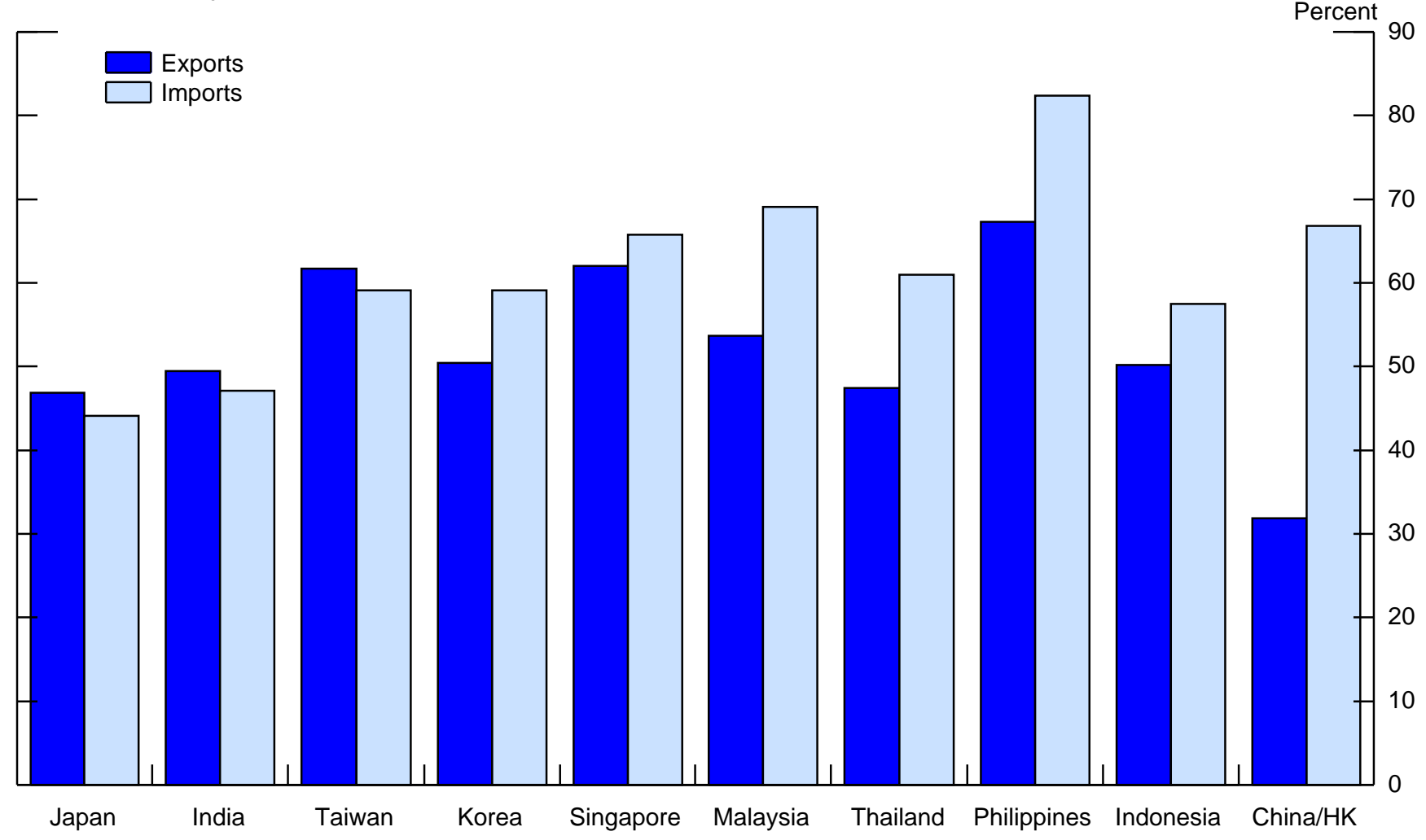




\section{Chart 17}

Asia

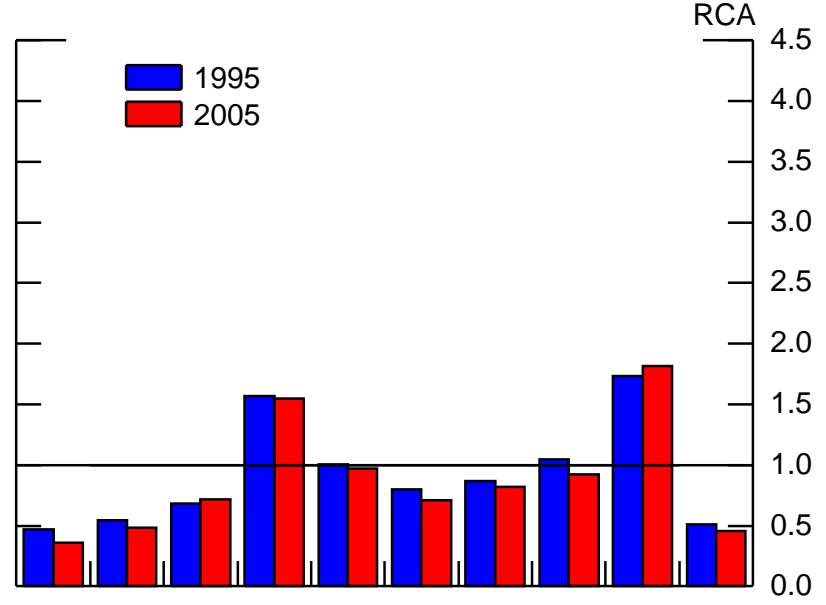

PP RB1 RB2 LT1 LT2 MT1 MT2 MT3 HT1 HT2

Hong Kong

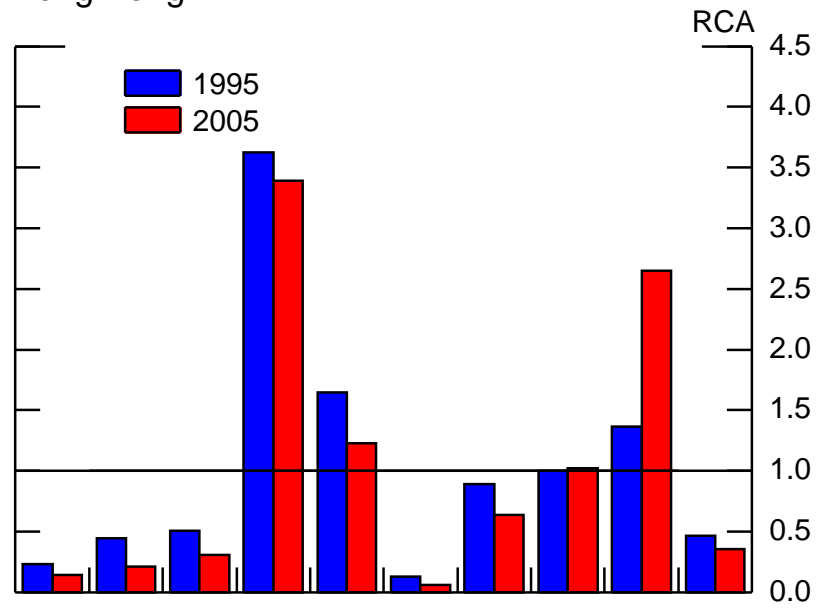

PP RB1 RB2 LT1 LT2 MT1 MT2 MT3 HT1 HT2

Japan

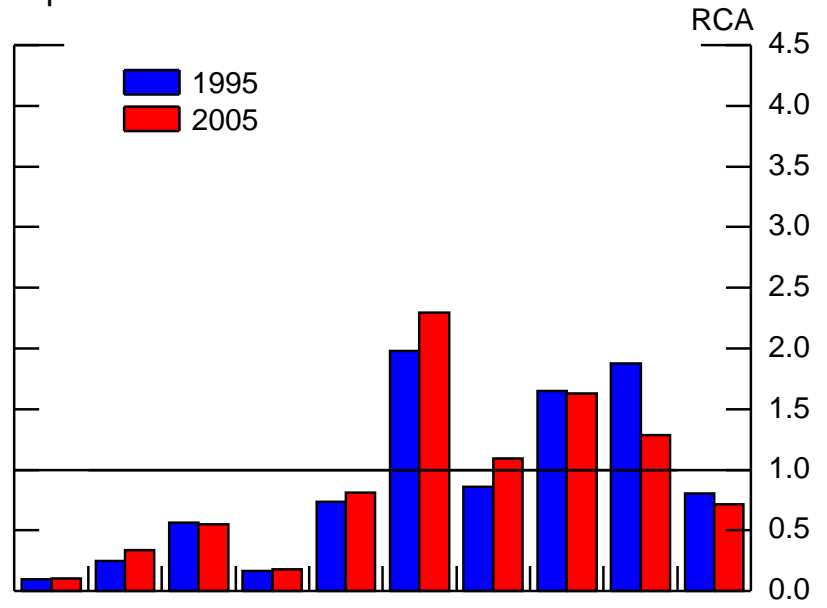

PP RB1 RB2 LT1 LT2 MT1 MT2 MT3 HT1 HT2

\section{China}

China

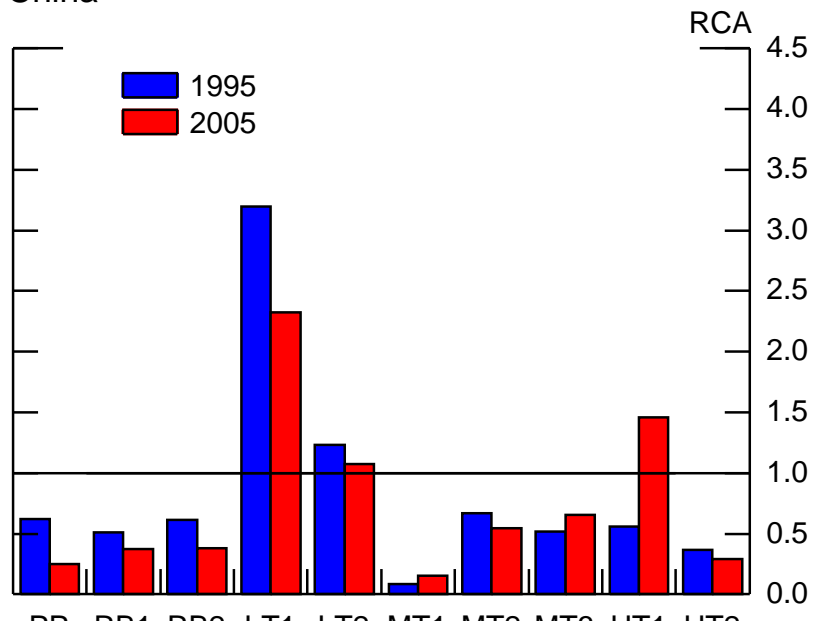

PP RB1 RB2 LT1 LT2 MT1 MT2 MT3 HT1 HT2

Taiwan

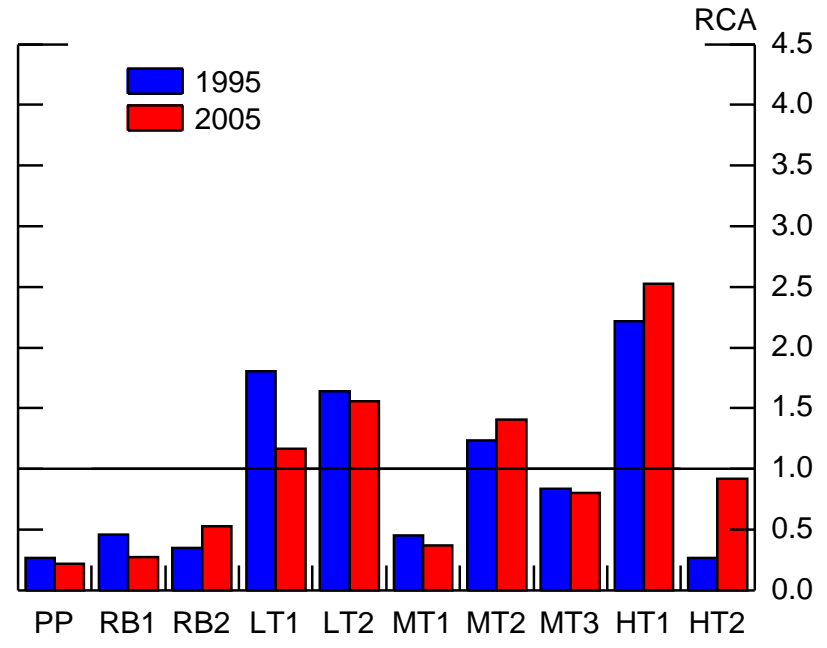

Korea

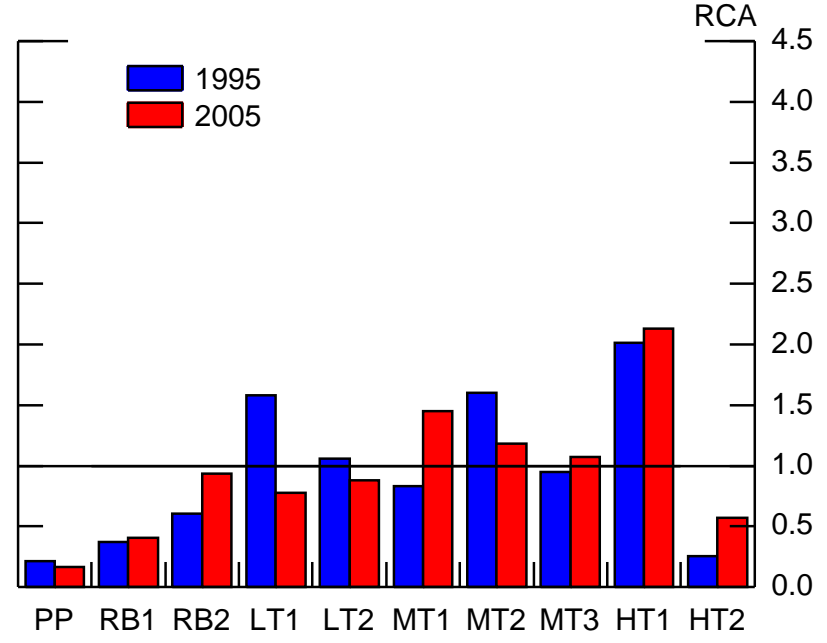




\section{Chart 18}

Singapore

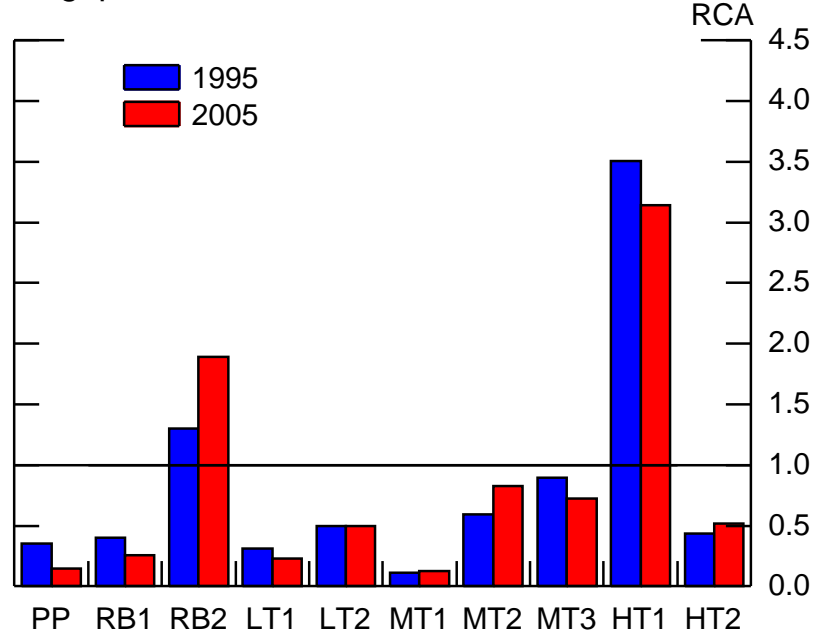

Philippines

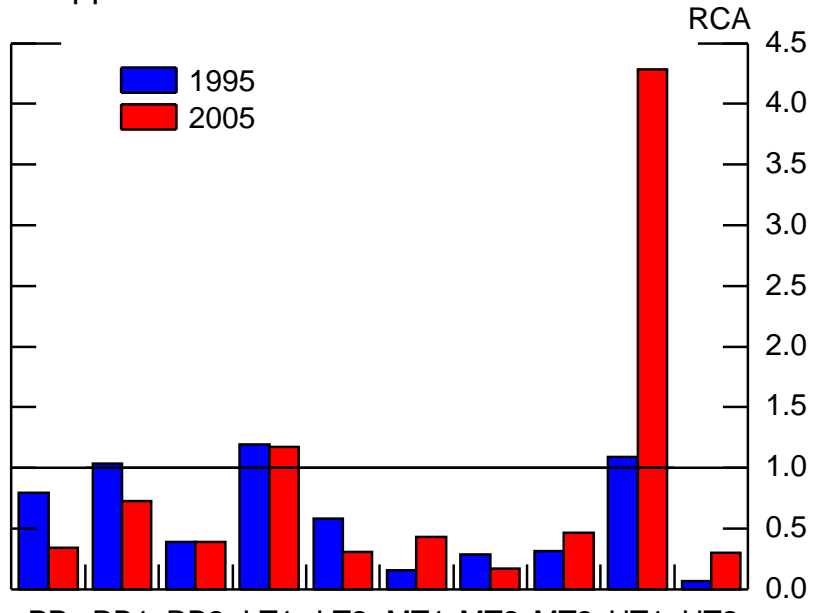

PP RB1 RB2 LT1 LT2 MT1 MT2 MT3 HT1 HT2

Indonesia

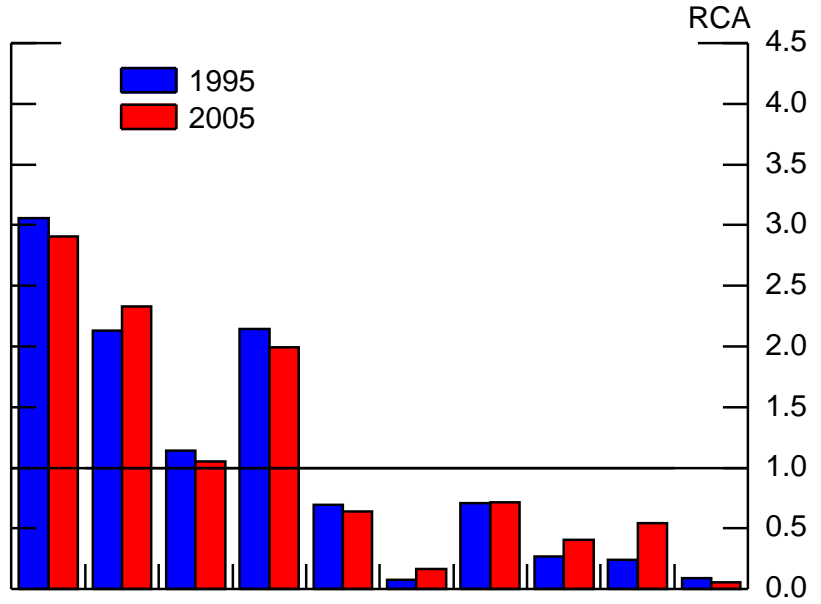

PP RB1 RB2 LT1 LT2 MT1 MT2 MT3 HT1 HT2
Advantage

Malaysia

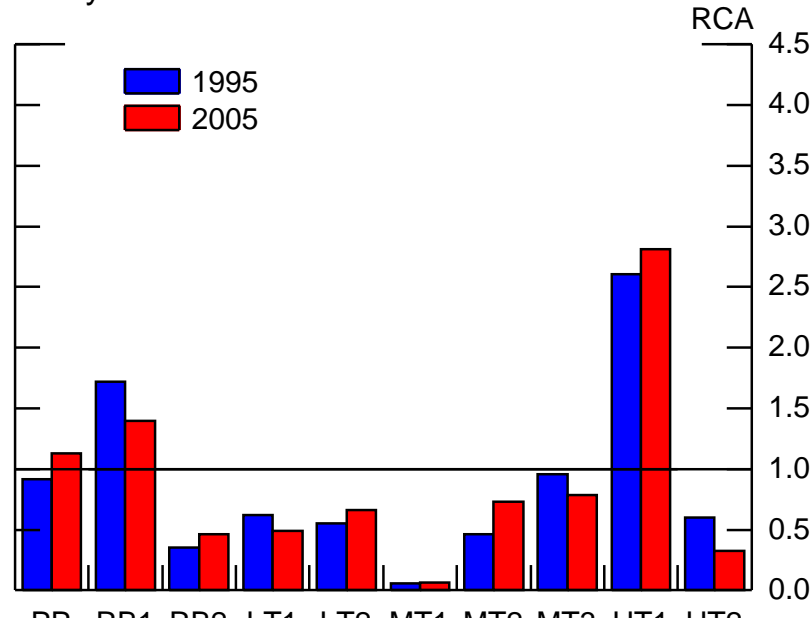

PP RB1 RB2 LT1 LT2 MT1 MT2 MT3 HT1 HT2

Thailand

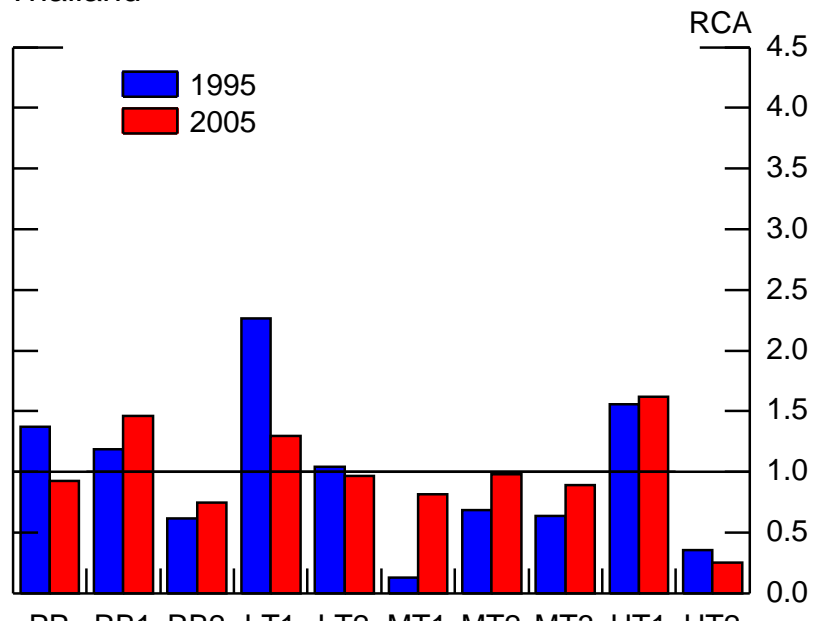

PP RB1 RB2 LT1 LT2 MT1 MT2 MT3 HT1 HT2

India

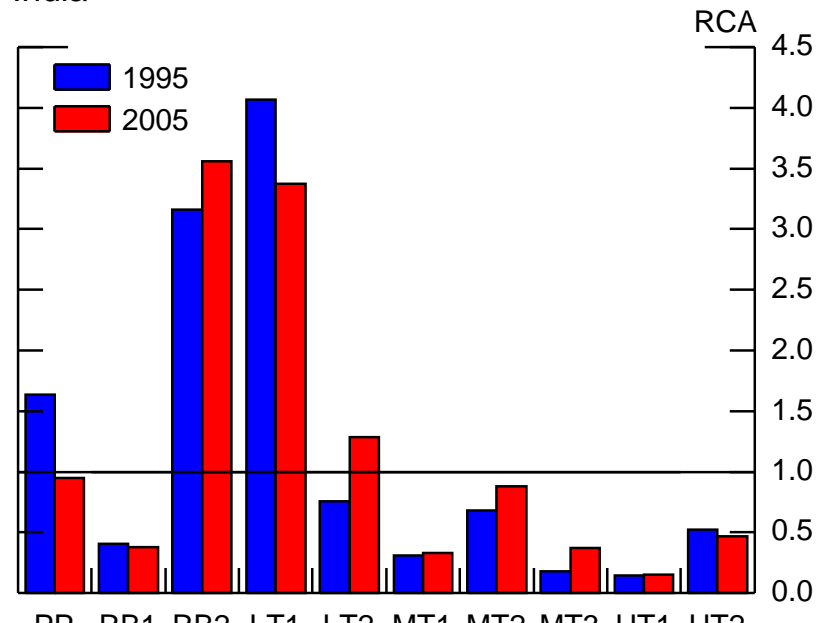

PP RB1 RB2 LT1 LT2 MT1 MT2 MT3 HT1 HT2 


\section{APPENDIX}

\section{DATA SOURCES}

Goods imports and exports are taken directly from the United Nation's COMTRADE database for all countries but Taiwan. The interactive software for United Nation's COMTRADE allows the user to create country and commodity groups which automatically aggregate for specified goods and countries. Data for Taiwan was downloaded from SourceOECD using the site's interactive system. All commodity data presented is SITC Rev.3.

\section{Number of SITC Rev.3 codes}

10 1-digit SITC Rev.3 commodity codes.

261 3-digit SITC Rev.3 commodity codes.

1073 5-digit SITC Rev.3 commodity codes identified as parts and components.

763 5-digit SITC Rev.3 commodity codes identified as basic products, resources.

3212 5-digit SITC Rev.3 commodity codes total (not including SITC 9):

PP: 513

RB1: $365 \quad$ RB2: 370

LT1: $324 \quad$ LT2: 440

MT1: $53 \quad$ MT2: $345 \quad$ MT3: 531

HT1: $138 \quad$ HT2: 133

It is important to note that when data was downloaded at the 5-digit level, some 4digit codes were also used. This only occurred when a 4-digit code was not followed by any 5-digit codes. For example, 69421 and 69422 are breakdowns of 6942, however, the nearby commodity code 6941 is not broken down to 5 -digits. So when downloading, we used 6941, 69421 and 69422, but not 6942.

\section{NOTES ON METHODOLOGY}

\section{Technological Categories}

For technological categories, we followed the lead of Sanjaya Lall. Lall broke down SITC Rev.2 commodity codes at the three-digit level into ten technological groups: Primary Products (PP), Agro-based Manufactures (RB1), Other Resource-based Manufactures (RB2), Textile, Garment and Footwear (LT1), Other Low-technology Manufactures (LT2), Automotive (MT1), Process: Chemicals and Basic Metals (MT2), Engineering Products (MT3), Electronics and Electrical (HT1) and Other Hightechnology Goods (HT2). The items of SITC 9 are considered not classifiable. Using Lall's list we were able to correspond from SITC Rev.2 to SITC Rev.3. The list of these commodities along with descriptions can be found in this Appendix. 


\section{Fragmentation Categories}

Goods were separated into basic products, parts and components, and finished goods by examining 5-digit commodity codes. SITC $0,1,3,4$ did not contain any 5 -digit categories that were considered to be parts. SITC 2 had only a few (all of the 5-digit subcategories of SITC 232, 266 and 267). We largely followed Athukorala's paper for SITC 7 and 8. We used our own judgment to separate 5 and 6.

We define parts and components as intermediate goods, i.e. manufactured items which are combined with other items and materials to produce finished goods. Parts and components alone cannot be used as a finished good a majority of the time, but there are always exceptions to this. Finished goods, on the other hand, are all other goods requiring little or no processing before becoming consumable.

Our "Other" category consists of basic products, natural resources, food and beverages, etc. Similarly, construction materials like railroad tracks, pipes, pipeline, cement, etc and raw materials such as fertilizers are not likely to be manufactured into an exportable, finished good.

Some problems arise in distinguishing parts and components from finished goods. For example, ball bearings can be purchased by a consumer from a McMaster's catalog, but are usually purchased by industrial firms to produce machinery. Other commodities are not so clear-cut: for example 88115 includes photographic flashlight parts and accessories. As this category includes both parts used to manufacture photographic flashlights as well as final goods (accessories) purchased to complement a photographic flashlight, classifying it is difficult. In these situations, we consider what portion of the total value of the category likely consists of parts and components. If over half, then the commodity is classified as a part and component. Occasionally our search was aided by the word "parts" or "pts" in the commodity description, but this was not always the case. Another good method to distinguish parts from finished goods was to look at how a category is related to neighboring SITC codes. If the category in which we were interested contained parts of goods in nearby commodity codes, then the code could easily be classified as a part and component, otherwise the answer is more ambiguous. The process was far from perfect and leaves some room for refinement. 


\section{3-DIGIT PRODUCTS BY TECHNOLOGICAL CATEGORY: (SITC REV.3)}

$\begin{array}{llll}\text { (PP) } & \text { Primary Products: } & & \\ 001 & \text { LIVE ANIMALS EXCEPT FISH } & 244 & \text { CORK NATURAL/RAW/WASTE } \\ 011 & \text { BEEF, FRESH/CHILLD/FROZN } & 245 & \text { FUEL WOOD/WOOD CHARCOAL } \\ 022 & \text { MILK PR EXC BUTTR/CHEESE } & 246 & \text { WOOD CHIPS/WASTE } \\ 025 & \text { EGGS, ALBUMIN } & 261 & \text { SILK } \\ 034 & \text { FISH,LIVE/FRSH/CHLD/FROZ } & 263 & \text { COTTON } \\ 036 & \text { CRUSTACEANS MOLLUSCS ETC } & 268 & \text { WOOL/ANIMAL HAIR } \\ 041 & \text { WHEAT/MESLIN } & 272 & \text { FERTILIZERS CRUDE } \\ 042 & \text { RICE } & 273 & \text { STONE/SAND/GRAVEL } \\ 043 & \text { BARLEY GRAIN } & 274 & \text { SULPHUR/UNROASTD PYRITES } \\ 044 & \text { MAIZE EXCEPT SWEET CORN. } & 277 & \text { NATURAL ABRASIVES N.E.S. } \\ 045 & \text { CEREAL GRAINS NES } & 278 & \text { OTHER CRUDE MINERALS } \\ 054 & \text { VEGETABLES,FRSH/CHLD/FRZ } & 291 & \text { CRUDE ANIMAL MTERIAL NES } \\ 057 & \text { FRUIT/NUTS, FRESH/DRIED } & 292 & \text { CRUDE VEG MATERIALS NES } \\ 071 & \text { COFFEE/COFFEE SUBSTITUTE } & 321 & \text { COAL NON-AGGLOMERATED } \\ 072 & \text { COCOA } & 333 & \text { PETROL./BITUM. OIL,CRUDE } \\ 074 & \text { TEA AND MATE } & 342 & \text { LIQUID PROPANE/BUTANE } \\ 075 & \text { SPICES } & 343 & \text { NATURAL GAS } \\ 081 & \text { ANIMAL FEED EX UNML CER. } & 344 & \text { PETROL./HYDROCARBON GAS } \\ 091 & \text { MARGARINE/SHORTENING } & 345 & \text { COAL GAS/WATER GAS/ETC } \\ 121 & \text { TOBACCO, RAW AND WASTES } & 351 & \text { ELECTRIC CURRENT } \\ 211 & \text { HIDE/SKIN (EX FUR) RAW } & 681 & \text { SILVER/PLATINUM ETC } \\ 212 & \text { FURSKINS/PIECES, RAW } & 682 & \text { COPPER } \\ 222 & \text { OIL SEEDS ETC - SOFT OIL } & 683 & \text { NICKEL } \\ 223 & \text { OIL SEEDS-NOT SOFT OIL } & 684 & \text { ALUMINIUM } \\ 231 & \text { NATURAL RUBBER/LATEX/ETC } & 685 & \text { LEAD } \\ & & 686 & \text { ZINC } \\ & & 687 & \text { TIN }\end{array}$


(RB1) Agro-based Manufactures:

$\begin{array}{ll}012 & \text { MEAT NES,FRESH/CHLD/FROZ } \\ 016 & \text { MEAT/OFFAL PRESERVED } \\ 017 & \text { MEAT/OFFAL PRESVD N.E.S } \\ 023 & \text { BUTTER AND CHEESE } \\ 024 & \text { CHEESE AND CURD } \\ 035 & \text { FISH,DRIED/SALTED/SMOKED } \\ 037 & \text { FISH/SHELLFISH,PREP/PRES } \\ 046 & \text { FLOUR/MEAL WHEAT/MESLIN } \\ 047 & \text { CEREAL MEAL/FLOUR N.E.S } \\ 048 & \text { CEREAL ETC FLOUR/STARCH } \\ 056 & \text { VEG ROOT/TUBER PREP/PRES } \\ 058 & \text { FRUIT PRESVD/FRUIT PREPS } \\ 059 & \text { FRUIT/VEG JUICES } \\ 061 & \text { SUGAR/MOLLASSES/HONEY } \\ 062 & \text { SUGAR CONFECTIONERY } \\ 073 & \text { CHOCOLATE/COCOA PREPS } \\ 098 & \text { EDIBLE PRODUCTS N.E.S. } \\ 111 & \text { BEVERAGE NON-ALCOHOL NES } \\ 112 & \text { ALCOHOLIC BEVERAGES } \\ 122 & \text { TOBACCO, MANUFACTURED } \\ 232 & \text { RUBBER SYNTH/WASTE/ETC } \\ 247 & \text { WOOD IN ROUGH/SQUARED } \\ 248 & \text { WOOD SIMPLY WORKED } \\ 251 & \text { PULP AND WASTE PAPER } \\ 264 & \text { JUTE/BAST FIBRE RAW/RETD } \\ 265 & \text { VEG TEXT FIBRE EX COT/JU } \\ 269 & \text { WORN CLOTHING ETC } \\ 421 & \text { FIXED VEG OIL/FAT, SOFT } \\ 422 & \text { FIXED VEG OILS NOT SOFT } \\ 431 & \text { ANIMAL/VEG OILS PROCES'D } \\ 621 & \text { MATERIALS OF RUBBER } \\ 625 & \text { RUBBER TYRES/TREADS } \\ 629 & \text { ARTICLES OF RUBBER NES } \\ 633 & \text { CORK MANUFACTURES } \\ 634 & \text { VENEER/PLYWOOD/ETC } \\ & \end{array}$

635 WOOD MANUFACTURES N.E.S.

641 PAPER/PAPERBOARD

(RB2) Other Resource-based:

281 IRON ORE/CONCENTRATES

282 FERROUS WASTE/SCRAP

283 COPPER ORES/CONCENTRATES

284 NICKEL ORES/CONCS/ETC

285 ALUMINIUM ORES/CONCS/ETC

286 URANIUM/THORIUM ORE/CONC

287 BASE METAL ORE/CONC NES

288 NF BASE METAL WASTE NES

289 PRECIOUS METAL ORE/CONC.

322 BRIQUETTES/LIGNITE/PEAT

325 COKE/SEMI-COKE/RETORT C

334 HEAVY PETROL/BITUM OILS

335 RESIDUAL PETROL. PRODS

411 ANIMAL OIL/FAT

511 HYDROCARBONS/DERIVATIVES

514 NITROGEN FUNCTION COMPDS

515 ORGANO-INORGANIC COMPNDS

516 OTHER ORGANIC COMPOUNDS

522 ELEMENTS/OXIDES/HAL SALT

523 METAL SALTS OF INORG ACD

524 METAL SALTS OF INORG ACD

531 SYNTH ORG COLOUR AGENTS

532 DYEING/TANNING EXTRACTS

551 ESSENT.OIL/PERFUME/FLAVR

592 STARCHES/GLUES/ETC.

661 LIME/CEMENT/CONSTR MAT'L

662 CLAY/REFRACTORY MATERIAL

663 MINERAL MANUFACTURES NES

664 GLASS

667 PEARLS/PRECIOUS STONES

689 MISC NON-FERR BASE METAL 
(LT1) Textile, Garment, and Footwear:

$\begin{array}{ll}611 & \text { LEATHER } \\ 612 & \text { LEATHER MANUFACTURES } \\ 613 & \text { FURSKINS TANNED/DRESSED } \\ 651 & \text { TEXTILE YARN } \\ 652 & \text { COTTON FABRICS, WOVEN } \\ 654 & \text { WOVEN TEXTILE FABRIC NES } \\ 655 & \text { KNIT/CROCHET FABRICS } \\ 656 & \text { TULLE/LACE/EMBR/TRIM ETC } \\ 657 & \text { SPECIAL YARNS/FABRICS } \\ 658 & \text { MADE-UP TEXTILE ARTICLES } \\ 659 & \text { FLOOR COVERINGS ETC. } \\ 831 & \text { TRUNKS AND CASES } \\ 841 & \text { MENS/BOYS WEAR, WOVEN } \\ 842 & \text { WOMEN/GIRL CLOTHING WVEN } \\ 843 & \text { MEN/BOY WEAR KNIT/CROCH } \\ 844 & \text { WOMEN/GIRL WEAR KNIT/CRO } \\ 845 & \text { ARTICLES OF APPAREL NES } \\ 846 & \text { CLOTHING ACCESSORIES } \\ 848 & \text { HEADGEAR/NON-TEXT CLOTHG } \\ 851 & \text { FOOTWEAR }\end{array}$

\section{(LT2) Other Low-tech Manufactures:}

$\begin{array}{ll}642 & \text { CUT PAPER/BOARD/ARTICLES } \\ 665 & \text { GLASSWARE } \\ 666 & \text { POTTERY } \\ 673 & \text { FLAT ROLLED IRON/ST PROD } \\ 674 & \text { ROLLED PLATED M-STEEL } \\ 675 & \text { FLAT ROLLED ALLOY STEEL } \\ 676 & \text { IRON/STEEL BARS/RODS/ETC } \\ 677 & \text { IRON/STEEL RAILWAY MATL } \\ 678 & \text { IRON/STEEL WIRE } \\ 691 & \text { IRON/STL/ALUM STRUCTURES } \\ 692 & \text { METAL STORE/TRANSPT CONT } \\ 693 & \text { WIRE PROD EXC INS ELECTR } \\ 694 & \text { NAILS/SCREWS/NUTS/BOLTS } \\ 695 & \text { HAND/MACHINE TOOLS } \\ 696 & \text { CUTLERY } \\ 697 & \text { BASE METAL H'HOLD EQUIPM } \\ 699 & \text { BASE METAL MANUFAC NES } \\ 811 & \text { PREFABRICATED BUILDINGS } \\ 821 & \text { FURNITURE/STUFF FURNISHG } \\ 892 & \text { PRINTED MATTER } \\ 893 & \text { ARTICLES NES OF PLASTICS } \\ 894 & \text { BABY CARR/TOY/GAME/SPORT } \\ 895 & \text { OFFICE/STATIONERY SUPPLY } \\ 896 & \text { ART/COLLECTIONS/ANTIQUES } \\ 897 & \text { JEWELLERY } \\ 898 & \text { MUSICAL INSTRUMS/RECORDS } \\ 899 & \text { MISC MANUF ARTICLES NES }\end{array}$


(MT1) Automotive:

781 PASSENGER CARS ETC

782 GOODS/SERVICE VEHICLES

783 ROAD MOTOR VEHICLES NES

784 MOTOR VEH PARTS/ACCESS

785 MOTORCYCLES/CYCLES/ETC

(MT2) Chemicals and Basic Metals:

$\begin{array}{ll}266 & \text { SYNTHETIC SPINNING FIBRE } \\ 267 & \text { MAN-MADE FIBRES NES/WAST } \\ 512 & \text { ALCOHOLS/PHENOLS/DERIVS } \\ 513 & \text { CARBOXYLIC ACID COMPOUND } \\ 533 & \text { PIGMENTS/PAINTS/VARNISH } \\ 553 & \text { PERFUME/TOILET/COSMETICS } \\ 554 & \text { SOAPS/CLEANSERS/POLISHES } \\ 562 & \text { MANUFACTURED FERTILIZERS } \\ 571 & \text { PRIMARY ETHYLENE POLYMER } \\ 572 & \text { STYRENE PRIMARY POLYMERS } \\ 573 & \text { VINYL CHLORIDE ETC POLYM } \\ 574 & \text { POLYACETALS/POLYESTERS. } \\ 575 & \text { PLASTIC NES-PRIMARY FORM } \\ 579 & \text { PLASTIC WASTE/SCRAP } \\ 581 & \text { PLASTIC TUBE/PIPE/HOSE } \\ 582 & \text { PLASTIC SHEETS/FILM/ETC } \\ 583 & \text { MONOFILAMENT RODS/STICKS } \\ 591 & \text { HOUSEHOLD/GARDEN CHEMCAL } \\ 593 & \text { EXPLOSIVES/PYROTECHNICS } \\ 597 & \text { OIL ETC ADDITIVES/FLUIDS } \\ 598 & \text { MISC CHEMICAL PRODS NES } \\ 653 & \text { MAN-MADE WOVEN FABRICS } \\ 671 & \text { PIG IRON ETC FERRO ALLOY } \\ 672 & \text { PRIMARY/PRODS IRON/STEEL } \\ 679 & \text { IRON/STEEL PIPE/TUBE/ETC } \\ 786 & \text { TRAILERS/CARAVANS/ETC } \\ 791 & \text { RAILWAY VEHICLES/EQUIPMT } \\ 882 & \text { PHOTOGRAPHIC SUPPLIES } \\ 883 & \text { CINE FILD DEVELOPED } \\ & \end{array}$

(MT3) Engineering Products:

711 STEAM GENERATING BOILERS

713 INTERNAL COMBUST ENGINES

714 ENGINES NON-ELECTRIC NES

721 AGRIC MACHINE EX TRACTR

722 TRACTORS

723 CIVIL ENGINEERING PLANT

724 TEXTILE/LEATHER MACHINRY

725 PAPER INDUSTRY MACHINERY

726 PRINTING INDUSTRY MACHNY

727 FOOD PROCESSING MACHINES

728 SPECIAL INDUST MACHN NES

731 MACH-TOOLS REMOVE MTRIAL

733 MTL M-TOOLS W/O MTL-RMVL

735 METAL MACHINE TOOL PARTS

737 METALWORKING MACHINE NES

741 INDUST HEAT/COOL EQUIPMT

742 PUMPS FOR LIQUIDS

743 FANS/FILTERS/GAS PUMPS

744 MECHANICAL HANDLING EQUI

745 NON-ELECTR MACHINES NES

746 BALL/ROLLER BEARINGS

747 TAPS/COCKS/VALVES

748 MECH TRANSMISSION EQUMNT

749 NON-ELEC PARTS/ACC MACHN

762 RADIO BROADCAST RECEIVER

763 SOUND/TV RECORDERS ETC

772 ELECTRIC CIRCUIT EQUIPMT

773 ELECTRICAL DISTRIB EQUIP

775 DOMESTIC EQUIPMENT

793 SHIPS/BOATS/ETC

812 SANITARY/PLUMB/HEAT FIXT

813 LIGHTING FIXTURES ETC

872 MEDICAL/ETC INSTRUMENTS

873 METERS AND COUNTERS NES

884 OPTICAL FIBRES

885 WATCHES AND CLOCKS

891 ARMS AND AMMUNITION 
(HT1) Electronics and Electrical:

716 ROTATING ELECTR PLANT

718 POWER GENERATING EQU NES

751 OFFICE MACHINES

752 COMPUTER EQUIPMENT

759 OFFICE EQUIP PARTS/ACCS.

761 TELEVISION RECEIVERS

764 TELECOMMS EQUIPMENT NES

771 ELECT POWER TRANSM EQUIP

774 MEDICAL ETC EL DIAG EQUI

776 VALVES/TRANSISTORS/ETC

778 ELECTRICAL EQUIPMENT NES

\section{(HT2) Other High-tech:}

525 RADIO-ACTIVE ETC MATRIAL

541 PHARMACEUT EXC MEDICAMNT

542 MEDICAMENTS INCLUDE VET

712 STEAM/VAPOUR TURBINES

792 AIRCRAFT/SPACECRAFT/ETC

871 OPTICAL INSTRUMENTS NES

874 MEASURE/CONTROL APP NES

881 PHOTOGRAPHIC EQUIPMENT

\section{Other:}

911 POSTAL PACKETS NOT CLASS

931 SPECIAL TRANSACTIONS NES

961 COIN NONGOLD NON CURRENT

971 GOLD NON-MONETARY EX ORE

\section{1-DIGIT PRODUCTS BY SITC: (SITC REV.3)}

$\begin{array}{ll}0 & \text { FOOD \& LIVE ANIMALS } \\ 1 & \text { BEVERAGES AND TOBACCO } \\ 2 & \text { CRUDE MATER.EX FOOD/FUEL } \\ 3 & \text { MINERAL FUEL/LUBRICANTS } \\ 4 & \text { ANIMAL/VEG OIL/FAT/WAX } \\ 5 & \text { CHEMICALS/PRODUCTS N.E.S } \\ 6 & \text { MANUFACTURED GOODS } \\ 7 & \text { MACHINERY/TRANSP EQUIPMT } \\ 8 & \text { MISCELLANEOUS MANUF ARTS } \\ 9 & \text { COMMODITIES NES }\end{array}$




\section{PRODUCTS BY USE: (SITC REV.3)}

\section{Parts and Components:}

232 RUBBER SYNTH/WASTE/ETC

266 SYNTHETIC SPINNING FIBRE

267 MAN-MADE FIBRES NES/WAST

511 HYDROCARBONS/DERIVATIVES

515 ORGANO-INORGANIC COMPNDS

516 OTHER ORGANIC COMPOUNDS

52 INORGANIC CHEMICALS

531 SYNTH ORG COLOUR AGENTS

532 DYEING/TANNING EXTRACTS

5331 COLORING PREPARATION NES

57 PLASTICS IN PRIMARY FORM

58 PLASTICS NON-PRIMRY FORM

611 LEATHER

613 FURSKINS TANNED/DRESSED

621 MATERIALS OF RUBBER

625 RUBBER TYRES/TREADS

62921 CONVEYOR/ETC BELTS "V"

62929 UH NON-CELL RUB ARTICLES

634 VENEER/PLYWOOD/ETC

6411 NEWSPRINT ROLLS/SHEETS

6412 UNCOATED PAPER/BOARD

6413 PAPER COATED/COLOURD ETC

6414 UNCOATED KRAFT PAPER

6415 KRAFT UNCOAT BULK NES

6416 BULK CORRUG ETC PAPER

6417 BULK PAPER ETC NES

64191 TAR-LAMINATED PAPER ETC. 64192 COMPOSITE PAPER BULK NES 64193 PAPER PULP FILTER BLOCKS

65112 CARDED WOOL YARN IN BULK

65113 COMBED WOOL YARN IN BULK 65115 COARSE HAIR YARN IN BULK 65117 CARDED WOOL BLEND YARN 65118 COMBED WOOL BLEND YARN 65121 COTTON SEWING THRD, BULK 65133 COTTON(>85\%)YARN BULK 65134 COTTON(<85\%)YARN BULK 6514 MAN-MADE SEWING THREADS 6515 SYNTH.FIL.YARN TEXT.BULK 65162 NYLON/POLYAM HI-TEN YARN 65163 SINGLE UNTW SYN YARN NES
65164 SINGL TWIST SYN YARN NES 65169 MULTI-FIL SYNTH YARN NES 65172 BULK TEXTURED ARTIF YARN 65173 BULK HI-TEN VISCOS RAYON 65174 BULK VISCO-RAYON $<120 \mathrm{~T} / \mathrm{M}$ 65175 SINGLE ARTIF YARN NES 65176 MULTI-FIL ARTIF YARN NES 65177 ARTIF MONFIL > 67 DECITEX 65182 SYN STAP( $>85 \%)$ YARN BULK 65184 SYN STAP $(<85 \%)$ YARN BULK 65186 ART STAP( $>85 \%)$ YARN BULK 65187 ART STAP $(<85 \%)$ YARN MIXT. 65188 SYN MONOF YARN $>67 D E C I T E X$ 65191 METALLIZED TEXTILE YARN 65192 SILK YARN NON WASTE,BULK 65193 SILK WASTE YARN IN BULK 65195 YARN ETC OF GLASS FIBRE 65196 FLAX YARN

65197 JUTE ETC YARN

65199 VEG FIBRE YARN NES,PAPER 652 COTTON FABRICS, WOVEN 653 MAN-MADE WOVEN FABRICS

654 WOVEN TEXTILE FABRIC NES

655 KNIT/CROCHET FABRICS

656 TULLE/LACE/EMBR/TRIM ETC

657 SPECIAL YARNS/FABRICS

6641 BULK/SCRAP GLASS

6643 DRAWN/BLOWN GLASS SHEETS

6644 FLOAT/POLISHED GLASS SHT

6645 CAST/ROLLED GLASS SHEETS

6647 TEMPR/LAMIN SAFETY GLASS

66481 VEHICLE REAR-VIEW MIRROR

6649 GLASS N.E.S.

667 PEARLS/PRECIOUS STONES

671 PIG IRON ETC FERRO ALLOY

672 PRIMARY/PRODS IRON/STEEL

673 FLAT ROLLED IRON/ST PROD

674 ROLLED PLATED M-STEEL

675 FLAT ROLLED ALLOY STEEL

676 IRON/STEEL BARS/RODS/ETC

678 IRON/STEEL WIRE

68 NON-FERROUS METALS

69129 STRUCTURES, PARTS ALUMNM 
69243 IRN/STL COMP GAS TANKS

69244 ALUMINIUM COMP GAS TANKS

694 NAILS/SCREWS/NUTS/BOLTS

6994 SPRINGS AND LEAVES

7112 AUX PLANT FOR BOILERS

7119 PARTS FOR BOILERS/ETC

7128 STM TURBINE(712.1)PARTS

713 INTERNAL COMBUST ENGINES

714 ENGINES NON-ELECTRIC NES

716 ROTATING ELECTR PLANT

7189 ENGINES/MOTORS NES

71819 PARTS NES HYDRAUL TURBIN

71878 NUCLEAR REACTOR PARTS

72119 AGRIC MACHINE(7211)PARTS

72129 PTS NES OF MACHY OF 7212

72139 PTS NES DAIRY MACHINERY

72198 PARTS WINE/ETC MACHINES

72199 PTS NES AGRIC MACHINES

7239 EARTH MOVING MACH PARTS

72439 SEW MCH NEEDLES/FURN/PTS

72449 PTS NES TEXTILE MACHINES

72467 WEAVING LOOM PARTS/ACCES

72468 LOOM/KNITTER ETC PTS/ACC

72488 PARTS FOR LEATHER MACHNS

7249 WASHING/ETC MACHINE PART

7259 PAPER IND MACHINE PARTS

72689 PTS NES OF BOOKBIND MCHN

72691 TYPE-SETTING MACHN PARTS

72699 PRINTING PRESS PARTS

72719 CEREAL/DRY LEGM MACH PTS

72729 INDUS FOOD PROC MACH PTS

72819 PTS NES OF TOOLS OF 7281

72839 PTS NES OF MACHY OF 7283

7285 PARTS SPEC INDUST MACHNY

7359 METALWORK MACH-TOOL PTS

73719 FOUNDRY MACHINE PARTS

73729 ROLL-MILL PTS NES, ROLLS

73739 MTL WELD/SOLDER EQ PARTS

73749 PARTS GAS WELDERS ETC.

7412 NON-ELEC FURNACES/PARTS

74135 ELECT FURNACE/OVEN PARTS

74139 ELECT FURNACE/OVEN PARTS

74149 PTS NES INDUS REFRIG EQU

74159 AIR-CONDITIONER PARTS

74172 WATER PROC GAS GEN PARTS

7419 PARTS INDUS HEAT/COOL EQ
7422 PISTON ENG FUEL/WTR PUMP

7429 PUMP/LIQ ELEVATOR PARTS

74311 VACUUM PUMPS

74315 REFRIGERATOR COMPRESSORS

74345 FAN COOKER HOODS $<120 \mathrm{CM}$

7435 CENTRIFUGES

7438 PARTS FOR FANS/GAS PUMPS

7439 PARTS CENTRIFUGE/FILTERS

74419 PTS NES OF WORK TRUCKS

7442 PULLEYS/WINCHES/CAPSTANS

7449 LIFT/HANDLE MACHINE PART

74519 PTS NES OF TOOL OF 7451

74529 PACKING ETC MCHY PTS NES

74539 WEIGHNG MACH WTS,PTS NES

74568 SPRAYING MACHINERY PARTS

74593 ROLLING MACHINE PARTS

74597 AUTOMATIC VENDING MACH PTS

746 BALL/ROLLER BEARINGS

747 TAPS/COCKS/VALVES

748 MECH TRANSMISSION EQUMNT

749 NON-ELEC PARTS/ACC MACHN

7523 DIGITAL PROCESSING UNITS

759 OFFICE EQUIP PARTS/ACCS.

7649 TELECOMMS PARTS/ACCESS.

7712 ELECT POWER EQ NES/PARTS

772 ELECTRIC CIRCUIT EQUIPMT

7731 INSULATED WIRE/OPT FIBRE

7732 ELEC INSULATING EQUIPMNT

77423 X-RAY TUBES

77429 X-RAY ETC PARTS/ACCESS.

77549 ELECTR SHAVER/ETC PARTS

77579 PARTS DOM ELECT EQUIPMNT

77589 DOMEST EL-THERM APP PART

776 VALVES/TRANSISTORS/ETC

7781 BATTERIES/ACCUMULATORS

77829 PTS NES OF LAMPS OF 7782

7783 VEHICLE ELECTRIC EQU NES

77848 HAND ELEC-MECH TOOL PART

7786 ELECTRICAL CAPACITORS

77883 ELEC TRAFFIC CONTROL PTS

77885 ELECTRIC ALARM PARTS

77889 ELEC PARTS OF MACHY NES

784 MOTOR VEH PARTS/ACCESS

78535 PARTS/ACCESS MOTORCYCLES

78536 PARTS/ACCES INV CARRIAGE

78537 PARTS, ACCES CYCLES ETC 
78689 TRAILER/SEMI-TRAILER PTS

79199 RAIL/TRAM PARTS NES

7929 AIRCRAFT ETC PARTS

81211 RADIATORS, PARTS THEREOF

81219 PARTS FOR C-HEAT BOILERS

8138 PORTABLE LAMP PARTS

8139 PARTS NES LAMPS/FITTINGS

82111 AIRCRAFT SEATS

82112 MOTOR VEHICLE SEATS

82119 PARTS OF CHAIRS/SEATS

8218 FURNITURE PARTS

84848 PARTS FOR HEADGEAR

87119 BINOC/TELESCOPE PART/ACC

87139 ELECTRON/ETC DIFFR PARTS

87149 MICROSCOPES PARTS/ACCESS

87199 PARTS/ACCESS FOR 8719

8724 MEDICAL FURNITURE, PARTS

87319 GAS/LIQ/ELEC METER PARTS

87329 METER/COUNTER PARTS/ACC.

87412 NAVIGATION INST PART/ACC

87414 SURVEY INSTR PARTS/ACC.

87424 PTS NES OF INST OF 8742

87426 MEAS/CHECK INSTR PART/AC

87439 FLUID INSTRUM PARTS/ACC

87449 PHYS/CHEM ANAL PARTS/ACC

87454 MECH TESTER PARTS/ACCS

87456 THERMOMETER ETC PART/ACC

87469 REGUL/CNTRL INST PART/AC

87479 ELEC/RAD METER PARTS/ACC

8749 INSTRUMENT PART/ACC NES
88114 CAMERA PARTS/ACCESSORIES

88115 FLASHLIGHT PARTS/ACCESS

88123 MOVIE CAMERA PARTS/ACC.

88124 MOVIE PROJECTOR PART/ACC

88134 PHOTO EQUIP NES PART/ACC

88136 PHOTO, CINE LAB EQUIP NE

88422 SPECTACLE FRAME PARTS

8843 OPTICL LENS/PRISM/MIRROR

88591 WATCH CASES, CASE PARTS

88592 WATCH STRAPS/BANDS METAL

88593 WATCH STRAP/BAND NON-MTL

88597 CLOCK CASES, CASE PARTS

88598 CLOCK/WATCH MMNTS UNASS

88599 CLOCK/WATCH PARTS NES

89124 CARTRIDGES/PARTS NES

89129 WAR MUNITIONS/PARTS

89191 PISTOL PARTS/ACCESSORIES

89193 SHOTGUN BARRELS

89195 SHOTGUN/RIFLE PARTS NES

89199 MILITARY WEAPON PART NES

8941 BABY CARRIAGES, PARTS NES

89423 DOLL PARTS/ACCESSORIES

8989 MUSICAL INSTR PARTS/ACC.

89935 CIG LIGHTER PARTS/ACCESS

89937 SMOKING PIPES AND PARTS

89949 PARTS NES UMBRELLA/CANES

89984 BUTTON MOULDS/PARTS

89986 SLIDE FASTENER PARTS

89996 PARACHUTES/PARTS/ACCESS.

89997 VACUUM FLASKS/ETC 
Basic Goods, Food and Beverages, Natural Resources, etc:

$\begin{array}{ll}0 & \text { FOOD \& LIVE ANIMALS } \\ 1 & \text { BEVERAGES AND TOBACCO } \\ 21 & \text { HIDE/SKIN/FUR, RAW } \\ 22 & \text { OIL SEEDS/OIL FRUITS } \\ 231 & \text { NATURAL RUBBER/LATEX/ETC } \\ 24 & \text { CORK AND WOOD } \\ 25 & \text { PULP AND WASTE PAPER } \\ 261 & \text { SILK } \\ 263 & \text { COTTON } \\ 264 & \text { JUTE/BAST FIBRE RAW/RETD } \\ 265 & \text { VEG TEXT FIBRE EX COT/JU } \\ 268 & \text { WOOL/ANIMAL HAIR } \\ 269 & \text { WORN CLOTHING ETC } \\ 27 & \text { CRUDE FERTILIZER/MINERAL } \\ 28 & \text { METAL ORES/METAL SCRAP } \\ 29 & \text { CRUDE ANIM/VEG MATER NES } \\ 3 & \text { MINERAL FUEL/LUBRICANTS } \\ 4 & \text { ANIMAL/VEG OIL/FAT/WAX } \\ 56 & \text { MANUFACTURED FERTILIZERS } \\ 661 & \text { LIME/CEMENT/CONSTR MAT'L } \\ 662 & \text { CLAY/REFRACTORY MATERIAL } \\ 663 & \text { MINERAL MANUFACTURES NES } \\ 677 & \text { IRON/STEEL RAILWAY MATL }\end{array}$

\section{Finished Goods:}

All other commodity codes not elsewhere specified (n.e.s.) 